atha varṣeśādivicārādhyāyaḥ | tatra varșeśanirṇayo munthājñānaṃ vinā na bhavaty ata ādau muthahā nirūpyate | tatra munthāśabdasya vyākhyānam āha yādavaḥ |

prasūtilagnabhramaṇena bhāvān mathnāti muntheti ca rūạhir asyāḥ | śubhāśubhākhyaṃ ca phalaṃ vyanakti sthānāśrayād eva vadāmi samyak \|

muthahotpattiprakāram āha samarasiṃhahạ |

janmagatavarșarāśau dvādaśabhakte taduddhṛte śeșe | lagnād gaṇite yatra ca viśrāmyati munthahā sā syāt || iti |

ayam arthah | janmato gatavarșasamūhe dvādaśabhakte śeșo janmalagnād yatra dhanasahajādibhāve viśrāmaṃ prāpnoti sa eva muthahā syāt $\mid$ janma10 cakre pratyabdam ekarāśibhramaṇavaśād yatra yatra rāśyādibhāvaṃ yāti sa bhāva eva varṣe muthahā syād iti | taț̣īkākṛt tejaḥsiṃho 'pi |

1 munthājñānaṃ] muṃjñāthānaṃ $\mathrm{N} \quad 2$ munthāśabdasya] muṃthābdaśasya $\mathrm{N} \quad 3$ yādavaḥ] yādayaḥ $\mathrm{N} \quad 4$ rūḍhir] rūr B $\quad 5$ śubhāśubhākhyaṃ] śubhākhyaṃ $\mathrm{N} \quad 9$ samūhe] samūho G || śeșo] scripsi; śeșe B N G K T M 10 syāt] syād iti K T M 11 yatra $^{2}$ ] om. B K M || yāti] yāli N 12 bhāva] om. G || varṣe] om. G \| taț̣ịāa] tadṛkā B; tadakā N

4-5 prasūti ... samyak] TYS 8.1 $\quad 7-8$ janma ... syāt] Cf. HS 241 


\section{The Ruler of the Year and Related Matters}

\subsection{Calculating the Munthahā}

Now, the chapter on judging the ruler of the year and so on. On that matter, determining the ruler of the year is not possible without understanding the munthahā; therefore, the munthahā is described first. Concerning that, Yādava gives an explanation of the word munthā [in Täjikayogasudhānidhi $8.1]:^{1}$

By rotating the ascendant of the nativity, it churns the houses; therefore it is commonly known as muntha.$^{2}$ It reveals the results known as good or evil by lodging in [different] places. I [shall] describe [it] in full.

[In the Täjikaśāstra], Samarasiṃha states the method of arriving at the munthahā:

Dividing the total years elapsed from the nativity by twelve, taking the remainder and counting from the ascendant, [the sign] where it finds rest will be the munthahā.

The meaning is as follows: dividing the sum of years elapsed from the nativity by twelve, that house [counted] from the ascendant of the nativity - the second, third and so on - in which the remainder comes to rest, will itself be the munthahā. Whatever house, in signs and so on, it reaches by rotation [at a rate of] one sign per year in the figure of the nativity, that house itself will be the munthahā in [that] year. Likewise, his commentator Tejahsimha [states in Daivajñālaṃkrti 13.1]:

1 Balabhadra and the authors he quotes indiscriminately employ the forms $m u[n]$ tha , $m u[n]$ thahā and $i[n]$ thā, $i[n]$ thiha $\left(\right.$ from Arabic al-muntaha $\bar{a}$, al-intih $\bar{a}^{\prime}$ ), with variants, to refer to the profected ascendant. In the translation this nomenclature has generally been standardized as munthahā and inthihā, respectively. See the Introduction.

2 The Sanskrit word for 'churn' is manth-. 
janmodayādinikhile khalu bhāvacakre

pratyabdam ekabhavanam muthahā bhunakti | iti |

vāmano'pi |

janmalagnajarāśyādirāśicakre prajāyate |

pratyabdam muthahā rāśį̣ || iti |

manittho'pi |

dvicandrabhaktāś ca gatābdapiṇ̣̂āh śeșenthihā syād atha janmalagnāt | bhrameña yuktā muthahā purānaị śubhāśubhasyāpi nirūpaṇāya \|

tājikatilake'pi |

aśeșajanmodayapūrvabhāvacakre 'nthihaikam bhavanam bhunakti| iti |

etat spașțaṃ gaṇitapūrvakam uktaṃ tājikamuktāvalyām |

saikā gatābdā vihrtāh patangais

taccheșabhāve muthahā janurbhāt |

bhāvāntarāmiśärkalavo 'numāsam

vṛdhir bhaven māsaphalārtham asyāh $\|$

yā munthahāyāh khalu māsabhuktir

gataisyamāsāntaravāsarais tām |

bhajed avāptim prativāram asyā

vịddhir bhaved ghasraphalārtham evam || iti |

2 pratyabdam] pratyekam K M || eka] eva B; eca N 4 lagnaja] lagna B N || prajāyate] ca jāyate $\mathrm{G} \quad 7$ gatābda] gajābda $\mathrm{G} \quad 8$ nirūpaṇāya] nirūpaṇa ca B N 10 bhavanaṃ] bhuvanaṃ N \| iti] om. B N T K $\quad 11$ uktaṃ] tājikamuktan add. K $\quad 12$ vihṛtāḥ] vihatāḥ G 14 bhāvāntarāṃśārka] bhāvāntarāśyarka M $\quad 15$ vṛddhir] bhuktir G T M $\quad 16$ yā] yān M $\quad 17$ māsāntara] māntara K 18 bhajed] bhaved K T M \| avāptiṃ] avāptaṃ G K T M

1-2 janmo- ... bhunakti] DA 16.1 7-8 dvi ... nirūpanāya] VPh 6-7; cf. HS $31 \quad$ 12-19 saikā ... evam] TMṬ $4.1-2$ 
In the entire circle of houses beginning with the ascendant of the nativity, the munthaha traverses one house every year.

Likewise, Vāmana [states]:

The sign [known as] the munthahā is produced year by year in the circle of signs beginning with the sign of the ascendant of the nativity.

Likewise, Mạ̣ittha [states in Varșaphala 6-7]:

The total of elapsed years is divided by twelve; the remainder [counted] from the ascendant of the nativity is the inthiha $\overline{\text {. The }}$ munthaha $\bar{a}$ was employed by the ancients through rotation for determining good and evil [results].

Likewise, in Täjikatilaka [it is said]:

In the entire circle of houses beginning with the ascendant of the nativ-

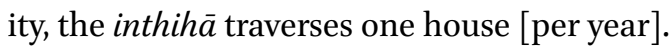

This is clearly described in Täjikamuktāvali[țippaṇi 4.1-2], accompanied by calculations:

Adding one to the elapsed years and dividing them by twelve, the munthah $\bar{a}$ [falls] in the house of the remainder, [counting inclusively] from the sign [rising] in the nativity. Dividing the degrees comprising a house by twelve gives its monthly increment for the sake of [predicting] the results of a month. Similarly, one should divide the monthly motion of the munthahā by the days comprising elapsed and future months; the quotient is its daily increment for the sake of [predicting] the results of a day. 
prasūtilagnabhramaṇena bhāvān mathnāti iti yad avadad yādavo 'py anukūlam | kecana sarvatra janmalagnāṃśayojanaṃ kurvanti | tat pūrvoktavākyānāṃ vicāreṇa yuktisaham | ata eva

svajanmalagnāt prativarșam ekaikarāśibhogān muthahābhrameṇa

iti padyārdhena śrīmannīlakaṇṭhadaivajñaiḥ sāmānyatạ̣ svamatam abhidhāya

svajanmalagnam ravitaștayātaśaradyutaṃ sā bhamukhenthihā syāt

iti ślokottarārdhena tājikasārakartṛmatam abhihitam | tad yathā |

yātābdasaṃghād ravibhir vibhaktāc cheșenthihā syād atha janmalagnāt | janmāñgabhāgaị sahitā || iti |

athavā lagnāṃśayojanaṃ dhanasahajādibhāvāṃśayojanopalakṣakam | yathā janmalagnam sị̣ho dvādaśāṃśamitạ prathamavarṣe tatraiva muthahā | punar dhanabhāvaḥ kanyāyāṃ daśāṃśamitah dvitīyavarșe kanyāyāṃ daśāṃśamitā muthahā | evaṃ sarvatra jñeyaṃ ||

\footnotetext{
1 bhāvān] vān N || mathnāti iti yad avadad] scripsi; mathnātìty avaṃdan B; mathnātīty avadan N K T; mathnātity avadan G; manthātīty avadan M $\quad$ 1-2 anukūlam] scripsi; anukūlah B N G K T M 2 tat] sat B N 4 svajanma] sajanma N; svanma T 7 yāta] jātarā G; pāta M \| sā bha] sāma N 12 tatraiva] tatrai G 13 daśāṃśa] dvādaśāmuśa B N \| mitaḥ] miteh G 14 daśāṃśa] dvādaśāṃśa B N $\|$ mitā] mithā G

1 prasūti ... mathnāti] TYS $8.1 \quad 4$ sva ... bhrameṇa] ST 1.66; VT $2.1 \quad 7$ sva ... syāt] ST 1.66; VT 2.1 9-10 yātābda ... sahitā] TS 126
} 
What Yãdava said - 'By rotating the ascendant of the nativity, it churns the houses' - is agreeable. Some people always add the degree of the ascendant of the nativity [to the munthahä; and] on consideration of the statements above, that is appropriate. Therefore, the illustrious Nilakanțha Daivajña, having set forth his own view in general terms in half a verse [in Samjñātantra 1.66 and Varșatantra 2.1]:

By rotation of the munthaha at the rate of one sign per year from the ascendant of one's nativity -

- in the latter half of the stanza sets forth the view of the author of the Tājikasāra:

- the ascendant of one's nativity, added to the years elapsed reduced by multiples of twelve, is the inthihā in signs and so on.

That [opinion, found in Tājikasāra 126], is as follows:

From the total years elapsed divided by twelve, the remainder [counted] from the ascendant of the nativity is the inthiha, added to the degrees of the ascendant of the nativity ...

Or else, the addition of the degrees of the ascendant is used elliptically for the addition of the degrees of the second, third, and other houses. For example, [if] the birth ascendant is Leo at twelve degrees, that is where the munthah $\bar{a}$ is for the first year; next, the second house is in Virgo at ten degrees; [therefore], in the second year the munthaha $\bar{a}$ is in Virgo at ten degrees. It should be understood in this way in every [house]. 
atha muthahāvicāraṇaprakāraḥ | muthaheśamuthahayoḥ śubham aśubhaṃ vā phalam uktam samarasiṃhena|

kasmin rāśau muthahā kah khețas tatra ko 'dhipas tasyāḥ|

janmani varșe tadbalam anveșyam hinam adhikam vā $\|$

muthahādhipatih șașțhāștamago dvādaśagaś caturthagaś ca |

astamito vakrī vā krūradŕśā vīkșito yutạ krūraị ||

krūrāc caturthasaptamasaṃsthah krūreṇa vā vijitạ̣ |

bhavyo na bhavati varșe cāștamabhavanädhipena yugdrșțah|

krūradrśā maranasamam kaștam yogadvayena maraṇakarah \|

yadi muthaheśo 'ṣțamabhāvādhipena yutạ̣ krūradṛsțyā vā dṛșțas tadā maraṇasamaṃ kașțam | yadi muthahādhipatị șașțhāștamagaḥ ityādyuktalakṣaṇayuto 'șțamādhīśayutadṛștaś ca muthaheśo bhavati tadā maraṇaṃ syāt | atra muthahādhīśadaśāyām așțamādhīśāntardaśā yasmin kāle samāyāti tatraiva maraṇaṃ vācyam | tājikasāre |

munthādhipo vyayavināśagato viviryo

duștagrahas tv aśubhavargagato 'bdakāle |

kaștam nụnām parikaroti bhayam vivādam

lokais tathā nijajanaị kalaham nitāntam \|

tejaḥsiṃhạ̣|

muthahādhipatị șașthāșțamāntyāstagato 'stagaḥ|

vakro vā nijadhātüttharyādhiṃ dadyād daśāsu ca \|

\begin{abstract}
1 prakārah] s scripsi; prakāra B N; prakāram G K T M 5 șașṭhāṣtamago] ṣașṭhoștago B N; șașṭhoșamago G || caturthagaś] scripsi; caturthaś B N G K T M 6 vakrī vā krūra] vakrūra G 7 krūrāc] krūrāś M || vijitaḥ] vivarjjitaḥ G 8 cāșțama] vāșțama K T M || bhavanādhipena] bhavanādhipe B; bhāvanādhipena G $\quad 10$ dṛsțtyā vā] om. K M $\quad 13$ atra] atha G T $\quad 15$ munthādhipo] muthahādhipo B N 17 kașțaṃ] kalaṣțam G \|| bhayaṃ vivādaṃ] bhavaṃti vādaṃ B N
\end{abstract}

15-18 munthā- ... nitāntam] TS 188

2O-21 muthahā- ... ca] This stanza is not found in independent text witnesses of the DA.

3 Most likely a misattribution. The stanza is very similar to that attributed (also, most probably, wrongly) to Samarasimha almost immediately below; cf. note 5 . 


\subsection{General Results of the Munthaha}

Next, the method of judging the munthahā. The good or evil results of the munthahā and the ruler of the munthahā are described by Samarasimpha [in the Tājikaśāstra]:

In which sign is the munthahā? What planet is there? Who is the ruler of that [munthahā]? Its strength should be examined in the nativity [and] in the year, whether [it is] small or great. The ruler of the munthahā in the sixth or eighth, twelfth or fourth [house], [heliacally] set or retrograde, aspected with a malefic aspect [by, or] joined to, malefics, occupying the fourth or seventh [sign] from a malefic or vanquished by a malefic, is not auspicious in [that] year, nor if joined to or aspected by the ruler of the eighth house. By a malefic aspect [one suffers] evil equal to death; by two [such] configurations, it kills.

If the ruler of the munthahā is joined to or aspected by the ruler of the eighth house with an evil aspect, then there is evil equal to death. If the ruler of the munthahā possesses the characteristics described in [the verse] beginning 'The ruler of the munthahā in the sixth or eighth' and is also joined to or aspected by the ruler of the eighth, then death will occur. Here death should be predicted at the time when the subperiod of the ruler of the eighth [house] occurs in the period of the ruler of the munthahā. [It is said] in Tājikasāra [188]:

The ruler of the munthahā in the twelfth or eighth house, being bereft of strength, a malefic planet, and occupying malefic divisions at the time of [the revolution of] the year, surrounds men with misfortune, danger and arguments with people [in general], and also much quarrel with their own kin.

[And] Tejahsimha [says]:3

The ruler of the munthahā occupying the sixth, eighth, twelfth or seventh house, [heliacally] set or retrograde, will give illness arising from its own element ${ }^{4}$ and in [its own] periods.

4 In a medical context, dhātu 'element' may refer to the three humours of wind ( $v \bar{a} t a)$, bile ( pitta) and phlegm (kapha), normally called doșa, but more often means the seven bodily substances of chyle, blood, flesh, fat, bone, marrow and semen. 
tājikabhūṣaṇe |

bhägye ca lābhe sahaje ca kendre ced varșakāle muthahädhināthaḥ| karoti puṃsām vipulam pratāpam maitram nṛpaị sanmativardhanam ca \|

samarasimhhạ |

muthahādhipatịn kendre svoccamitrasvarāśigah |

karoti vividhārthāptim suhṛtsaukhyam viśeșataḥ ||

ayaṃ dușțamuthahāpavāda iti jīrṇāḥ |

daśame cāye punye svāmitvakarī nṛnām bhaven muthahā | lagnadvitīyapañcamasahaje copakramād dhanam datte $\|$ lagnāt șașțadvādaśacaturthasaptāștagā na varā| saviśeșaṃ tu tadīśe dagdhe śubhasamyute śreșthā $\|$

tanudhanasahajādīnāṃ madhye yatrāsti munthahā tasya pūrvoktajātakaphalaṃ tatkāle yacchati | śubheśāt pratibhāve vakșyamāṇaṃ munthāphalạ̣ śubheśamunthāyāṃ pūrṇaṃ jñeyam | krūreśamunthāyāṃ kiṃcin nyūnaṃ jñeyam ity arthạ ||

3 maitraṃ] maitrīm K T M 5 kendre] om. B $\|$ mitra] mitraḥ B N 7 jīrnāḥ] jīrṇaḥ G K T M 8 cāye] cāpe $\mathrm{M} \|$ puṇye] puṇya B $\|$ karī] kārī B N; karo M \|n ṇ̣āị̣ bhaven] bhaven nụnām K T M 9 lagna] lagnād G 10 saptāșța] saptāṣțama G \| gā] ga B N 12 sahajādīnāṃ] sahajānāṃ B N K T M 13 śubheśāt] śubheśā G K T M 13-14 munthā ... śubheśa] om. B 14 munthāyāṃ²] muṃthādhipatvāt B N

2-3 bhāgye ... ca] TBh 2.2 
[And] in Tājikabhūṣaṇa [2.2 it is said]:

If the ruler of the munthahā is in the ninth, eleventh or third house or in an angle at the time of [the revolution of] the year, it makes abundant prowess for men, friendship with princes, and increase of good thinking.

[And] Samarasimha [says]: ${ }^{5}$

The ruler of the munthahā in an angle, occupying its exaltation, a friendly sign, or its domicile, makes gain of various goods [and] happiness from friends in particular.

Jirṇa states that this is an exception for when [the house placement of] the munthahā is evil:

In the tenth, eleventh or ninth house, the munthahā makes positions of authority for men; and in the ascendant, second, fifth and third house, it gives wealth by [one's own] enterprise. It is not to be desired in the sixth, twelfth, fourth, seventh or eighth [house] from the ascendant, particularly if its ruler is burnt. If [the ruler is] conjunct a benefic, [the munthahā] is very good.

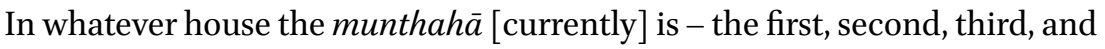
so on - at that time it gives the results predicted for that [house] in the nativity. When the ruler of the munthahā is a benefic, the result of the munthaha about to be declared for each house [as arising] from a benefic ruler should be understood to be full. That is, when the munthaha has a malefic ruler, they should be understood to be somewhat less.

5 Most likely a misattribution; cf. note 3. Unlike all other quotations attributed by Balabhadra to Samarasiṃha (except the single quotation from the Karmaprakāśa), this one is in śloka rather than āryā metre. 
atha muthahāyā dvādaśabhāvaphalāni tejaḥsiṃhenoktāni |

ārogyatām kāyasukhāni pușțịn manahprasādaṃ nrpateh sukhạ̣ ca| pratāpavrddhim vijayam ripūnām kșayam vidhatte muthahā tanusthā || miștâsáanam vittadhanādivṛddhim upakramāc cintitakāryasiddhim | svavargasaṃtoșaṇam ișțavargasamāgamaṃ vittagatenthihāyām || mahodyamam kāyabalapravrddhim ärambhasiddhim ca sahotthasaukhyam | sarvopakartrtvam analpamaitrim tritīyagenthā nrpatiprasādam \| rujām pravrddhim tanupịdanam ca nirudyamatvam ca vapuhkrśatvam | bhayam ripūnām asukhapravrddhiṃ turyenthihā hrdgataguptaduhkham || sadbuddhivrddhiṃ dvijadevabhaktịn pratāpamāhātmyayaśahpravrddhim | sutāptasaukhyam janatāprasādam vittāgamam pañcamagenthihāyām \| ripūdayam caurabhayam kriśatvam nirudyamatvam nrpater bhayạ̣ ca | kāryārthahāniṃ vyasanāgamaṃ ca șașțhenthihā durmatim ișțavairam \| cintām manomoham analparogam pị̂ām kalatrādinijeștakaștam| vittārthanāśạn kumatịn bhayam ca yaśovināśam muthahāstasaṃsthā || duștāmayārtị̣ balakāntināśam amitrabhïtị̣ vyasanāgamạ̣ ca| moham mater bandhanaduhkham arthadharmaprañāsam nidhanasthitenth $\bar{a} \|$ bhāgyodayam dharmadhanārthavrddhim nrpottamaih prîtisamāgamam ca | svavargasaṃtoṣasukhạ̣ yaśaś ca datte 'nthihā bhägyagatārthasiddhim \|

\footnotetext{
1 muthahāyā] muthahāvā K $\quad 2$ ārogyatāṃ] scripsi; ārogyatā B N G K T M 4 mișțāśanaṃ] miṣțānam K 6 bala] balaṃ M 9 nṛpati] nụpa N 10 ca vapuh] vapuṣaḥ G 11 hṛdgata] hṛta K 12 buddhivṛddhiṃ] buddhiṃ $\mathrm{G} \quad 15$ durmatim ișța] durmatinișțha T M $\quad 16$ cintāṃ] scripsi; ciṃtā B N G M; cintā K T \| pīẹāṃ] scripsi; pīẹā B N G K T M 17 kumatị̣] kumatir G $\|$ vināśaṃ] vināśo B N G; vināśạ̣ K T 18 bala] kila B N 20 mohaṃ] mahạ̣ $\mathrm{N} 23$ samāgamaṃ ca] samāgacama $\mathrm{N}$
} 


\subsection{Results of the Munthahā Occupying the Twelve Houses}

Next, the results of the munthahā in the twelve houses are described by Tejạ̣simha: 6

The munthaha in the first house yields good health, pleasures of the body, well-being, contentment of mind, happiness from the king, increase of prowess, victory, and the destruction of enemies.

When the inthih $\bar{a}$ is in the second house [it yields] sweetmeats, increase of wealth, property and so on by enterprise, the realization of planned ventures, the satisfaction of one's own people, and the company of loved ones.

The inthih $\bar{a}$ in the third [house yields] great exertion, increase in physical strength, success in undertakings and happiness from siblings, helpfulness to all, no little friendship, and the favour of kings.

The inthih $\bar{a}$ in the fourth [house yields] increase of illness and pains in the body, lethargy and gauntness of body, danger from enemies, increase of unhappiness, and secret sorrows of the heart.

When the inthih $\bar{a}$ is in the fifth [house it yields] increase of right understanding, devotion to gods and Brahmans, increase of prowess, greatness and renown, happiness from children and intimates, the favour of the community, and the acquisition of wealth.

The inthih $\bar{a}$ in the sixth [house yields] a rise of enemies, danger from robbers, gauntness, lethargy, and danger from the king; frustration of ventures, the onset of calamity, foolishness, and enmity with loved ones.

The munthahā occupying the seventh house [yields] anxiety, bewilderment of mind, no little illness, suffering, misfortunes to one's wife and other loved ones, loss of wealth and property, foolishness, fear, and loss of reputation.

The inthih $\bar{a}$ in the eighth house [yields] suffering from grave illness, loss of strength and beauty, danger from enemies and the onset of calamity, bewilderment of mind, the anguish of imprisonment, and destruction of property and merit.

The inthih $\bar{a}$ occupying the ninth house gives a dawning of good fortune, increase of merit, wealth and property, the favour and company

6 This lengthy passage is not attested in available independent witnesses of Tejaḥsiṃha's Daivajñälaṃkrti. 
nrpaprasādam svajanaiś ca saukhyam mahatpratișthām svajanopakāram| dharmārthaläbham vimalaṃ yaśaś ca vaśitvasaukhyam daśamenthihāyām \| manorathāptim śubhabuddhivrddhim

sutāptasaukhyam svajanaiś ca saukhyam |

dharmārthaläbham manasah prasādam vaśitvam aiśyam muthahāyasaṃsthā anekarukpịdanam añgakārśyam nirudyamatvam svaparair vivādam | dharmārthahāniṃ ripurājabhïtim abhișțapịdām muthahā vyayasthā $\|$ ye rāśayah krürayutās tathā tadastasthitās tatra gatenthihā sā| taddhātujaṃ pịdanam atra bhāvodbhavasya nāsam ca phalasya vindyāt || tanvādibhāve muthahāstiyatra tadbhāvatadvargabhavam phalam tad̄̄| bhavyāśubham vīryavaśena datte vïryam tato 'syāś ca vibhor vicintayet || iti |

atha varṣatantre muthahāyā dvādaśabhāvaphalāni |

śatrukșayam mānasatuștilābham pratāpavṛddhiṃ nrpateḥ prasādam| śarīrapuștịn vividhodyamāmśs ca dadāti saukhyam muthahā tanusthā $\|$ utsāhato 'rthāgamanam yaśaś ca svabandhusanmānanrpāśrayāś ca| miștānnabhogo balapușțisaukhyam syād arthabhāve muthahā yadābde \|

3 ca] vaśiś ca add. $\mathrm{K} \quad 5$ buddhivṛddhiṃ] buddhivṛddhir $\mathrm{N}$; buddhiṃ K; buddhiprāptim T; buddhivāptiṃ M $\quad 8$ vaśitvam] śivatvam G T $\quad 9$ svaparair] tv aparair $\mathrm{G} \quad 11$ tathā tad] tathāvad M || asta] aṃta K T M 13 tanvādi] tatamvādi N 15 muthahāyā] muthahāyāṃ B N

16-436.20 śatru ... vairam] VT 2.5-16 
of great princes, satisfaction and joy among one's own people, and renown.

When the inthiha is in the tenth [house it gives] the favour of the king and happiness with one's own people, great eminence, the assistance of one's own people, gain of merit and property, an unblemished reputation, and the pleasures of power.

The munthahā occupying the eleventh [house gives] fulfilment of wishes, increase of good understanding, happiness from children and intimates and happiness with one's own people, the gain of merit and property, contentment of mind, power and rulership.

The munthaha occupying the twelfth [house gives] the torment of many illnesses, gauntness of body, lethargy, quarrels [both] with one's own [kin] and others, loss of merit and property, danger from enemies and kings, and suffering to loved ones.

[If] the inthih $\bar{a}$ occupies [any of] those signs which are occupied by malefics or [which are] placed opposite ${ }^{7}$ [them, the native] suffers pain arising from that [planet's corresponding] element and destruction of the [good] results produced by the house [located] there. In whatever house the munthaha $\bar{a}$ is, beginning with the ascendant, at that time it gives the good or evil results arising from that house and its divisions ${ }^{8}$ according to its strength; and one should judge its strength from its ruler.

Next, the results of the munthaha $\bar{a}$ in the twelve houses [as described] in Varșatantra [2.5-16]:9

The munthaha $\bar{a}$ in the first house gives destruction of enemies, gain of contentment of mind, increase in prowess, the favour of the king, bodily well-being, a variety of undertakings, and happiness.

In the year when the munthaha $\overline{\text { is in }}$ the second house, there will be acquisition of wealth by exertion, renown, respect from one's own kinsmen and royal patronage, eating of sweetmeats and happiness from growing strength.

7 Text witnesses K T M read 'between'.

8 The meaning of 'divisions' (varga) in this context is not entirely clear, but most probably it refers to the scheme of zodiacal dignities.

9 The similarities between the following astrological delineations and those just attributed to Tejahsiminha are so great that either Nīlakaṇțha must have based his version on that of the earlier author or, perhaps more likely, both versions depend on a still earlier source, presumably Samarasiṃha's Tãjikaśāstra. 
parākramād vittayaśaḥsukhāni saudaryasaukhyaṃ dvijadevapūjā | sarvopakāras tanupușțikāntī nrpāśrayaś cen muthahā tritīye \| śarīrapị̣ā ripubhịh svavargyavairaṃ manastāpanirudyamatve | syān munthahāyām sukhabhāvagāyām janāpavādāmayavrrddhidụ̣kham \| yadīnthihā pañcamagābdaveśe sadbuddhisaukhyātmajavittalābhah | pratāapavrddhir vividhā vilāsā devadvijārcā nrpatiprasādah $\|$ krśatvam añgeșu ripūdayaś ca bhayam rujas taskarato nrpād vā | kāryārthanāśo muthahārigā ced durbuddhivrddhiḥ svakrte 'nutāpaḥ \| kalatrabandhuvyasanāribhītir utsāhabhañgo dhanadharmanāśạ̣| dyūnopagā cen muthahā tanau syād rujā manomohaviruddhaceștā $\|$ bhayam ripos taskarato vināśo dharmārthayor durvyasanāmayāś ca| mrtyusthitā cen muthahā narānāạm balakșayah syād gamanam sudūre \| svāmitvam arthopagamo nrpebhyo dharmotsavah putrakalatrasaukhyam | devadvijjārcā paramam yaśaś ca bhāgyodayo bhāgyagatenthihāyām || nrpaprasādam svajanopakāram satkarmasiddhim dvijadevabhaktim | yaśo'bhivrddhim vividhārthalābham datte 'mbarasthā muthahā padāptim \| yadīnthihā lābhagatā vilāsạ̣ saubhägyanairujyamanahprasādāḥ| bhavanti rājāśrayato dhanāni sanmitraputrābhimatāptayaś ca \| vyayo 'dhiko duștajanaiś ca sañgo rujā tanau vikramato 'py asiddhih | dharmārthahānir muthahā vyayasthā yadā tadā sajjanato 'pi vairam \|

1 saudarya] soṃdarya B; sodarya G; sauṃdarya T M \| saukhyaṃ] khyaṃsau N 2 tṛtīye] scripsi; trtitiyā B G K T M; tṛtīyo N 3 vargya] vargye G; varga KT M \| nirudyamatve] nirudyamatvaṃ T 4 vādāmaya] vādābhaya K T M 5 sadbuddhi] sudbu N 6 nṛpati] nụpatih K T; nụpateh M 8 kṛte] vṛte G 11 durvyasanā-] dravyasanā-K 19 rujā] rujas K T M ॥ vikramato 'py asiddhih] vikramatorthasiddhih B a.c. G; vikramatotha siddhị B p.c.; vikramanothasiddhiḥ N 20 hānir] hānim K T \|| sajjanato] sañjanato T 
If the munthaha is in the third [house], there is wealth, renown and pleasure [resulting] from courageous action, happiness from siblings, veneration of gods and Brahmans, helpfulness to all, bodily well-being and beauty, and royal patronage.

If the munthaha is in the fourth house, there will be pain in the body, danger from enemies, enmity with one's own people, affliction of the mind, lethargy, and suffering from slander by people [in general] and mounting illness.

If the inthih $\bar{a}$ is in the fifth [house] in the revolution of the year, there is gain of right understanding, happiness, children and wealth, increase of prowess, varied delights, veneration of gods and Brahmans, and the favour of the king.

If the munthah $\bar{a}$ is in the sixth house, there is gauntness of the limbs, rise of enemies, danger from illness, robbers, or the king; frustration of ventures, increasing weak-mindedness, and repentance of one's deeds.

If the munthaha is in the seventh house, there will be misfortune to wife and relatives, danger from enemies, frustration of efforts, loss of wealth and merit, illness in the body, and forbidden actions [committed due to] bewilderment of mind.

If the munthah $\bar{a}$ is in the eighth house, there will be danger from enemies and robbers, loss of merit and property, heavy calamities ${ }^{10}$ and illnesses, dwindling of men's strength, and distant journeys.

If the inthih $\bar{a}$ is in the ninth house, there is authority, acquisition of property from princes, religious festivals, happiness from wife and children, veneration of gods and Brahmans, great renown, and the dawning of good fortune.

The munthaha in the tenth house grants the favour of the king, the assistance of one's own people, the accomplishment of good works, devotion to gods and Brahmans, increase in renown, gain of a variety of goods, and the attainment of rank.

If the inthih $\bar{a}$ is in the eleventh house, there is delight, good fortune, good health and contentment of mind, wealth from royal patronage, and the company of good friends, children and loved ones.

When the munthahā is in the twelfth house, there is much expense and association with evil men, illness in the body and failure even after exertion, loss of merit and property, and enmity with good men. 
anyo 'pi viśeșas tatraiva |

krūrair drștah kṣutadrśā yo bhāvo muthahātra cet |

śubham tadbhāvagam naśyed aśubhạ̣ cāpi vardhate \|

vāmanaḥ|

svāminā svāmimitreṇa balạ̣̄yena śubhena vā |

muthahā samyutā drșțā bhāvotthaśubhapoșikā ||

svasvāmiśatrukhețena krūreṇālpabalena vā|

muthahā samyutā drșțā nindyā miśrais tu miśradā $\|$

atra miśrair uttamādhamagrahaiḥ yutadṛșțā munthā sabalagrahasya phaladā bhavati | uktam ca yādavena |

uttamādhamakhagair vimiśritā niścayas tu balaśālino grahāt | iti |

samarasiṃhạ |

janmani madaripumrtyuryayābdhigābde ca tanudhanādisthā |

krūrahatā tadbhāvakșatikrt saumyeśasamyutā śubhadā $\|$

hillājatājike |

janmani ca varșakāle 'nișțasthānasthitā hatā krūraị̣| atyantam aśubhadātrì ubhayatra śubhātisaukhyaṃ syāt || janmacaturthasthāne varșe syād yatra kutrāpi | saumyayutā janakasya ca vasubhūlābhapradātha pāpayutā \|

3 vardhate] vardhateh $\mathrm{G} \quad 5$ balāḍhyena] balādyena N $\quad 6$ poṣikā] poṣikāḥ G $\quad 7$ balena] palena K 9 munthā] muṃthāṃ B; yuṃmunthā N 10 ca] om. B 11 khagair] grahair G || iti] yāt B; syāt N 15 hillāja] hillāje $\mathrm{M} \quad 16$ hatā] hatāḥ N 18 janma] janmani B N 19 janakasya] januṣi śastya B N || pradātha] pradāpa B N

2-3 krūrair ... vardhate] VT $2.17 \quad 11$ uttamā ... grahāt] TYS 8.5 


\subsection{The Munthaha in the Nativity and in the Revolution}

In the same place [Varșatantra 2.17] there is another special rule:

If the munthaha $\bar{a}$ is in a house which is aspected by a malefic with a ksuta aspect, the good of that house will be destroyed, and the evil increases.

[And] Vāmana [says]:

Conjoined to or aspected by its ruler, a friend of the ruler, or a benefic endowed with strength, the munthahā nourishes the good [results] produced by the house [it occupies]. Conjoined to or aspected by a planet inimical to its ruler, or by a malefic of little strength, the munthaha is to be abhorred; [conjoined to or aspected] by mixed [planets], it gives mixed [results].

Concerning this, the munthahā, conjoined to or aspected by mixed, [that is, both] excellent and vile planets, gives the result of the strong[est] planet. And Yādava says [in Tājikayogasudhānidhi 8.5]:

[When the munthahā is] mixed with [both] excellent and vile planets, the judgement derives from the planet possessed of strength.

[And] Samarasiṃha [says in the Tājikaśāstra]:

Occupying the seventh, sixth, eighth, twelfth or fourth house in the nativity and [one of the other houses] - the first, second, and so on in [the revolution of] the year, [the munthahā], afflicted by malefics, effects the destruction of that house; [but] conjoined with benefics [and] its ruler, it gives good [results].

[And] in the Hillājatājika [it is said]:

[The munthahā], occupying a bad place both in the nativity and at the time of [the revolution of] the year and afflicted by malefics, gives utterly evil [results]; [if it is] good in both, there will be great happiness. In the fourth house of the nativity, wherever it falls in the year, [the munthahā] joined to benefics gives gain of goods and land to the 
nrpabhïtikarī mrtyau janmani śubhasaṃyutā varșe | ciravasulābhakarī sā pāpayutā kleśakāriṇī proktā \| evaṃ ca șașthabhāvādiṣu phalam ūhyam svajanmabhataḥ| varșe yasmin bhāve muthahā saumyeśasamyutā bhavati \| evam janmani yah syād bhāvas tadvrddhisaukhyam abde syāt | evam pāpair aśubham janmani yadbhāvagā muthahā pāpair yutā ca drșțā varșe yo bhāva eșa syāt | tasya ca nāśo vācyaḥ phalam asyāh svāmipāke syāt || varșe 'py aniștagehasthitātha yadbhāvagā januși | krūrayutā bhāvasya ca nāśakarī śubhayutā śubhadā || muthaheśo muthahā vā janmani yuktekșitā saumyaih | varșasya pūrvabhāge śubham phalam yacchati svakìyam ca \| evam ca varșakāle phalam ca varșottarārdhe syāt | pāpasya drsțtiyoge aśubham phalam eva tatra syāt || muthahāphalam samastaṃ dhiṣaṇācāryeṇa me gaditam \| iti

atha muthahāyā grahasthānayutidṛșțiphalaṃ varṣatantre |

yadīnthihā sūryagṛhe yutā vā sūryena rājyam nṛpasaṃgamaṃ ca | datte guṇānām parabhāgam āptiṃ sthānāntarasyeti phalạ̣ dṛśo 'pi $\|$ parabhāgaṃ paramamaryādām |

2 karī] valaṃ B N 3 janmabhataḥ] janmataḥ B N 4 bhāve] bhāva G; bhaven K T M 5 evaṃ] eșo G K; ca add. B N \| janmani yah] janmapah B N \| tadvṛddhisaukhyam] tadvad asaumyam B N 6 bhāvagā] bhavanagā G 7 eșa] eva B N 8 nāśo] dāśo B N 9 bhāvagā] bhāva K M 10 bhāvasya] scripsi; tadbhāvasya B N G K T M 14 yoge] yo G 15 me] om. K T M 18 para] pața G \| āptim] āsiṃ N

17-18 yadīnthihā ...'pi] VT 2.24 
father,"11 but joined to malefics, it causes danger from the king. In the eighth house of the nativity, [the munthahā], joined to benefics in the year, causes gain of ancient goods; joined to malefics, it is said to cause misery. So too, the results for the sixth and other houses from the sign of one's [ascendant in the] nativity are to be inferred.

In whatever house the munthaha appears in the year, conjoined to benefics [and] its ruler, and likewise whatever house [that] may be in the nativity, in [that] year there will be happiness from the prospering of that [house]. Likewise [there will be] evil [if the munthahā is joined] by malefics. Whatever house in the nativity the munthaha occupies, joined to or aspected by malefics, [and] whatever house this is in the year, the destruction of that [house] is to be predicted. The results of this [munthahā] will occur in the period of its ruler. And in whatever house of the nativity [the munthah $\bar{a}$ ] occupies the domicile of a malefic in the year, joined to malefics, it destroys the house; joined to benefics, it gives good [results].

Joined to or aspected by benefics in the nativity, the munthahā or its ruler gives its own good results in the former part of the year. [If it is] thus at the time of [the revolution of] the year, the [good] results will occur in the latter half of the year. If a malefic joins or aspects, there will be evil results in that [part of the year]. The entire results of the munthahā were declared to me by Dhiṣanāāārya.

\subsection{Planets Influencing the Munthahā}

Next, the results of the munthaha in the places, conjunctions or aspects of the planets [are described] in Varșatantra [2.24-26]:

If the inthih $\bar{a}$ is in the domicile of the sun or joined to the sun, it gives dominion and the company of princes, the highest part of virtues, [and] the attainment of another place. Such, too, is the result of the aspect [of the sun].

'The highest part' [means] the supreme boundary.

11 Or, possibly, 'gain of the father's goods and land'. 
candrena yuktendugṛhe 'tha dṛștendunāpi vā dharmayaśo'bhivrddhim | nairujyasaṃtoṣamatipravrddhim dadāti pāpekșaṇato 'tiduḥkham \| kujena yuktā kujabhe kujena drșțā ca pittoṣnarujam śarīre | śastrābhighātaṃ rudhiraprakopaṃ saurekșitā saurigrhe viśeșāt ||

samarasimhhạ |

bhaume śaninā yukte saviśeșam śanigṛe 'py evam |

budhena śukrena yutekșitāpi tadbhe 'pi vā strīmatiläbhasaukhyam | dharmaṃ yaśaś cāpy atulam vidhatte kaștam ca pāpekșaṇayogatah syāt \|

samarasiṃhaḥ |

sitabudhapade gurudrśā strīmatilābho 'śubhekșaṇāt kaștam |

yutekșitā vā guruṇa guror bhe yadīnthihà putrakalatrasaukhyam | dadāti hemāmbararatnabhogaṃ śubhetthaśâlād iha rājyalābhạ \| śaner gṛhe tena yutekșitā vā yadīnthihā vātarujạ̣ vidhatte | mānakșayaṃ vahnibhayaṃ dhanasya hānị̣ ca jōvekșaṇatạ śubhāptim \| tamomukhe cen muthahā dhanāptim yaśah sukham dharmasamunnatim ca | sitejyayogekșaṇatah padāptim suvarnaratnāmbaralabdhayaś ca \| tatprșțhabhāge na śubhapradā syāt tatpucchagā yad ripubhïtiduḥkham |

1 gṛhe] grahe B 3 pittoṣna] pitoṣțā N \| śarīre] vidhatte G; tanoti K T M 6 bhaume] bhauma B N || saviśeșaṃ] viśeșaṃ B N 10 dṛ́s̄ā] daśā M 12 lābhah] lābham K T M 13 vā yadīnthihā] om. N || vidhatte] vitte K 17 sitejya] sitejye B || yogekṣaṇataḥ] yogakṣaṇatah $\mathrm{N}$

1-4 candreṇa ... viśeșāt] VT 2.25-26 7-8 budhena ... syāt] VT $2.27 \quad 11-18$ yutekșitā ... ca] VT 2.28-30 19-444.1 tat ${ }^{1} \ldots$ nāśah ] VT 2.32 
Joined to the moon, in the moon's domicile, or aspected by the moon, it gives increase of merit and renown, health, contentment, and improvement of mind; [but] if aspected by a malefic, great misery.

Joined to Mars, in the domicile of Mars, or aspected by Mars, [it gives] illnesses of bile and heat in the body, wounds from weapons, and agitation of blood, particularly if [also] aspected by Saturn [or] in the domicile of Saturn.

Samarasiṃha [says in the Tãjikaśāstra]:

Particularly if Mars is joined to Saturn; likewise if in Saturn's domicile.

[Continuing from Varșatantra 2.27:]

[If the munthahā] is joined to or aspected by Mercury [or] Venus, or in their signs, there is happiness from gain of a woman [or] of comprehension. It bestows unequalled renown and merit; but a malefic aspecting or joining will bring evil.

Samarasiṃha [says in the Tājikaśāstra]:

By the aspect of Jupiter on the place of Venus [or] Mercury, [there is] gain of a woman and of comprehension, [respectively]; an aspect from a malefic brings evil.

[Continuing from Varșatantra 2.28-30, 32:]

If the inthiha is joined to or aspected by Jupiter [or] in Jupiter's domicile, it gives happiness from wife and children, enjoyment of gold, clothes and jewels; by itthaśäla with a benefic here, [the native] gains dominion.

If the inthiha is the domicile of Saturn [or] joined to or aspected by him, it yields illness from [the humour of] wind, loss of honour, danger from fire, and loss of wealth; [but] if aspected by Jupiter, attainment of good [results].

If the munthahā is in the mouth of Rāhu, [it gives] acquisition of wealth, renown, happiness and an upsurge of piety; by conjunction or aspect from Venus or Jupiter, attainment of rank and [there is] gain of gold, jewels and clothes. In its back [the munthahā] will not give good results: if [the munthahā is] placed in its tail, there is the misery of dan- 
pāpekṣaṇād arthasukhasya hāniś cej janmanīttham gṛavittanāśạ̣ ||

samarasimho 'pi |

tatpucche muthahāyām āpad duḥkham vipakșaparitāpaḥ|

janmagatāyām evam vittam parahastagam svayam adriśyam ||

rāhumukhādilakṣaṇaṃ varṣatantre |

bhogyā rāhor lavās tasya mukhaṃ prșțham gatā lavāh |

tatah saptamabham puccham vimrśsyeti phalam vadet \|

gatā bhuktāḥ | vāmano 'pi |

rāhor mukhaṃ bhogyalavās tu bhuktāh

prșțam tathā saptamakam tu puccham | iti |

atra yo graho janmani yasmin rāśau sthito varṣe 'pi tadrāśigatah syāt tadā munthāyutidṛ̦̣̦iphalaṃ pūrṇaṃ prayacchatīti yādavah | tejaḥsiṃhena muthahāyā grahāṇāṃ yogaphalam evoktam |

datte 'rkayuktā mahadīśatām nrrpaị

sangam padāptim ca brhadgunodayam |

bhaumārkiyuk tadgatadhātujāśubham

datte viśeșān muthahā śaner gṛe \|

3 muthahāyām āpad] muthahāpāpāmāpa G 4 gatāyām] apy add. B N G K T M || svayam] svam BN 15 padāptim] yadāptiñ M 16 yuk tad] yuktañ M 17 datte] dhatte $G$

6-7 bhogyā ... vadet] VT 2.31 14-446.4 datte ... buddhidā] DA 16.5-6 
ger from enemies. By an aspect from a malefic, there is loss of goods and happiness; if [placed] thus [even] in the nativity, destruction of home and wealth.

And Samarasiṃha [says in the Täjikaśāstra]:

If the munthah $\bar{a}$ is in its tail, [there is] misfortune, suffering, and torment from adversaries. If it is thus in the nativity, [too], ${ }^{12}$ [the native's] wealth falls into others' hands, not to be seen by himself.

A definition of the mouth and so on of Rāhu [is found] in Varșatantra [2.31]:13

The degrees yet to be traversed by Rāhu are its mouth; its back are the degrees past. The seventh sign from it is its tail. Considering thus one should predict the results.

'Past' [means] traversed. And Vāmana [says]:

The face of Rāhu are the degrees to be traversed; those traversed are its back; and the seventh [sign from it] is its tail.

Concerning this, Yādava says that a planet which occupies the same sign in the year as it did in the nativity gives the result of its conjunction or aspect with the munthahā in full. Tejahsiṃha, too, describes the results of the conjunctions of the munthahā with the planets [in Daivajñälamkrti 16.5-6, 8]:

Joined to the sun, the munthaha gives great power, the company of princes, attainment of rank, and the dawning of lofty virtues; [but] joined to Mars [or] Saturn, it gives evils arising from the elements residing in them, particularly [when the munthaha $\bar{a}$ is placed] in the domi-

12 'Too' (api), though present in the stanza as attested by all text witnesses, violates the metre and is almost certainly an interpolation, whether originating with Balabhadra or with some subsequent copyist.

13 In Sanskrit texts of this late period, the name Rāhu and its various synonyms normally denote only the moon's north or ascending node; but Arabic astrological works, like earlier Sanskrit sources, refer to the lunar nodes as a single mythical being, of which the north node is the head and the south node the tail. Tajika authors further divide the 'head' into a front part or mouth and a hinder part, a division not found in the quotations from earlier authors like Samarasiṃha and Tejạ̣siṃha (also given below) nor, to my knowledge, in Arabic-language works. 
jīvānvitārthātmajadārasaukhyadā

yutendunā rukkșayaraupyakīrtidā |

śukreṇa yuktārthakalatraśarmadā

saumyānvitā syān muthahārthabuddhidā $\|$

kaver guror vā yutidrșțito 'nthihā rāhvāsyagā dharmadhaneśatāvahā |

tatpucchagā cārijatāpaduḥkhadā datte viśeșād aśubhair yutekșitā \|

anyo 'pi viśeșas tenaivoktah |

nīcasthitena vibalena hatena pāpaị

kendre yutāpi ravinā muthahā na bhavyā |

janmany aniștagrhagā vibalābdakāle

pāpārditā tanugatāngavikārakartrī $\|$

atra raviṇā ity upalakṣaṇam | sarvagrahāṇāṃ nīcādigatvaṃ subhaphalanāśakam jñeyam | anyac ca tatraiva |

janmodayāt kiyati varșavilagnato 'pi

sthāne 'nthihāsti nijanāthabalādiyuktā|

tatsthānakotthaphaladā tanute tathārau

māndyam mṛtim ca mṛtigārikrtāpado 'ntye \|

bhaumārkiyug jvalanarugbhayadenthihā syāt

krūrair hatā janakayor bhayakrc caturthe |

yadbhāvagābdajanușor api ninditettham

tannāśadā balayutātra tu tatphalā dhyyā || iti |

athoktānāṃ muthahāphalānāṃ pākaḥ svāmidaśāyāṃ bhavatīty uktaṃ tājikabhūṣaṇe |

5 dṛșțito 'nthihā] dṛștigemẹthihā G; dṛștigenthihā K T M 7 anyo 'pi] anyośpi N 10 janmany anișta] janmașta B N || vibalābda] vibalānībda B N 11 kartrī] kartī B N 12 sarva] sarve G || nīcādigatvaṃ] nīcārigatā ca G 17 kṛtāpado] kṛdāpado B N G || 'ntye] iti add. B N K T M 18 jvalana] jalana N 21 tu] om. B N \|| phalāḍhyā] phalādyā G a.c.; phalāptyai K T M || iti] om. B N 22 daśāyāṃ] dṛśāyāṃ K

5-6 kaver ... yutekṣitā] DA 16.8 8-11 nīca ... kartrī] DA 16.10 14-17 janmodayāt ... 'ntye] DA 16.9 18-21 bhaumārki ... phalāạhyā] DA 16.11 
cile of Saturn. Joined to Jupiter, the munthahā gives happiness from wealth, wife and children; joined to the moon, it destroys illness and gives silver and renown; joined to Venus, it gives joy from wealth and wife; joined to Mercury, it gives wealth and comprehension.

By the conjunction or aspect of Venus or Jupiter, the inthiha placed in the mouth of Rāhu brings merit, wealth and power; [but] placed in its tail, it gives torment and suffering caused by enemies, particularly if joined to or aspected by malefics.

He himself states another special rule [in Daivajñālaṃkrti 16.10]:

The munthaha joined to the sun occupying its fall, weak [or] afflicted by malefics is not auspicious, even in an angle. Occupying an evil house in the nativity and weak at the time of [the revolution of] the year, afflicted by malefics and occupying the ascendant, it causes illness in the body.

Here, 'the sun' is used elliptically: occupying its fall and so on should be understood to destroy the good results of all planets. And in the same place, [Daivajñälaṃkrti 16.9, 11, he states] something else:

In whatever place the inthih $\bar{a}$ appears, counted from the ascendant of the nativity or the ascendant of the year, endowed with the strength of its own ruler and so on, it gives the results arising from that house. Thus, in the sixth house it produces illness; in the eighth house, death; and in the twelfth house, misfortunes caused by enemies.

Joined to Mars [or] Saturn, the inthihā will give danger from fire and illness, [respectively]; afflicted by malefics in the fourth [house], it makes danger for the parents. Corrupted in this way, it destroys whatever house it occupies [counted] from [the ascendant of] the year or [of] the nativity; but if endowed with strength here, it abounds in the [good] results of that [house].

Next, it is said in Täjikabhūṣaṇa [2.24] that the maturation of the results stated [above] for the munthahā occurs in the period of its ruler: 
yan mūthahāyāḥ phalam uktam atra śubham vimiśram tv aśubhaṃ viśeșāt | tat kalpañ̄yam muthaheśapāke balānumānān nanu buddhimadbhị̣ \|

viśeșam āha yādavasūrị̣ |

janurvilagne sati sāyanāṃse

yatrenthihā tatpatir abdapo 'smin |

śubhe śubham krūrakhage na bhavyam

phalam vaded romakasammatam tat || iti |

iti muthahāvicāraḥ ||

athājñātajanmanaḥ praśnapattrīkaraṇam uktaṃ tājikabhūṣaṇe |

jananasamayalagnājñānabhāve sudhïbhir

vidhivad amalaprcchākālalagnam prasādhyam |

śubhaphalam aśubhaṃ vā kìrtayet sarvam asmān

nigaditavad udārāc chāstrabuddher vicārāt $\|$

tatkālahorākhacarānusāram varșe vicāram vidadhīta dhìmān |

praśnārkatulyo 'grimavarșabhānur yadā tadābdasya bhavet praveśah \||

prcchāvilagnasya vihāya rāśịn vibhājayed aṃśakalākalāpam |

khabānacandrair iha rāśipūrvaphalam vilagnān muthahāsthitị̣ syāt ||

caturthabhāvādhipatir vicintyah svajanmalagnädhipatir balārtham |

2 tat] ta G 6 śubhe] śubho K T M 7 vaded] vade B N 10 lagnājñāna] lagnajñāna KM 11 kāla] pāla N; vāla G 13 vad] tad G K T 14 khacarā-] kharā- N $\quad 16-18$ pṛcchā ... balārtham] om. B N G 18 -patir1] -patim M \| vicintyah]] scripsi; vicintya K T M || patir²] scripsi; patim K T M

1-2 yan ... buddhimadbhị] TBh $2.24 \quad 4-7$ janur ... tat] TYS $8.29 \quad$ 10-13 janana ... vicārāt] TBh $12.6 \quad 14-15$ tat ... praveśạ] TBh $12.9 \quad$ 16-18 pṛcchā ... balārtham] TBh 12.7-8

18 vicintyah ... patir] The emendation is supported by MS TBh2 and TBh Mumbai 2005.

14 The particular association of tropical values with Romaka ('the Roman', see the Introduction) is significant, implicitly confirming the use of sidereal values by other authors. The simple procedure for identifying the ruler of the year stated here is the one found 
The results of the munthaha that have been stated here according to the distinction [between] good, mixed, and evil, should be expected by the wise in the period of the ruler of the munthah $\bar{a}$, in accordance with its strength.

Yādavasūri states [another] special rule [in Tājikayogasudhānidhi 8.29]:

When precession has been added to the ascendant of the nativity, the ruler [of the sign] where the inthih $\bar{a}$ [falls] is the ruler of the year. If it is a benefic, one should declare the result to be good; if a malefic planet, it is not auspicious. That [method] is approved by Romaka. ${ }^{14}$

This concludes the consideration of the munthahā.

\subsection{Finding the Munthaha from a Query}

Next, casting the figure of a query for someone whose [time of] birth is unknown is described in Tājikabhūṣaṇa [12.6, 9, 7-8]:

In case of the ascendant at the time of the nativity being unknown, the wise should establish the ascendant in the prescribed manner for the time of [the client asking] a faultless question. From this one should declare everything, good results or evil, as [they have been] stated, by honest judgement from one's understanding of the science.

The wise man should judge [the results] in [that] year according to the planets at that hour. The revolution of the year will be when the sun in the following year [reaches a longitude] equal to [that of] the sun at the [time of] query.

Excluding the sign of the ascendant at the query, one should divide the totality of its degrees and minutes by one hundred and fifty. ${ }^{15}$ The result in signs and so on is the position of the munthaha from the ascendant. For the purpose of strength [calculations], the ruler of the fourth house should be considered as the ruler of the ascendant in the nativity.

e.g. in the works of Māshāallāh and Abū Macshar, and of later authors dependent on them; see the Introduction.

15 This is the number of minutes of arc in one twelfth-part of a zodiacal sign (dvādaśa m̧śa, $\delta \omega \delta \varepsilon x \alpha \tau \eta \mu o ́ p l o v)$. 
praśnapattre munthānayanam uktaṃ phalapradīpe |

tyaktvā bhaṃ praśnalagnasya kalikāh khākṣabhūhṛtāh |

labdhā rāśyādikā munthā praśnapattre bhavet sphuțā $\|$

iti praśnapattrīkaraṇam \|

atha varșeśavicārah | uktaṃ ca yogasudhānidhau |

vividhabhāvavibhūṣaṇavigrahā sunayanānayanāñcitamanmathā |

yuvativan na vibhāti patim vinā śarad atạ śaradahpatir ucyate \|

atha pañcādhikāriṣu trairāśikeśasattvād ādau trairāśikeśvarā ucyante | uktaṃ ca tājikabhūṣaṇe |

varșasvāmivicārārtham meșāt trairāśikeśvarāḥ|

divārātrikrameṇādau cintanīyā manișibhiḥ \|

tatra trairāśikaśabdena kim ucyata iti ced atrocyate | meșādidvādaśarāśīnāṃ madhye meșādicatușțayam prathamo rāśị | siṃhādicatușțayaṃ dvitīyo rāśị | dhanurādicatușțayaṃ tṛtīyo rāśị | evaṃ niṣpannās trayo rāśayas trairāśikaśabdavācyāḥ | trairāśikasvāmina āha tejaḥsiṃhaḥ |

bhāsvatsitārkibhrgujāh syur ajāc caturṇām

dyusvāmino guruśaśijñakujā niśeśāḥ|

1 munthānayanam uktaṃ phala-] muṃthānayanaphalam uktaṃ B N 2 tyaktvā bhaṃ] tyaktā bham B N T; tatkāmaṃ M 7 śaradaḥ] śaradāṃ B N; śaradām K T M 8 trairāśikeśvarā] trairātrikeśvarā G; trairāśikeśvara K M \| ucyante] ucyate K M 14 dhanurādi] dhanurāśi N; dhanurādirāśi G 16 bhṛgujāḥ syur ajāc] bhṛgujāc K

6-7 vividha ... ucyate] TYS 7.1 10-11 varșa ... manīṣibhih] TBh $1.13 \quad 16-45^{2.2}$ bhāsvat ... ca] DA 5.1

16 A punning verse based on the use of the feminine śarad for 'year' and on pati, also meaning 'husband', for 'ruler'. Bhāva 'emotion' further has the technical meaning '[horoscopic] house'. 
The calculation of the munthaha in the figure of a query is described in the Phalapradīpa:

Omitting the sign of the ascendant at the query, its minutes of arc divided by one hundred and fifty gives the true munthaha in the figure of the query.

This concludes the casting of a figure for a query.

Next, the consideration of the ruler of the year; and it is said in [Täjika ]yogasudhānidhi [7.1]:

Like a young woman, her figure enhanced by a variety of emotions and paying homage to the god of love by the allurement of her beautiful eyes, the year does not shine without its ruler; therefore, the ruler of the year is [now] described. ${ }^{16}$

Next, because the ruler of the triplicity is among the five candidates [for the office of ruler of the year], the rulers of the triplicity are explained first. And it is said in Tājikabhüșaṇa [1.13]:

For the sake of determining the ruler of the year, the wise should first consider the rulers of the triplicities from Aries in order of day or night.

If it should be asked what, then, is meant by the word 'triplicity', [in reply] it is said: among the twelve signs beginning with Aries, the first group is the four beginning with Aries; the second group is the four beginning with Leo; [and] the third group is the four beginning with Sagittarius. ${ }^{17}$ The three groups thus produced are denoted by the word 'triplicity'. The rulers of the triplicities are stated by Tejaḥsiṃha [in Daivajñālaṃkrti 5.1]:

The sun, Venus, Saturn and Venus are the day rulers of the four [signs] from Aries; Jupiter, the moon, Mercury and Mars are the night rulers;

17 Balabhadra's explanation, representing a misunderstanding of the Perso-Arabic source texts, rests on the double meaning of the Sanskrit word rāśi - 'zodiacal sign' or 'group' used in the neologism trirāśi or trairāśika 'triplicity'. See Gansten 2018. 
siṃāt tu te vinimayāt kramataḥ sadeśāḥ

śanyāramantriśaśino dhanurāditaś ca \|

vinimayāt dinarātrivyatyayāt | sadeśāḥ divā rātrau ceśāḥ | maṇittho 'pi |

ravibhrguśaniśukrejyendusaumyāvaneyāḥ

śanikujagurucandrāh svāmino 'hni trirāśau |

guruśaśibudhabhaumādityadaityejyasaurāḥ

sitaśanikujadevejyendavo rātrilagne || iti |

atha divā rātrau trairāśipāḥ

\begin{tabular}{|c|c|c|}
\hline rāśị̣ & divā & rātrau \\
\hline 1 & sūryah & bṛhaspatih \\
\hline 2 & śukraḥ & candrah \\
\hline 3 & śaniḥ & budhah \\
\hline 4 & śukrah & mangalah \\
\hline 5 & bṛhaspatiḥ & sūryaḥ \\
\hline 6 & candrah & śukrah \\
\hline 7 & budhah & śaniḥ \\
\hline 8 & mangalah & śukrah \\
\hline 9 & śaniḥ & śaniḥ \\
\hline 10 & maṇgalah & mangalah \\
\hline 11 & bṛhaspatiḥ & bṛhaspatih \\
\hline 12 & candrah & candrah \\
\hline
\end{tabular}

samarasiṃhena ete trairāśikeśvarā yavanamatenoktāḥ | svamatenānye proktāḥ | tad yathā $\mid$

1 sadeśāḥ] śadeśāh B N 3 rātrau ceśāḥ] rātri îsāạ B N $\quad$ 3-4 maṇittho ... -āvaneyāḥ] om. B N 4 saumyāvaneyāḥ] saumyāvanīsāh G 5 trirāśau] rātrau ca ravisitaśaniśukrā jīva-

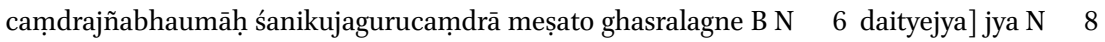
atha ... trairāśipāḥ] trairāśikeśāḥ G; om. K T M 9 rāśi] om. B; rāśayah K T M \| divā] dine G; dineśā K T; dineśāḥ M $\|$ rātrau] rātreśā K T; rātrīśāḥ M 12 budhah] bṛ M 14 sūryaḥ] bu M 20 bṛhaspatiḥ̣] gu B G || bṛhaspatị̣²] gu B G 22 -siṃhena] -siṃhe B N; -siṃhenā G \| ete] etau B N \| trai-] om. B N

8 atha] The following table is omitted by $\mathrm{N}$. The remaining text witnesses abbreviate the names of the planets. 
[of the four signs] from Leo, they are reversed in order; the constant rulers [of the four signs] beginning with Sagittarius are Saturn, Mars, Jupiter and the moon.

'Reverse' [means] by reversal of day and night. 'Constant rulers' [means] rulers by both day and night. And Manittha [says]:18

The sun, Venus, Saturn, Venus, Jupiter, the moon, Mercury, Mars, Saturn, Mars, Jupiter and the moon are the [respective] triplicity rulers [of the twelve signs] by day; Jupiter, the moon, Mercury, Mars, the sun, Venus, Saturn, Venus, Saturn, Mars, Jupiter and the moon [are the rulers] in a night horoscope.

These are the triplicity rulers by day and night:

\begin{tabular}{lll}
\hline Sign & By day & By night \\
\hline Aries & Sun & Jupiter \\
Taurus & Venus & Moon \\
Gemini & Saturn & Mercury \\
Cancer & Venus & Mars \\
Leo & Jupiter & Sun \\
Virgo & Moon & Venus \\
Libra & Mercury & Saturn \\
Scorpio & Mars & Venus \\
Sagittarius & Saturn & Saturn \\
Capricorn & Mars & Mars \\
Aquarius & Jupiter & Jupiter \\
Pisces & Moon & Moon \\
\hline
\end{tabular}

Samarasiṃha says [in the Täjikaśāstra] that these triplicity rulers are according to Yavana opinion. According to his own opinion they are different, as follows:

18 This stanza is not attested in available independent witnesses of the Varșaphala. 
meșādicatustrairāśikeśvarā ravisitārkibhrgavo 'hni|

guruśaśibudhabhaumā niśi śanikujagurvindavah satatam ||

divase dinapasadeśau rātrau rātripasadeśau ca|

anayor yo balayukto jñeyas trairāsināyakah khețah \|

tājikamuktāvalyām api |

ravibhrguśaniśukrās trị̆ parāvartanena

kriyata iha diveśâh syuḥ sadeśáś ca tadvat |

śanikujagurucandrā rātrināthās tathaivā-

maraguruśaśisaumyakșmāsutāś ca krameṇa || iti |

\begin{tabular}{|c|c|c|c|}
\hline rāśị̣ & dine & rātrau & sadeśvarāḥ \\
\hline 1 & sūryah & brhaspatih & śaniḥ \\
\hline 2 & śukrah & candrah & mangalah \\
\hline 3 & śaniḥ & budhah & bṛhaspatiḥ \\
\hline 4 & śukrah & maṇgalah & candrah \\
\hline 5 & sūryaḥ & bṛhaspatih & śanih \\
\hline 6 & śukrah & candrah & maṇgalah \\
\hline 7 & śaniḥ & budhah & bṛhaspatiḥ \\
\hline 8 & śukrah & maṇgalah & candrah \\
\hline 9 & sūryaḥ & bṛhaspatih & śanih \\
\hline 10 & śukrah & candrah & mangalah \\
\hline 11 & śaniḥ & budhah & bṛhaspatiḥ \\
\hline 12 & śukrah & maṇgalah & candrah \\
\hline
\end{tabular}

1 trairāśikeśvarā] scripsi; trirāśikeśvarā B N G K T M $\|$ bhṛgavo] bhṛgujo B N 2 gurvindavah] gurvendavah K T 3 dinapasadeśau] dinasaddeśau B N; dinapasaddeśau K T; dinapasadṛ́sau M \| sadeśau²] saddeśau K T; sadṛ́au M 4 bala] bāla M || nāyakah] nākah B N 6 parāvartanena] parārtanena K T 8 kujaguru] gurukuja K T M 9 kṣmā] om. T \| iti] om. G 10 rāśi] rāśișu K T M \| dine] trairāśikeśâh add. G; rāśive K T M \| rātrau] rātrīśvarā G M; rātreśvarā K T || sadeśvarāḥ] śadreśvarā K; śadreśva T M 11 sūryaḥ] ra B \| bṛhaspatị̣] gu G 13 bṛhaspatih] gu G 14 mañgalah] śa K T M 15 bṛhaspatih] gu G 16 candrah] bu K T M 17 bṛhaspatih] gu G; bu T 18 manggalah] bṛ K T M $\quad 19$ bṛhaspatih] gu G 21 bṛhaspatih] gu G 22 candrah] bṛ T

1-2 meșādi ... satatam] Cf. KP $1.21 \quad 6-9$ ravi ... krameṇa] TMṬ 1.12

1 trairāśikeśvarā] The emendation, required by the metre, is supported by Mss $\mathrm{KP}_{1}, \mathrm{KP}_{2}, \mathrm{KP}_{4}$ and KP Mumbai 1884. 10 rāśị] The following table is omitted by N. The remaining text witnesses abbreviate the names of the planets. 
The triplicity rulers of the four [signs] beginning with Aries are the sun, Venus, Saturn and Venus by day; Jupiter, the moon, Mercury and Mars by night; and, Saturn, Mars, Jupiter and the moon at all times. By day, the day ruler and the constant ruler [should be taken]; at night, the night ruler and the constant ruler. Of these two, the planet that is endowed with [greater] strength should be known as the triplicity ruler. $^{19}$

And in Tājikamuktāvali[țippaṇī 1.12 it is said]:

Here, repeating thrice from Aries, the sun, Venus, Saturn and Venus are the rulers by day; the constant rulers likewise are Saturn, Mars, Jupiter and the moon; so also, the night rulers are Jupiter, the moon, Mercury and Mars, respectively.

\begin{tabular}{llll}
\hline Sign & By day & By night & Constant ruler \\
\hline Aries & Sun & Jupiter & Saturn \\
Taurus & Venus & Moon & Mars \\
Gemini & Saturn & Mercury & Jupiter \\
Cancer & Venus & Mars & Moon \\
Leo & Sun & Jupiter & Saturn \\
Virgo & Venus & Moon & Mars \\
Libra & Saturn & Mercury & Jupiter \\
Scorpio & Venus & Mars & Moon \\
Sagittarius & Sun & Jupiter & Saturn \\
Capricorn & Venus & Moon & Mars \\
Aquarius & Saturn & Mercury & Jupiter \\
Pisces & Venus & Mars & Moon \\
\hline
\end{tabular}

19 The first of these sentences comprises a stanza in $\bar{a} r y \bar{a}$ metre also found in Samarasiṃha's surviving work Karmaprakāśa (1.21) and already quoted in section 2.5 above. For the varying Tajika doctrines on the triplicities, see the Introduction and Gansten 2018. 
anayos trairāśikeśvarayor viṣayavyavasthoktā tatraiva |

divā dinādhīśasadeśayor yo rātrau tu rātrīśasadeśayoś ca| trairāśikeśo balavān grahaḥ syān naisargikas tulyabale vicintyaḥ || iti |

dinādhīśasadeśayo rātrīśasadeśayor vā madhye yo balavān sa grāhyah | balasāmye tejaḥsiṃhādyuktā nisargās trairāśikeśvarā jñeyā iti ||

atha varșeśārthaṃ pañcādhikāriṇa āha samarasiṃhaḥ |

atha varșaiśvaryakrte pañcānveșyāh purenthihādhišaḥ|

hāyanalagnasvāmì tattrairāsiikapatis tadanu|

dinavarșe ravir indur niśi caiko janmalagnanāthaś ca \|

atra sūryaśabdena sūryākrāntarāśî́varaś candraśabdena candrākrāntarāśī- $\quad 10$ śvara ucyata iti | ata eva tejạ̣siṃhena spașțam uktam |

varșādhipāh syur iha pañca ravīndurāśyor eko 'dhipo 'hni niśi ca kramato 'nthiheśạ̣| sambhūtilagnavibhur abdavilagnapas tattrairāsíipaś ca punar eșu balam vilokyam \|

2 sadeśayor] sadṛśayor K T \| rātrīśa] rātrīrā N $\|$ sadeśayoś] sadṛśayoś K T 3 tulya] tv alpa B N 4 sadeśayo] sadṛ́śayo K T M \| sadeśayor] sadṛ́ayor K T M \| madhye ... grāhyah] om. B N G 10 candraśabdena] om. B N 11 iti] ity arthah G; ity artha T 13 eko 'dhipo] ekādhipo G K T M || kramato 'nthiheśah] kramateṃtthiheśạ̣ G; kramateṃthiheśah K T M 14 vibhur] vir N; vidhur K M \| vilagnapas tat] scripsi; vilagnapaś ca B N G K T M 15 punar eșu] scripsi; puradeva B N; punar eva G K T M

2-3 divā ... vicintyah] TMṬ $1.13 \quad$ 12-15 varṣā ... vilokyam] DA 14.1

14 vilagnapas tat] The emendation, suggested by the source verse from the TŚ, is supported by MS DAı. 15 punar eșu] The emendation is supported by MS DA1. 
The verdict on the matter of [selecting one of] these two triplicity rulers is described there too [1.13]:

The stronger planet of the two - the day ruler and the constant ruler by day, and the night ruler and the constant ruler by night - will be the triplicity ruler. In case [they are] of equal strength, the one [stronger] by nature should be considered [the ruler].

The stronger one of the day ruler and the constant ruler, or of the night ruler and the constant ruler, should be taken. In case of equal strength, the [planets stronger by ${ }^{20}$ nature explained by Tejahsimpha and others should be understood to be the triplicity rulers.

\subsection{Finding the Ruler of the Year}

Next, for the purpose of [determining] the ruler of the year, Samarasimha explains the five candidates [in the Tājikaśāstra]:

Now, for the sake of rulership of the year, five [planets] should be sought: first, the ruler of the inthihä; then the ruler of the ascendant of the year and its triplicity ruler; in a year [commencing] by day the sun is one, [in a year commencing] at night, the moon; and the ruler of the ascendant of the nativity.

Here, the word 'sun' means the ruler of the sign occupied by the sun, and the word 'moon' means the ruler of the sign occupied by the moon. Therefore, Tejạ̣siṃha describes it clearly [in Daivajñălaṃkṛti 14.1]:

The [potential] rulers of the year here are five: one is the ruler of the sign of the sun or the moon by day or night, respectively; [another is] the ruler of the inthih $\bar{a}$; the ruler of the ascendant of the nativity; the ruler of the ascendant of the year; and then its triplicity ruler. The strength of these [five] is to be examined.

20 Although one or more words seem to be missing here, all text witnesses agree on this reading. 
maṇittho 'pi |

divā vilagne ravināyako 'pi rātrau vidhor janmavilagnapaś ca| varșapraveśe tanupo 'nthiheśas trirāśināthaḥ kathito 'dhikāre \|

vāmano'pi |

janmalagnābdalagneśau dyuniśārkendurāśipau|

trirāśināyakentheśau jñātavyās te prayatnatạ̣\|

tājikabhūṣaṇe 'pi |

janmodayābdodayamunthaheśā varșapraveśe divase 'rkabheśạ̣| niśindubheśas triĝ̣heśa ete varșādhipatye hy adhikāriṇaḥ syuḥ \|

muktāvalyām api |

muntheśo varșalagneśas tattrairāśikanāyakaḥ

divārkarāśināthaś ca rātrau candrarkṣanāyakaḥ\|

janmalagneśvaraś caivaṃ varșe pañcādhikāriṇaḥ|

eteșu balavāl lagnam paśyed yaḥ so 'bdanāyakaḥ|

anīsṣamāṇo lagnam ca sabalo 'py abdapo na hi $\|$

yādavo 'pi |

janmalagnapatir inthihādhipo 'harniśam raviśaśān்arāśipaḥ| syus trirāśipatir abdalagnapạ̣ pañca hāyanapatitvayogyakāḥ \| lagnaṃ prapaśyann adhivirya eșām varșeśvaraḥ syād atha drștyabhāve | vīryādhiko nābdavibhur vivīryo lagnam prapaśyann api hāyaneśah |

3 'nthiheśas] mutheśas K T M 5 janma] janmaga G 6 prayatnatah $]$ pramalatah $\mathrm{N} \quad 7$ 'pi] om. B N 8 varșa] varșe $\mathrm{G} \|$ praveśe] praveśo B N K T M 9 trig̣̣heśa] tripadeśa B || ete] rāte G || varșādhipatye] varșā5dhepatye N; varșādhipā ye G 11 tattrairāśika] trairāśyarāśi B N $\quad$ 13-14 janma ... nāyakaḥ] om. B N 15 anīkṣamāṇo] anīkṣyamāṇaṃ B; anīkșamāṇaṃ N 17 lagna] lagne G $\|$ patir] patim B N 18 patitva] yatitva M 19 prapaśyann] prapaśyenn $\mathrm{K} T$; prapaśyed $\mathrm{T} \quad 20$ vivīryo] vivīrya B N $\|$ prapaśyann] prapaśyenn K T; prapaśyed M

2-3 divā ... 'dhikāre] VPh 7-8; cf. HS 31-32 8-9 janmodayā ... syuh] TBh $1.34 \quad 11-14$ muntheśo ... nāyakah] TMṬ 4.3-4 17-46o.1 janma ... vidheyah] TYS 7.3-4 
And Manittha [says in Varșaphala 7-8]:

If the horoscope [of the revolution] is by day, the ruler of the sun; if by night, that of the moon; the ruler of the ascendant of the nativity; the ruler of the ascendant at the revolution of the year; the ruler of the inthih $\bar{a}$; and the triplicity ruler: [these are] declared to have authority [in the year].

And Vāmana [says]:

The rulers of the ascendant of the nativity and the ascendant of the year; the rulers of the sun [or] moon [by] day [or] night; the triplicity ruler and the ruler of the inthihä: these should be carefully investigated.

And in Tājikabhūṣaṇa [1.34 it is said]:

The rulers of the ascendant of the nativity, the ascendant of the year, and the munthahä; the ruler of the sign of the sun if the revolution of the year is by day, the ruler of the sign of the moon [if it is] at night; [and] the triplicity ruler: these are the candidates for rulership of the year.

And in [Tājika]muktāvali [țippaṇ̄ $4 \cdot 3-4$ it is said]:

The ruler of the munthahä; the ruler of the ascendant of the year; the ruler of its triplicity; by day, the ruler of the sign of the sun; at night, the ruler of the sign of the moon; likewise, the ruler of the ascendant of the nativity: [these are] the five candidates [for rulership] of a year. Among them, one that is strong and aspects the ascendant is the ruler of the year; one not aspecting the ascendant, although strong, is not ruler of the year.

And Yādava [says in Tājikayogasudhānidhi 7.3-4]:

The ruler of the ascendant of the nativity; the ruler of the inthihä; the ruler of the sign of the sun and moon by day and night, [respectively]; the triplicity ruler; and the ruler of the ascendant of the year: [these] five are eligible for rulership of the year. Of these, [one] aspecting the ascendant and being of great strength will be ruler of the year. In the absence of [such] an aspect, [even] one great in strength is not ruler 
virrye samāne 'pi tanum prapaśyed drștyādhiko varșapatir vidheyaḥ \|

tājikakaustubhe 'pi |

eșām yah khacaras tanuṃ bahudriśā paśyet sa varșādhipo

dṛksāmye 'dhibalaś ca tejasi same naikādhikārì nrrpaḥ|

tatsāmye muthahāpatị̣ sa yadi no paśyet tadāhny arkapo

rātrau candrabhapo 'tra no yadi vibhuh proktas tribheśas tadā $\|$

na paśyet sa candro na candretthaśálah

sa cen naiva paśyet tadā lagnapạ̣ syāt |

na paśyec ca lagnam tadā no sameśạ

sameśam vinā mrtyur eva pradiștah || iti |

vāmano'pi |

dṛ̦tyabhāve tu samgrāhyas tasmād alpabalo grahah |

samasaṃkhyābale jāte tadā drștyādhikah patị̣ \|

yādavah |

dṛsțau samāyām bahavo 'dhikārā yasyeșuvargyā śaradīśvaraḥ saḥ|

samarasiṃho 'pi |

2-10 tājikakaustubhe ... iti] om. B N G 5 tadāhny] scripsi; tadā hy K T M 6 vibhuḥ] scripsi; vidhuh K T M 12 dṛsțyabhāve] dṛșțābhāve B; dṛsṭyābhāve N G K T 13 dṛsțyādhikaḥ] dṛsțtyādhipah B 15 vargyā] vargyāṃ M 16 samarasiṃho] sarasiṃho N

15 dṛșțau ... sah] TYS 7.4 
of the year; but even [a planet] without strength, aspecting the ascendant, is ruler of the year. If the strength [of several planets] is equal, [if one] aspects the ascendant [being] greater by aspect [strength], it should be made ruler of the year.

And in the Täjikakaustubha [it is said]:

Among these, the planet that aspects the ascendant with a great aspect is ruler of the year; if the aspects are equal, the one of greater strength [is ruler of the year]; if the power is equal, the one with more claims is ruler; ${ }^{21}$ if those are equal, the ruler of the munthah $\bar{a}$ [is ruler of the year]; if that one does not aspect [the ascendant], then the ruler of the sun by day, the ruler of the sign of the moon by night; if these [do] not [aspect the ascendant], then the triplicity ruler is declared ruler [of the year. If] that [planet] does not aspect [the ascendant], the moon [is ruler of the year; if] not, [then the planet] that has itthaśāla with the moon; if that does not aspect [the ascendant] either, then the ruler of the ascendant will be [ruler of the year]. And if [that planet] does not aspect the ascendant, then there is no ruler of the year. Without a ruler of the year, death is predicted.

And Vāmana [says]:

In the absence of an aspect [from a strong planet], a planet of lesser strength than it should be taken; if the strength [of two or more planets] amount to the same, then the one greater by aspect is ruler [of the year].

[And] Yādava [says in Tājikayogasudhānidhi 7.4]:

When the aspect is equal, the one that has more claims among the five dignities is ruler of the year.

And Samarasiṃha [says in the Tãjikaśāstra]:

21 That is, a single planet holding several of the relevant rulerships (over the munthaha, the ascendant of the annual revolution, and so forth). 
varșapatitve drsțte pracurānām pañcavargikāmadhye | yasya bahavo 'dhikārās tasyaiśvaryam hi parikalpyam \|

atra dṛștisamatve janmalagnapavarṣalagnapetyādyuktādhikārapañcakamadhye yasya bahavo 'dhikārāḥ sa eva varṣādhipa ity uktam | tājikasāre |

yadābdalagnam bahavo nabhogāḥ paśyanti cet pañcadivaukasāṃ hi | madhye 'dhikārā bahavo 'pi yasya tasyābdapatvam gaditạ̣ pravinnaịn \|

yādavaḥ |

dṛsțeh samatve 'py adhikāratulye divā nišinendugṛāadhināthah | drșțir na tasya tribhapo na tasya drșțis tadā candramasetthaśálah $\|$ kenāpi so 'bdādhipatir vinetthaśálaṃ tadā yas tanupaḥ pradiștah |

tājikatilake 'py evam evoktam |

paśyen na lagnaṃ yadi pañcamadhye ko vā tadā bahvadhikāranāthạ \| evam na cet syād bahuvīryakhețo hy asyāpy abhāve 'bdavilagnapena | syān mūthaśīlaṃ śaradīśvaro 'syābhāve bhaven munthahanātha iśah || iti |

atra pañcādhikāriṇāṃ dṛsṭ̂yabhāve varṣalagneśo 'bdapa ity uktaṃ muktā- 15 valyām |

1 dṛștẹ] dṛsțeh B N || vargikā] vargikāṇāṃ K T M $\quad 2$ parikalpyam] parikalpam K T M 3 lagnapa] lagnepa $\mathrm{N} \quad 4$ sa] om. B N 5 cet pañca] cetthaṃ ca M 6 'dhikārā] dhikāro T 6-9 tasyābda ... tasya] om. K T M 7 yādavaḥ] yādavaiḥ N 8 dṛștẹe ] dṛ̣țe B N G || gṛhā-] grahā- $\mathrm{G} 9$ dṛștis] dṛștes $\mathrm{N} \quad 10$ so] śo $\mathrm{B} \mathrm{N} \quad 10-12$ yas ... tadā] om. B N 13 na] om. B N || khețo] khețe B N || hy asyāpy] svasyāpy B N 15 atra] atha K T M || dṛsțyabhāve] dṛsțyābhāve B N

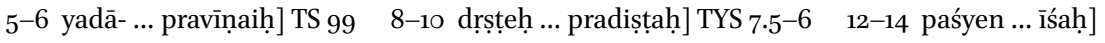
TYS $7.6-7$ 
When several [planets] are seen to have [qualifications for] rulership of the year, the rulership should be assigned to the one with more claims from among the five dignities.

This is [what is being] said here: when the aspects are equal, only that [planet] which has more claims from among the five dignities [previously] described - the ruler of the ascendant of the nativity, the ruler of the ascendant of the year, and so on - is ruler of the year. [And] in Tajjikasāra [99 it is said]:

When many planets aspect the ascendant of the year, experts declare that the rulership of the year belongs to that one among the five planets that has more claims. ${ }^{22}$

[And] Yādava [says in Tājikayogasudhānidhi 7.5-6]:

When the aspect is the same and the claims are equal, the domicile ruler of the sun or moon by day or night, [respectively; if] that one has no aspect, the triplicity ruler; if that one has no aspect, then whichever [planet] has an itthaśäla with the moon is ruler of the year. Without an itthaśála, the one that is ruler of the ascendant is declared [to rule the year].

The same thing, too, is said in the Tãjikatilaka. [Continuing from Tãjikayogasudhānidhi $7.6-7$ :]

If none among the five aspects the ascendant, then the ruler of more claims; if it cannot be thus, [then] the planet with more strength; in the absence even of that, [the planet that has] a mutthasila with the ruler of the ascendant of the year will be ruler of the year; in the absence of that, the ruler of the munthaha will be ruler [of the year].

Regarding this, it is said in [Täjika]muktāvali[țippaṇi 4.9] that, in the absence of any aspect [to the ascendant of the year] from the five candidates, the ruler of the ascendant of the year is ruler of the year:

22 Strictly speaking, if at least one planet has more than one claim to authority, the number of planets vying for rulership is necessarily less than five. 
pañcādhikāriṇo lagnaṃ na paśyanti yadā tadā | varșalagneśvaro yas tu sa evābdapatir bhavet ||

evaṃvidhe viṣaye prakārāntaram uktam tājikabhūṣaṇe |

paśyen na kaścid yadi varșalagnaṃ tallagnarāśir janane 'piyena | dṛșto 'dhipaḥ syān na ca tatra drșțas tadenthiheśo 'pi vicintanīyaḥ || iti |

atra pañcādhikāriṇāṃ dṛ̦țtyabhāve yādavasūrimatena pariṇāme muthaheśo varșapah | tukajyotirvinmatena varṣalagneśah | gạ̣eśadaivajñamatena pañcādhikārimadhye janmani varṣalagnanirīkșakah | tatra viṣayavyavasthā | trayāṇām eșāṃ madhye yaḥ sthānādiṣaḍbalenādhikabalaḥ sa eva varṣeśah | nanu pūrvam yādavena bahuviryakhețah uktah | sa eva punar balavaśenaiva kathaṃ varșeśvaratvam | ucyate | yādavena bahuviryakhețah uktah | tatra bahuvīryakhețah sāmānyapañcavargyāṃ daśādhikabalaḥ viśeșabale pañcarūpādhikabalo bhavati | na tu tannyūnabalaḥ | atra tu trayānāạn madhye yasyaiva kiṃcid balādhikyaṃ tasyaiva varṣeśvaratvam iti sarvạ̣ sustham | yadaite trayo 'pi samabalās tadā yādavagaṇeśadaivajñatājikatilakoktyā muthaheśa eva varșeśa iti tattvam \|

6 dṛsțyabhāve] dṛstyābhāve B N G || matena] om. B N 7 tuka] tattuka K T M $\|$ jyotirvin] jyotir B N 8 pañcādhikāri] pañcādhikāra B N || lagna] om. B N $\quad 9$-ādhikabalaḥ] -ādhikābalaḥ N 10 yādavena] yādavema G \| uktaḥ] uktas K T M 10-11 sa ... uktaḥ] om. G K T M 12 bahu] om. G $\|$ bale] balo K T; balah M 13 balo] bale K T $\|$ tannyūna] tamnnyūna B N; tryūna G $\|$ atra tu] atru N $\|$ madhye] yasyai add. T 14 sarvaṃ sustham] sarvam utpannam $\mathrm{G}$

1-2 pañcā- ... bhavet] TMṬ 4.9 4-5 paśyen ... vicintanīyah] TBh 1.37 10 bahu ... khețaḥ] TYS $7.7 \quad 11$ bahu ... khețah] TYS 7.7

3 prakārāntaram] The unexpected neuter form is attested by all witnesses. 
When the five candidates do not aspect the ascendant, then the one that is ruler of the ascendant of the year itself becomes ruler of the year.

Another approach to this kind of topic is stated in Täjikabhüșaṇa [1.37]:

If no [planet] should aspect the ascendant of the year, the one that aspected the sign of that ascendant in the nativity will be ruler [of the year]; [if that sign] was not aspected even then, the ruler of the inthih $\bar{a}$ should be considered [ruler of the year].

Here, in the absence of aspects [to the ascendant of the year] from the five candidates, the final ruler of the year, in the opinion of Yãdavasūri, is the

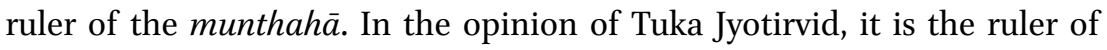
the ascendant of the year. In the opinion of Ganeśa Daivajña, it is that one among the five candidates which aspected [the sign of] the ascendant of the year in the nativity. The verdict on this matter [is this]: of these three, the strongest one in the sixfold strength of place and so on is indeed ruler of the year. [If you] object: 'The planet with more strength' was already mentioned by Yãdava. How can it again [be eligible for ${ }^{23}$ ruling the year simply on account of its strength? - [then in reply] it is said: 'The planet with more strength' was mentioned by Yàdava. In that context, a planet with more strength in the general five dignities is one with more than ten [units of] strength; in the detailed [scheme of] strength, one with more than five [units of] strength; but not one with less strength than that. But here, out of the three [planets suggested above], the rulership of the year belongs to the one that has just a little more strength [than the others]. Thus all is well [resolved]. And if these three are equal in strength, then by the statements of Yādava, Gaṇeśa Daivajña, and the Täjikatilaka, the ruler of the munthahā itself is ruler of the year. This is the truth of the matter.

23 A verb appears to be missing in the two earliest text witnesses (B N). In the others, this and the following sentence have been omitted altogether. 
athājñātajanmanaḥ praśnapattre varṣeśānayanaṃ tājikasāre |

praśnāngapo varșapatih prakalpyas turyeśvaro janmavilagnanāthaḥ| munthādhipaḥ praśnavilagnataś ca trairāśipo ghasrapatih purāvat || iti |

yadā punar muthaheśo varṣeśo jātas tadā viśeṣaphalam āha samarasiṃhaḥ |

muthaheśo varșapatịh sthāpyo 'sminn astage phalaṃ na śubham |

janmani yasmin rāśau tasmin varṣe sthita h phalaṃ pūrṇam \|

ayam arthah | muthaheśo janmani śubhasthānago varșe 'pi śubhasthānagatas tadā śubhaṃ phalaṃ pūrṇam | ubhayatrānișțasthānagatas tadā aśubhaṃ phalaṃ pūrṇam | yadā janmani śubhasthānago varṣe aśubhasthānagas tadvarșe pūrvārdhe aśubhaṃ phalam varșottarārdhe śubham phalam | viparīte viparītam phalam jñeyam ity arthạ ||

atha candrābdapatve viśeșo muktāvalyām |

candraiśvarye tu yenendur bhavet pūrnetthaśälakrt ||

sa varșeśo bhaven nūnam no cen muthaśilam tadā $\mid$

candrarāsiśśvaro 'bdeśạ sa ced indur bhaved yadā $\|$

tatphalam sūryavad vedyam śreșthamadhyādhamam tadā |

candradhātvanusāreṇa khindakasyeti sammatam || iti |

2 prakalpyas] prakalpyo $\mathrm{G} \quad 4$ varṣeśo] om. G 5 śubham] súbhagam B N 7 varṣe] varṣo N; varge G 8 ubhayatrānișța] ubhayatrāpi nașța $G$ \| sthānagatas] sthānagas G 10 tadvarșe] tadā varṣa G K T M 11 viparīte] om. B; viparī N 14 nūnaṃ] nyūnaṃ B N G K $\quad 16$ madhyādhamaṃ] madhyamaṃ B N || tadā] dā N 17 khindakasyeti] khindhikasyeti K M

2-3 praśnā- ... purāvat] TS $102 \quad 13-17$ candrai- ... sammatam] TMṬ 4.6-8

24 While this reads like a general rule, it may have be preceded by qualifying conditions in the text quoted.

25 Again, a verb appears to be lacking but may be given in a subsequent verse.

26 But Samarasiṃha is not speaking of generic good or evil places, but of a planet returning to the actual zodiacal sign that it occupied in the nativity. The sun will occupy its natal sign in every revolution; Mercury and Venus, quite often; Jupiter and Saturn, at approximately twelve- and thirty-year intervals, respectively; Mars and the moon, less regularly.

27 Although supported by all text witnesses, this interpretation of Balabhadra's contradicts the principle quoted above from the Hilläjatäjika, to the effect that placements 


\subsection{Special Considerations}

Next, the calculation of the ruler of the year in the figure of a query for someone whose [time of] birth is unknown [is explained] in Tājikasāra [102]:

The ruler of the ascendant of the query should be considered ruler of the year; the ruler of the fourth, ruler of the ascendant of the nativity; the ruler of the munthaha [should be known] from the query ascendant; the triplicity ruler [is] the ruler of the day, as before.

Further, when the ruler of the munthaha becomes ruler of the year, Samarasiṃha states a special rule [in the Tãjikaśāstra]:

The ruler of the munthaha should be made ruler of the year. ${ }^{24}$ If it is [heliacally] set, the result is not good. Occupying, in [the revolution of] the year, the sign in which [it was placed] in the nativity, [it gives its] full results. ${ }^{25}$

The meaning is as follows: the ruler of the munthahā occupies a good place in the nativity, and also occupies a good place in [the revolution of] the year. Then the good results are complete. ${ }^{26}$ [If] it occupies an evil place at both [times], then the evil results are complete. When it occupies a good place in the nativity [but] an evil place in the year, in that year results are evil in the former half; in the latter half of the year, results are good. ${ }^{27}$ If the opposite, the results should be understood to be the opposite: this is meant.

Next, a special rule when the moon is ruler of the year [is stated] in [Täjika]muktāvali[țippaṇi 4.6-8]:

When the moon holds the rulership [of the year], that [planet] with which the moon forms a perfected itthaśäla will certainly be ruler of the year. If there is no mutthasila, then the ruler of the moon's sign is ruler of the year. If the moon [itself] should be that [ruler], ${ }^{28}$ then its results should be known in the manner of the sun, [whether] superior, middling or inferior, [but] in accordance with the essence of the moon: this is accepted by Khindika.

in the nativity correspond to the former part of the year, placements in the revolution to the latter half. Possibly the words śubha 'good' and aśubha 'evil' were transposed in this prose section of the text at an early point in the transmission. 
atra candraś cet trairāśikeśvaras tadā candra eva varșeśvaro jñeyas trairāśikeśvaratvābhāve yena candro muthaśilī sa eva varṣapa iti viśeșa uktas tejahsimhena|

drștyādikair api samo 'hni ravir nisīindus

trairāsikotthavibhutābhṛ asau na cet syāt |

syād vā tadā muthaśilì ca khagena yena

sthāpyah patị̣ sa tam ṛte śaśirāśipas tu \|

grahajñābharaṇe 'pi |

trairāśikeśo na bhaved yadīnduś candreśvaratve 'pi khagena yena |

mukhyākhyayogo 'sya sa iśa ukto vinā tam indor grhapo 'bdapah syāt || iti |

mukhyayoga itthaśālākhyaḥ | atra viśeșāntaram āha vaidyanāthaḥ |

varșe candretthaśālāt tu yo 'bdapas tasya janmani |

kambülam indunā janmarātrau varșaṃ tadottamam || iti |

atra pañcādhikārināạ madhye pañcavargyā balayuto 'pi lagnadarśì durūḥphoktanirbalagrahalakșaṇayuto varșeśo na bhavatīty api viśeșo dhyeyah |

4 samo] same B N G T 6 khagena] ragena M \| yena] om. K T 9 na bhaved] bhanabhaved B a.c.; bhanaved B p.c. 10 mukhyākhyayogo 'sya] mukhyayogptesya N \| sa iśa ukto] sadeśayukto B N || vinā tam] vinītam B; vinīnītam N || indor] indu B N G || gṛhapo] grahapo B N 11 yoga] scripsi; yogo B N G K T M 13 varșaṃ] varṣe K T 14-15 atra ... dhyeyah] om. B N 14 darśī] scripsi; daśī G; dṛśa K T M

4-7 dṛsțy ... tu] DA 14.3 
On this matter, Tejaḥsiṃha states a special rule [in Daivajñālaṃkrti 14.3]: if the moon is the triplicity ruler, ${ }^{29}$ then the moon itself should be understood to be ruler of the year; [but] if it is not the triplicity ruler, only that [planet] with which the moon is in mutthaśila is ruler of the year:

If the sun by day [or] the moon by night, though equal [to other planets] with regard to aspects and so on, does not carry the authority arising from triplicity, and if it then forms a mutthaśila with any planet, that [planet] should be made ruler [of the year]; but without such [a planet], the ruler of the moon's sign [is ruler of the year].

And in the Grahajñābharana [it is said]:

If the moon does not become triplicity ruler when the moon holds the rulership [of the year], the planet with which it has the configuration called 'principal' is said to be ruler [of the year]. Without that, the ruler of the moon's sign will be ruler of the year.

The principal configuration is the one called itthaśāla. On this matter, Vaidyanātha states another special rule:

[If] that [planet] which is ruler of the year by virtue of an itthaśa la with the moon in the year has a kambüla with the moon in the nativity, in a night birth, ${ }^{30}$ then the year is excellent.

Concerning this, another special rule is to be considered: among the five candidates, one which, although endowed with the strength of the five dignities and aspecting the ascendant, possesses the characteristics of a weak planet called duruhpha, does not become ruler of the year. ${ }^{31}$

29 Presumably of the ascendant in the revolution of the year, as discussed at the beginning of section 5.8 .

30 Literally, 'in a birth night' (janmarātrau); but this seems the most likely intended meaning.

31 For duruhpha, see section 3.16. 
atha varșeśasāmānyaphalam āha samarasiṃhaḥ |

sa yadi śubhayuktadrșțah șașțhāșțāntyagrhavarjito 'bhyuditaḥ| sarvādhikārayukto janmani varșe ca sadrśabalah \| tad aśeșam uttamam syāt svāmitvam vapuṣi balam atīva sukham | mahatah sthānasyāptis tad anu ca janmagrahānusārāc ca \|

ayam arthaḥ | varșeśo janmani satsthānagatạ śubhadṛștaś ced bhavati tadā śubham varṣaphalam avikalaṃ syāt | dușțasthānādigatah pāpadṛștaś ced bhavati tadā dușțaphalam avikalaṃ vācyam | miśratve miśraṃ phalam | tājikasāre |

kendratrikoṇāyagate 'bdanāthe saumye ca ramyah sakalas tadābdaḥ| șadaștarihphopagate vivirye kaștaprado 'sau gadito munindraih || munthābdabhugrandhrasamānganāthā nāstaṃgatā virryayutās tam abdam | ramyaṃ sukhārthāgamanaṃ vilāsam kurvanti te vyatyayato vilomam \| atha samādhipatau trișaḍayage khalakhage sakalam sabale śubham | vyayavināśagate 'bdapatau tad̄a na ca śubham gaditam munibhir nụnām || iti |

atha viśeșam āha tejaḥsiṃhạ̣ |

maitre saumye sve ca varge sthito 'tha tyaktāștāntyadvid jayi cottarasthah | mitraị saumyair drștayukto 'rkamukto datte 'bdeśah sarvaśarmākhilābdam ||

1 atha] atra B N KM $\quad 2$ sa yadi] sapadi M $\|$ yukta] scripsi; yuta B N G K T M 3 janmani] janma B N $\quad 5$-āptis] -āptiṃ K T M $\quad 8$ avikalaṃ] aviphalaṃ N $\quad 14$ sukhā] sukhyā K $\quad 15$ vyatyayato] vyastam ato K T M 17 khala] khala add. N 19 śubham ] subhaṃ G 21 sve] khe G 22 tyaktā-] tyaktvā- M || jayī] jayo M \| cottarasthậ] cottarasya B N 23 yukto] yuto B N || 'rkamukto] vamukto B N

10-19 kendra ... nṛ̣ām] TS 185-187 21-24 maitre ... -ābdam] DA $14 \cdot 7$ 


\subsection{General Results of the Ruler of the Year}

Next, Samarasimha states the general results of the ruler of the year [in the Tājikaśāstra]:

If it is joined to or aspected by benefics, free from the sixth, eighth and twelfth houses, [heliacally] risen and endowed with all authority in the nativity, and of similar strength in the year, all of that [year] will be excellent: rulership, strength of body, abundant happiness and attainment of great rank, according to that [annual revolution] and in accordance with the planet in the nativity.

The meaning is as follows: if the ruler of the year occupies a good place in the nativity, aspected by benefics, then the good results of the year are unimpaired. If it occupies an evil place and so on, aspected by malefics, then unimpaired evil results should be predicted; if things are mixed, the results [too] are mixed. In Täjikasāra [185-187 it is said]:

If the ruler of the year is a benefic and occupies an angle, a trine, or the eleventh house, then the entire year is pleasant; if it occupies the sixth, eighth or twelfth house without strength, it is said by the great sages to give evil [results]. The rulers of the munthahā, the year, the eighth house and the ascendant of the year being endowed with strength, not [heliacally] set, make a pleasant year, gain of happiness and wealth, and delights; if it is opposite, [they give] the reverse. Now, when the ruler of the year is a malefic planet occupying the third, sixth or eleventh house in strength, all is good; but if the ruler of the year occupies the twelfth or eighth house, then sages declare no good for men.

Now, Tejaḥsiṃha states a special rule [in Daivajñālaṃkṛti 14.7, 9; 28.6]:

Occupying a friendly, benefic or its own division, leaving out the eighth, twelfth and sixth houses, being victorious, standing in the north, aspected by or joined to friends and benefics, free of the sun, the ruler of the year bestows every comfort throughout the year. 
vakre 'bdape 'bdajanușor api sarvakārye syāt prātilomyaviphalatvadhanakșayādyam | aste hate 'pi ca tad eva tathaiva lagnanāthenthihādhipadaśāpatayo vicintyāh $\|$ janmābdayor api hate 'bdadaśādhipe 'ri-

randhrāntyage 'bdam asad anyaśubhe 'piyoge |

abdadaśādhipo varșeśaḥ|

varșeśvaro muthaśilī ca bhaved yadaukonāthena tatsadanadhātuphalam dadāti $\mid$ ramyam virūpam api vīryavaśāt tayos tadbhāvekșaṇāc ca paricintya dhiyābhidheyam \|

atra varșeśo varṣalagnādhīśena muthaśilaṃ karoti varṣalagnādhīśo vā balavān tadā bhūpāt sukhaṃ vācyam | tathā varșeśo varșalagnapena sahesarāphayogam karoti varșalagnapo vā hīnabalas tadā bhūpād asukhaṃ vācyam | uktaṃ ca jīrṇatājike |

varșalagneśvaro bhūpaḥ senānisś candrasūryapaḥ| muthahädhipatir mantrī pureśo janmalagnapạ̣ \| rasasasyādidhātūnām tanos trairāśikeśvaraḥ| balavadbhir imais tebhyạ subham hīne tad anyathā || iti | tejaḥsiṃhạ |

1 'bdape 'bda] thavābda B N KT M || januṣor] jenuṣor B || api] asi G 2 prātilomya] scripsi; prāṃtyalomya B G K T; prāṃtyalemya N; prātyalomya M 4 nāthenthihādhipadaśāpatayo] nāthoṃthihādhipatayor B; nātheṃthihādhipatayor $\mathrm{N} \quad 5$ 'bda] bdapa $\mathrm{G} \|$ daśādhipe] daśādhipo B 6 'bdam asad] bdasamad N 8 yadauko] scripsi; yadaiko B N G K T M 10-11 tadbhāvekṣaṇāc] tad dhi vikṣaṇāc K 11 dhiyābhidheyam] dhiyā vidheyam K T M 12-13 varṣa ... varșeśo] om. B N 13 tathā] yadā G 13-14 sahesarāpha] sarāpha N 14 varṣa] om. K T M \| balas] tāvān add. B N || bhūpād] nụpād G || asukhaṃ] sukhạ̣ B N 16 senānīś] senānī B N G 18 tanos] tavos $\mathrm{G}$

1-4 vakre ... vicintyāḥ] DA 14.9 $\quad$ 5-6 janmā ... yoge] DA 28.6 8-11 varșeśvaro ... -dheyam] DA 14.10

8 yadauko] The emendation, required by the context, is supported by MS DA1. 
If the ruler of the year is retrograde both in the year and in the nativity, there is contrariety, futility and loss of wealth in every undertaking. If it is [heliacally] set or afflicted, [the result is] the same. The ruler of the ascendant [of the year], the ruler of the inthiha $\bar{a}$, and the ruler of the period should be considered in the same way.

If the ruler of the period of the year is afflicted both in the nativity and in the year, occupying the sixth, eighth or twelfth house, the year is bad, even if the configuration is good in other [respects].

'The ruler of the period of the year' [means] the ruler of the year. [Continuing from Daivajñālamkrtiti 14.10:]

And when the ruler of the year has a mutthasila with the ruler of [any] house, it gives the results of the substance of that house, pleasing or ugly in accordance with the strength of both [planets] and according to the aspects on that house. One should pronounce after considering [the matter] intelligently.

Here, [if] the ruler of the year makes a mutthasila with the ruler of the ascendant of the year, or the ruler of the ascendant of the year is strong, then happiness from the king is to be predicted. Likewise, [if] the ruler of the year makes an isarāpha configuration with the ruler of the ascendant of the year, or the ruler of the ascendant is of little strength, then unhappiness from the king is to be predicted. And it is said in the Jìrnatäjika:

The ruler of the ascendant of the year is the king; the ruler of the sun [or] moon is the commander of the army; the ruler of the munthaha $\bar{a}$ is the counsellor; the ruler of the ascendant of the nativity is the governor of the city; the triplicity ruler of the ascendant is [the custodian] of water, grains and other commodities. By these [planets] being strong, good [will come] from those [persons]; if [the strength] is poor, the reverse.

[And] Tejaḥsiṃha [says in Daivajñalaṃkrti 14.11, 8; 28.5, 8, 9-10, 11]: 
sambhūtilagnamuthahābdavilagnanāthā varșeśavad vihitasaumyakhagetthaśālāḥ| susthānagāḥ śubhadriśaś ca suhrtsvasaumyavarge gatā hy udayinah phaladās tadā syuh || pūrnạm phalam tu paripūrnabale 'bdanāthe madhye ca madhyam iha hinabale ca hinam | naștam samastam api naștabale sadā syād dauhsthyādhirukprabhrtikaștaphalam vinaște \| sūrye 'bdape 'bdajanușoś ca śanau ca dagdhe vakre 'bale viphalatā nikhilakriyānām \| yadbhāvapas tanubhujābdabhujāthavetthaśâlì balì bhavati tatra phalam taduttham | kendre 'dhikārasahito 'bdapatir vipāpah svīyādhikāraphaladaḥ sabaloditaś ca \| yadbhāvago januși saumyakhago 'bdake 'pi tadbhāvago yadi tadā khalu tatphalam syāt | janmābdalagnamuthahābdabhujoditāś ca vīryādhikā yadi tadābdam atīva ramyam || iti |

atha varṣeśādīnām avasthā hillājenoktāḥ |

dīpto dīnaḥ svastho muditaḥ suptaḥ prapīditaś caiva |

parihīyamānaviryah pravrddhaviryo 'dhiviryaś ca \| svoccasthah kila dīpto dainyam punar eti nīcabhavanasthah | svasthah svabhavanasamstho mitrakșetrāśrito muditah $\|$ ripurāsigataḥ supto grahābhibhūtaḥ prapiḍitaś caiva | ravikiranamușitadīptị khacarah parihīyamānavīryaś ca \| svanīcabham atikrāntah svoccābhimukhah pravrddhavīryah syāt |

2 -vad] scripsi; tad B NG KTM 3 su-1 $\left.^{1}\right]$ sva BNGKT 4 varge] varșe BN || phaladās tadā] phaladāḥ sadā G; phaladās sadā K T M $\quad 5$ tu pari] om. K M \| bale] va B 8 kașța] varșa B N; neșța K T M 9 śanau] pānau B N 11 bhāvapas] bhāvas B; bhāvagas N || bhujābda] om. B 12 balī] om. N || tatra] tan na N 14 svīyā] sīmā G 17 lagna] janu B N 18 iti] om. B N 19 varṣe] varthe $\mathrm{N} \quad 21$ 'dhivīryaś] vivīryaś K T M 22 punar eti] purapureti $\mathrm{K}$ 25 muṣitadīptiḥ] muṣitaḥ B; mukhitadīptīḥ G 26 nīcabham] scripsi; nīcam B N G K T M

1-4 sambhūti ... syuh] DA 14.11 $\quad$ 5-8 pūrṇaṃ ... vinaștẹ] DA 14.8 $\quad$ 9-10 sūrye ... kriyānāām] DA $28.511-12$ yad ... uttham] DA 28.8 13-16 kendre ... syāt] DA 28.9-10 17-18 janmā ... ramyam] DA 28.11

2 -vad] The emendation, required by the syntax, is supported by ms DA1. 3 su-] The emendation, required by the context, is supported by MS DA1. 17 bhujoditāś] Possibly an instance of double sandhi for bhujaḥ uditāś. 
Like the ruler of the year, the rulers of the ascendant of the nativity, the munthaha, and the ascendant of the year will give [good] results when forming itthaśâlas with benefic planets, occupying good places and aspected by benefics, occupying friendly, their own, or benefic divisions, and rising [heliacally].

The result is full if the ruler of the year has complete strength, middling if [its strength is] middling, and poor if poor; but if its strength is lost, all will always be lost, [and] if [the ruler of the year] is corrupt, there are evil results such as uneasiness, anxiety and illness.

If the sun is ruler of the year and Saturn is burnt, retrograde or weak in the year and in the nativity, there is futility in every undertaking. ${ }^{32}$

If the strong ruler of any house has an itthaśa la with the ruler of the ascendant, or else with the ruler of the year, it produces its results in that [year].

The ruler of the year in an angle, endowed with authority, without the malefics, strong [and heliacally] risen, gives the results of its own authority. If a benefic planet occupies the same house in the year as it did in the nativity, then certainly its results will come to pass.

If the rulers of the ascendants of the nativity and of the year, of the munthaha $\bar{a}$, and of the year are [heliacally] risen and of great strength, then the year will be exceedingly pleasant.

Next, the conditions of the ruler of the year and other [planets] are described by Hillāja:

[1] Blazing, [2] wretched, [3] confident, [4] happy, [5] sleeping and [6] tormented, [7] decreasing in strength, [8] increasing in strength, and [9] of great strength. [A planet] occupying its exaltation is 'blazing', and one occupying its sign of fall becomes 'wretched'; one occupying its own domicile is 'confident'; one placed in the domicile of a friend, 'happy'. One occupying the sign of an enemy is 'sleeping', one vanquished by [another] planet is 'tormented', and a planet robbed of its light by the sun's rays is 'decreasing in strength'. One having passed beyond its sign of fall and approaching its exaltation is 'increasing

32 Saturn being combust or 'burnt' implies that it is conjunct the sun, but the connection between the sun and Saturn in the other cases is not clear. In independent witnesses of the Daivajñălamkrti, the preceding half-stanza refers to Saturn occupying the tenth house, giving some context for the statement about actions or undertakings. 
svāmśakasaṃsthah saumyair vilokyamāno 'dhiviryaś ca || dīpte dīptir anuttamā narapater dīne ca dainyāgamah svasthe svātmamanahsthitam ca bhavati śrīkïrtisaukhyādikam | āmodo mudite yathepsitaphalaprāptih prasupte vipat pị̣ā śatrukṛtā prapịditatanau mauḍhyam gate 'rthakșayah \|

bhavati pravrddhavirye gajaturagasuvarnaratnāptih | tadvad adhiviryayukte bhuktitrayasampadādikaṃ rājñah \| varșeśo lagnapatih svadaśádhiśaś ca yadgunopetah | tadgunaphalam ca varșe nirdeśyam khattakhuttamatam etat || iti |

atha varșeśamūsariḥphaphalam varṣatantre |

śubhesarāphe śubham asti kiṃcid aniștam evāśubhamūsariḥphe | iti |

viśeșāntaram āha samarasiṃhaḥ |

yo bhavati varșanāthas tasmin varșe daśādhipah sa iha | kam paśyed atha cakre kvāste janmani ca varșe ca \| krūrah śubho 'thavāyam kena ca drșțo yutah sa kasya gṛhe | kendre tannikațe vā samagatir uditah kimadhikärah || ittham avalokite 'smin śubhayutadrște vilagnagaganasthe | sarvaṃ śubham svaparikaramadhye prādhānyam āviśati madhyabale 'smin madhyam hìne hīnam gṛarkșabhāvena | samyag vilokya jātakahāyanalagne phalaṃ nigadet | varșasvāmini mande patite vibale nirāśatādauhsthye || iti |

1 samsthah] sthah B N 2 dīpte] dīpto B N $\|$ dīne] hīne K T M 4 prasupte] prasupto B N G 5 mauḍhyaṃ] meșaṃ N; moșam G 7 bhuktitraya] bhuktyatra B N; muktitraya K T M 9 khattakhuttamatam] khantukhuttam B; khatakhantam N; svatamuttamatam K M 10 atha] om. B N 13-14 sa iha | kaṃ] scripsi; sa iha tam B N; sa iha || tam G; sadgṛhagata K T; sadgṛhagaṃ M 14 kvāste] kāste N 15 'thavāyaṃ] 'thavāye G \| sa] om. T 17 avalokite] avalokito G \| dṛsțe] dṛsțam B N T 18 parikara] paripāka G T 19 hīne] om. K T 20 nigadet] nigaditam B N 21 patite] vitite $\mathrm{N}$ a.c.; tite N p.c. \| dauhsthye] dausthe B N K T M

11 śubhesarāphe ... mūsariḥphe] VT 1.38 
in strength', and one occupying its own division, being aspected by benefics, is 'of great strength'.

When [a planet] is blazing, there is unsurpassed splendour from the king; when it is wretched, the arrival of wretchedness; when it is confident, grace, renown, happiness and so on abide in one's heart and mind; when it is happy, there is joy and the attainment of desired results; when it is sleeping, misfortune; when it is tormented in body, torments caused by enemies; when obscured [by the sun], loss of wealth. When it is increasing in strength, there is gain of elephants, horses, gold and jewels; likewise, when it is endowed with great strength, the blessing of threefold pleasures and so on from the king. With whatever virtues the ruler of the year, the ruler of the ascendant and the ruler of one's [current] period are invested, the result of those virtues should be predicted: this is the view of Khattakhutta.

Next, the results of a müsarihpha with the ruler of the year [are described] in Varșatantra [1.38]:

When the isarāpha is with a benefic there is some good, [but] only evil if the müsarihpha is with a malefic.

Samarasiṃha states another special rule [in the Täjikaśāstra]:

[The planet] that becomes ruler of the year is the ruler of the period of that year. What [planet] does it aspect here, and where in the circle does it dwell, in the nativity and in the year? Is it a malefic or a benefic, aspected by or joined to whom, and in whose domicile is it? [Is it] in an angle or near one, ${ }^{33}$ direct in motion, [heliacally] risen, and what authority does it have? This [ruler] having been examined thus, if it is joined to or aspected by benefics, in the ascendant or the midheaven, all is good, and [the native] becomes foremost among his peers. When it is of middling strength, [the good results are] middling; when [the strength is] poor, [the results are] poor, according to the nature of the house and sign. One should declare the result after thoroughly examining the horoscopes of the nativity and the year. If the ruler of the year is slow, ${ }^{34}$ corrupt and weak, [there is] despair and uneasiness.

33 That is, in a succedent house.

34 Or: 'is Saturn'. 
varșatantre |

yo janmani phalaṃ dātum vibhur mūsaripho 'sya cet | abdalagnābdapabhavas tasminn abde na tatphalam \| vyatyāse phalam ādeśyam itthaśāle viśeșataḥ| nobhayam cet tadāpy asti janmāśrayam iti sphuțam \|

ayam arthạ̣ | janmani pañcameśo gurụ̣ pañcamabhāvaṃ paśyati tatra vā bhavati | tena putraprāptikaro jātah | punar yasmin varṣe gurudaśā tasminn eva varṣe varșalagneśavarșeśayor īsarāphayogo guruṇā saha jātas tadā tasmin varṣe putraprāptir na vācyā | vyatyāse dīptāmśātikrameṇa musariḥphayogābhāve itthaśāle vā phalaṃ vācyam | dṛṣtỵabhāvatvāt ittha10 śālamūsariḥphayogayor abhāve janmakālāśrayeṇa putraprāptir vācyā iti |

hadde yādṛśi yaḥ kheța ādhatte 'tra ca yo mahạ̣| janmany abde ca tādṛtve tadātmaphaladas tv asau \|

ayam arthah | janmani yo grahạ̣ svīyahaddādiyutas tasmin yo graho muthaśîlena tejo nikṣipati | tasmin grahe varṣakāle 'pi tādṛśi sati | ko 'rthah | varșe tasyām eva haddāyāṃ sa eva graho muthaśilaṃ karoti tadā sa varṣe krūrasaumyabalābalādivivekenātmaśubhāśubhaphalado bhavati | atrodāharaṇam uktam tatraiva |

abdeśvaro gurur mitrahadde mitradriśā śaśī | maho 'trādhād amūdṛk sa varșe 'bdas tena śobhanaḥ \|

3 bhavas] kṣavas G $\quad 5$ sphuțam] sphuțaḥ B N 8 isarāpha] itisarāpha B N || yogo] yoge N 10 dṛsțtyabhāvatvāt] iștyavācatvāt B N; om. G 11 abhāve] avābhe N 12 kheța] khevṛ N 13-14 janmany ... grahạ̣] om. B 13 tādṛktve] tādakte N 16 tasyām eva] tasyābhāve ca B N G 19 gurur] guror G 20 amūdṛtk sa] amūdṛkata N

2-5 yo ... sphuțam] VT 1.40-41 12-13 hadde ... asau] VT 1.39 19-20 abdeśvaro ... śobhanah] VT 1.43 
[And] in Varșatantra [1.40-41, it is said]:

If [a planet] which [by its condition] in the nativity is able to give a [certain] result has a müsarihpha with the ruler of the ascendant of the year or the ruler of the year, its result will not [manifest] in that year. In the opposite [situation], the result should be predicted, particularly in case of an itthaśâla. If there is neither [mūsarihpha nor itthaśāla], then clearly [the result] depends [solely] on the nativity.

The meaning is as follows: in the nativity, Jupiter, ruler of the fifth, aspects the fifth house or is in it. Thereby he becomes able to make [the native] have children. Then, when the period of Jupiter occurs in a year, in that same year the ruler of the ascendant of the year or the ruler of the year forms an $\bar{s} a r \bar{a}-$ pha configuration with Jupiter: then having a child in that year should not be predicted. ${ }^{35}$ In the opposite [situation, that is], in the absence of a müsarihpha configuration due to [the aspect angle] exceeding [the planets'] orbs of light, or in case of an itthaśāla, the result should be predicted. In the absence of both itthaśâla and müsarihpha configurations due to the absence of any aspect, having children should be predicted depending [only] on [the configurations at] the time of the nativity. [Continuing from Varșatantra 1.39:]

In whatever sort of haddā a planet is, or whichever [planet] directs its light there in the nativity, if it is the same in the year, then that [planet] will give its own results.

The meaning is as follows: a planet which in the nativity is joined to a hadd $\bar{a}$ belonging to itself and so on, and a planet which casts its own light there by mutthasila - if that planet is [placed] like that even at the time of [the revolution of] the year. What does that mean? [If] that same planet makes a mutthaśila in that same haddā in the year, then in [that] year it will give its own good or evil results, in accordance with the consideration of [its nature as a] malefic or benefic, [its] strength or weakness, and so on. An illustration of this is given in the same place [Varșatantra, 1.43]:

Jupiter is ruler of the year, in a friendly haddā; the moon directs its light there with a friendly aspect; [and] he is of such a kind in the year: thereby the year [becomes] good. 
ayam arthạ | janmani mitrahaddāsthaguruṇā snehadṛsțyā candra itthaśālaṃ karoti | varșe 'pi varșeśvaro gurur amūdṛk nāma etādṛśạ | ko 'rthạ | mitrahaddāsthah snehadṛṣtyā candretthaśālavāṃś ca | tena guroh śubhaphalādhikyād varṣaḥ śobhana ity arthaḥ | anyo 'pi viśeșas tatraiva |

janmābdāngapatīnthihāpatisamānāthādyadhīkāravān

sūryo naștabalas tvagakșivilayaṃ kuryān nirutsāhatām |

nīcatvam pitrmātrtrto 'py abhibhavam candre 'kșikāryakșayo

dāridryaṃ ca parābhavo gṛhakalir vyādhyādhibhītis tadā $\|$

bhaume calatvam bhïrutvam budhe mohaparābhavau |

jōve dharmakșayah kaștaphalājivinavorttayah \|

śukre vilāsasaukhyānām nāsán strïbhị samam kalị̣| saure bhrtyajanād duhkham rujo vātaprakopatah || iti |

naștabalaḥ pañcavargyā pañcaviṃśopakanyūnabala iti |

atha sūryādigrahasādhāraṇyenottamamadhyamanikṛsțabalayutasyābdapasya phalam varșatantre | tatrādau raviphalam |

sūrye 'bdape balini rājyasukhātmajārtha-

läbhah kulocitabhavah parivārasaukhyam |

puștam yaśo gṛasukham vividhā pratișthā

śatrurvinaśyati phalam janikhețayuktyā ||

1 haddāstha] haddāsthạ̣ B N G $\quad$ 1-2 candra itthaśālaṃ] candretthaśālan T $\quad 8$ g̣̣ha] graha $\mathrm{G}$ \|| vyādhyādhi] vyādhyādi K M 9 calatvaṃ] valatvam K T; balatvam M 10 phalā-] phalāj T M 13 pañca ${ }^{2}$ ] om. K T M 16 sūrye] sūryo M 17 bhavah] bhuvaḥ B N G

5-12 janmā- ... prakopataḥ] VT 5·3-5 16-19 sūrye ... yuktyā] VT 1.15 
The meaning is as follows: in the nativity, the moon makes an itthaśăla by friendly aspect with Jupiter, which occupies a friendly hadd $\bar{a}$; and in the year, Jupiter, ruler of the year, is 'of such a kind', that is, similar to this. What does that mean? Occupying a friendly haddā and having an itthaśăla with the moon by friendly aspect. 'Thereby' - from the abundance of Jupiter's good results - 'the year [becomes] good'. This is meant. In the same [work, Varșatantra $5 \cdot 3-5$ ], there is another special rule:

The sun having lost its strength and holding the office of ruler of the ascendant of the nativity or the year, ruler of the inthiha, ruler of the year and so on causes deterioration of the skin and eyes, inertia, inferiority, subjugation of ${ }^{36}$ one's father and mother; if the moon [holds office having lost its strength], then there is failure of eye[sight] and of undertakings, poverty, humiliation, domestic strife and danger of illness and anxiety. If Mars, there is fickleness and cowardice; if Mercury, bewilderment and humiliation; if Jupiter, loss of merit and earning one's livelihood with hardships; if Venus, loss of delight and pleasures, and quarrels with women; if Saturn, suffering on account of servants and illness from agitation of [the humour of] wind.

'Having lost its strength' [means] having a strength of less than five in the twenty-point scheme of the five dignities.

\subsection{The Results of Each Planet as Ruler of the Year}

\subsubsection{The Sun as Ruler of the Year}

Next, the general results of the sun and other planets as rulers of the year endowed with excellent, middling or poor strength [are described] in the Varșatantra; and first, the results of the sun [1.15-17]:

If the sun as ruler of the year is strong, [there is] gain of dominion, happiness, children and wealth as befits one's family community; enjoyment of retinue; wide renown; domestic happiness; eminence of various kinds; [the native's] enemy is destroyed. The results [should be understood] in accordance with the planets in the nativity.

36 Or, possibly, under. 
ayam arthạ | varșeśo janmani satsthānagaḥ svoccādigaḥ śubhagrahāvalokito bhavati tadā śubhaphalam avikalaṃ syāt | vaiparītye 'śubhaphalaṃ miśratve miśraphalam iti |

madhye ravau phalam idam nikhilam tu madhyam

svalpam sukham svajanato 'pi vivādam ähuḥ|

sthānacyutir na ca sukham kṛśatāpi dehe

bhïtir nrpān muthaśilo na subhena cet syāt \|

atra raveh śubhagraheṇa sākaṃ muthaśilayoge aśubhaphalālpatā jñeyeti |

sūrye balena rahite 'bdapatau videśa-

yānam dhanakṣayaśuco 'ribhayaṃ ca tandrā |

lokāpavādabhayam ugrarujo 'tiduhkham

pitrādito 'pi na sukham sutamitrabhïtị \|

tejahsimho 'pi |

sadmoccamukhyaparipūrṇabale 'bdape 'rke

prāptį̣ kulocitapadasya punaḥ pratișthā |

sthānacyutau bhavati bhüdhanakìrtimitra-

lābho' 'rivargavijayādi vapuhsukhāni $\|$

haddādrkānakanavāmśakamukhyamadhya-

vīrye tu madhyam akhilam phalam àdimam syāt |

nīcādinā gatabale ca vinaștadagdhe

rogādhidūragatidauhsthyajanāpavādāḥ \|

1 sat] san M \|| grahā] gṛhā N G 2 avikalaṃ] api viphalạ̣ M 14 'bdape 'rke] bdapekṣarke G 15 padasya] pasya N 16 sthānacyutau] scripsi; sthānācyuto B N G; sthānacyuto K T M 17 lābho 'ri] scripsi; lābhāri B N G K T M 18 dṛkāṇaka] dreṣkāṇaka B N G \| mukhya] mukham B N G 21 rogādhi] bhīr ādhi B N G a.c. \| dūra] dūtara G

4-7 madhye ... syāt] VT 1.16 9-12 sūrye ... bhītiḥ] VT 1.17 14-21 sadmocca ... vādāh ] DA $15.1-2$

16 sthānacyutau] The emendation is supported by MS DA1. Cf. also the highly similar quotation from the TS immediately following (likely derived either from an early witness of the DA or from a common source). 17 lābho 'ri] The emendation is supported by MS DAı. 
The meaning is as follows: [if] the ruler of the year occupies a good place, in its exaltation and so on, aspected by benefic planets, then the good results are unimpaired; if the opposite, [there are] evil results; if it is mixed, mixed results.

If the sun is middling [in strength], all these results are middling; [astrologers] declare little happiness and quarrels with one's own people; there will be a fall from position and no happiness, gauntness of body and danger from the king, if there is no mutthaśila with a benefic.

Here, if the sun has a mutthaśila configuration with a benefic planet, the evil results should be understood to be slight.

If the sun as ruler of the year is bereft of strength, there is travel abroad, ${ }^{37}$ loss of wealth, sorrows, danger from enemies, and lethargy; danger of slander by [common] people, terrible illnesses, great suffering, no happiness from one's father and so on, and dangers to ${ }^{38}$ children and friends.

And Tejaḥsiṃha [says in Daivajñālaṃkrti 15.1-2]:

If the sun as ruler of the year is abounding in the strength of domicile, exaltation, and so on, there is attainment of rank befitting one's family community, and eminence; by change of place, there is gain of land, wealth, renown and friends, victory over enemy forces and so on, and pleasures of the body. If [the sun is] of middling strength by [dignities of] haddā, decan, ninth-part, and so on, all the foregoing results will be middling. If [the sun] has lost its strength by fall and so on, is corrupt and burnt, ${ }^{39}$ there is illness, ${ }^{40}$ anxiety, distant journeys, uneasiness and slander by people [in general].

37 Not, in this cultural context, undertaken for pleasure, but more likely as a last resort in difficult circumstances, and understood to be fraught with hardships and danger.

38 Or, possibly, from.

39 For a planet to be 'burnt' or 'combust' (dagdha) normally means being heliacally set, that is, too apparently close to the sun in the sky to be visible. It is not clear what the term is intended to convey when applied to the sun itself; possibly it is used simply as a synonym of 'afflicted'.

Text witnesses B N read 'fear'. 
tājikasāre 'pi |

abdādhipe 'mbaramañau sabale pratișthhā-

prāptis tato nijakule bahurājyalābhah |

sthānāntarād bhavati bhūdhanakìrtimitra-

lābhas tathā bahusukhāni ripor vināśạ \|

putrān nrpāt svajanato 'lpasukhaṃ narāṇām

syān madhyavīryasahite dyumaṇau daśāyām |

kuryād aritvam api rogabhayaṃ vivādam

lokais tathā nrrpajanaih saha cāpi vairam \|

naște ravau bhavati vairijanād virodho

rogāgamo nrpajanād bhayam ugrakam syāt |

dravyakșayaś ca sutatah kalahạ svamitrād

dagdhe ca dūragatidauḥsthyajanāpavādāḥ \|

atha viśeșaphalaṃ hāyanasundare |

varșasvāmī yadā sūryas tadvarșe saṃsthito 'pi vā |

pūrṇam paśyati vā varșe tadā rājabhayam bhavet \|

jvaraḥ pittabhramo vā syād dhānir vā pürvadeśatah |

dhāturyāpārato hānir virodho mitrabāndhavaih \|

viyogo deśagamanam yadi candramasā yutaḥ |

pūrṇadrșto 'tha śatrūnām jetā dravinalābhadaḥ $\|$

vāyavyottarato labdhị saukhyam tejovivardhanam |

sadyogatā mitrasangah strīsañgāt sukham āpnuyāt \|

śvetakrayānakāal lābho viśeșāt kalapattanāt |

śayanāśanavastrādi mișțānnasvādubhojanam \|

saudhotsangasthito gitanrtyalolupamānasah $\mid$

strīvatsalạ̣ sugandhāḍyo rātrau sukhitacetasaḥ \|

śleșmakopạ̣ kvacit kāle vāntir vā bhavati dhruvam |

5 vināśaḥ] vināśam B N G 8 aritvam] daridratvam B N G; daritvam K 12 sutatah] sasutaḥ B N; sutaḥ N 13 dauḥsthya] sva B N 14 atha] atra K T M 15 sūryas tad] sūrya sa B N G 18 dhātu] dhātur B N G 20 dṛștọ] dṛsțe K T M \|| 'tha] pa B N \| jetā] tejā N G 21 labdhiḥ] vyādhiḥ B N G a.c. 22 sadyogatā] sadyogatir B N G 23 viśeșāt] viśeșā B N G \| pattanāt] scripsi; pattanā B N G; pattanam K T M 24 śayanāśana] śamanāśana G p.c. ॥ miștānnna] bhiștānnna K || bhojanam] bhojanaḥ B N G 26 sugandhāọhyo] sugandhādyo B $\mathrm{N}$

2-13 abdā- ... -vādāh] TS 104-106 15-488.5 varșa ... raviḥ] HS 105-125 
And in Täjikasāra [104-106 it is said] $:^{41}$

If the sun as ruler of the year is strong, there is attainment of eminence, and gain of great dominion in one's own family community. There is gain of land, wealth, renown and friends from another place; also many pleasures and destruction of the enemy. Men will have little happiness from sons, the king or their own people when the sun in its period is endowed with middling strength. ${ }^{42}$ It creates hostility, danger of illness, quarrels with people [in general], and likewise enmity with princes. If [the strength of] the sun is lost, there is conflict with enemies, onset of illness, and there will be terrible danger from princes; loss of wealth on account of children; quarrels with friends; and if burnt, distant journeys, uneasiness and slander by people [in general].

Next, detailed results [as described] in Hāyanasundara [105-125]:

When the sun is ruler of the year, or occupying that year, or fully aspecting the year, ${ }^{43}$ then there is danger from the king, or there will be a fever or a disorder of bile, or loss [arising] from the east, loss from business [involving] minerals, and quarrels with friends and relatives.

There is separation and travel to [another] country if [the sun is] joined to the moon or fully aspected [by it]: it will vanquish enemies and give gain of property. There is gain from the northwest and north, happiness and increase in vigour, good fortune and the company of friends; [the native] derives happiness from the company of women. There is gain from trade in white articles, in particular from Kalapattana; ${ }^{44}$ beds, food, clothes, and eating sweetmeats and [other] tasty [foods]. [The native] lives in a stuccoed [house], his heart eager for song and dance, indulging in women, well-perfumed, happy in his mind at night. Sometimes, indeed, there is agitation of phlegm or vomiting.

41 These verses, in the same metre as the foregoing quotation from the Daivajña alamkrti and with several long phrases repeated verbatim, suggest a direct influence from the former work on the Täjikasāra, authored about half a century later.

42 That is, when the sun is ruler of the year.

43 Presumably 'year' here refers to the sign of the munthaha, or possibly to the ascendant of the revolution.

44 Probably a port known to ancient Graeco-Roman traders as Camara, near to or identical with present-day Karaikal on the southeast coast of India. 
syād bhaumayutadrșțo 'rko bhaved vidrumaläbhakrt $\|$

svarnalābho yaśolābhah śatrūnām ca parājayaḥ |

rājasanmānam adhikamatih pittaprakopatā \|

syād dakșinadiśo lābho vahnitaskarasādhvasam |

mrșābhayam bhaved bhaumayutadrște ca bhāskare \|

sūryo budhena sahito 'tha nirīkșito 'pi

syāt tadgunah kim api kacchuratā kadācit|

śatror bhayam bhavati kiṃcana kaștam iștair

vidveșitā svasadane 'pi rujārditaḥ syāt \|

yadi guruyutadrștah syād asau candarocị

srjati vitathamārgam pāpamārgam vihāya |

gurupadam atha tìrtham prāpnuyāt putrasaukhyam

nrpakulabahumānyah strīprasangena läbhah $\|$

sajjanaih saha sambandhạ śatrunāśo dhanāgamah |

cittotsāho mano'bhịsțam kāryasiddhir bhaven nṛ̣ām \|

ravir atha sitadrștah samyuto vā jvarārtir

bhavati sirasi pịdā chardir apy eti vāntim |

bhavatijațharaśülam kāsapittātisārai

ripubhayam atha cintā sthānato bhramśam eti $\|$

yadāgneyadiśo lābhah pittakāmaladadrutāḥ|

galah śusyati śukrena ravir drșțo yuto yadi $\|$

śaninā yadi saṃyuto 'tha drșțas tapanas tāpakaro nrṇām ripubhyah |

dhanahānir udāsatodyamāt syād viphalakleśakarah suhrdviyogāt \|

syāe catuṣpadato hānir asitād api mānavāt |

asaukhyaṃ paścimāsáāto hānih śaniyuto ravih \||

rāhunāapy atha yuto yadi drșțo dharmadīdhitir amañgalakartā |

nīcakarmanirato dhanahina h. pịdito bhavati durvyasanena \|

putramitrasahajādipiẹitah kaștam eti sukhahānir adbhutā |

ādhim eti nanu nairṛter diśo mütrakrcchrasadṛśā rujārditah \|

viyogo bandhuvargebhyo vikārāh pịdayanti ca |

1 yuta] nyuta $\mathrm{G} \quad 3$ pitta] pi N; tta $\mathrm{K} \quad 6$ sahito] sahite $\mathrm{N} \quad 9$ vidveșitā] vidveșatā B N G 12 putra] yatra G 15 'bhīștam] bhīștạh B N G 16 sita] sati B N G 18 kāsa] kāka B N G; kāśa K T 20 yadāgneya] syād āgneya K T M 21 galaḥ] gataḥ B N G \| ravir] scripsi; ravi B N G K T M 23 hānir udāsato] hāni dāsato K || viphala] viphalaḥ K T M 
Should the sun be joined to or aspected by Mars, it will make gain of ${ }^{45}$ coral; there is gain of gold, gain of renown, and conquest of enemies; honour from the king, excellent comprehension, [but] agitation of bile. There will be gain from the southern quarter, peril from fire and robbers and danger from lies when the sun is joined to or aspected by Mars.

[If] the sun is joined to or aspected by Mercury, [the native] will have its virtue ${ }^{46}$ and sometimes afflictions of the skin; there is danger from an enemy, some evil, hostility with loved ones, and he will be plagued by illness in his own home.

If that sun is joined to or aspected by Jupiter, he abandons the path of falsehood, leaving the path of evil; he will attain the position of preceptor ${ }^{47}$ or a sacred place and happiness from children [and be] highly regarded by princely families; there is gain by connections with women. Men will have association with good people, defeat of enemies, acquisition of wealth, strength of mind, the heart's desire, and success in undertakings.

If the sun is aspected by Venus or conjoined [with it], there is suffering from fever, headache and nausea, and [the native] vomits. There is stomach pain from cough, bile and diarrhoea, danger from enemies and anxiety, [and the native] loses his place. While there is gain from the southeastern quarter, there is [also] bile, jaundice and skin disease; the throat dries up if the sun is aspected by or joined to Venus.

If the sun is joined to or aspected by Saturn, it makes afflictions for men from enemies; there will be loss of wealth and apathy from exertion; [the sun] makes troubles in vain due to separation from friends. There will be loss due to quadrupeds and black men, unhappiness and loss from the western quarter [if] the sun is joined by Saturn.

And if [the sun] is joined to or aspected by Rāhu, there is religious reflection [but the native] acts unpropitiously: he is given to low acts, bereft of wealth, tormented by evil passions. Tormented by ${ }^{48}$ children, friends, brothers and so on, he suffers misery; his loss of happiness is astounding. He suffers anxiety from the southwestern quarter [and is] plagued by illnesses like strangury. There is separation from his group

45 Or, possibly, from.

46 Presumably wisdom or learning, reflecting the Sanskrit name of Mercury (budha).

47 Or: the feet of his preceptor. Seeking refuge at someone's feet is a common way of expressing submission.

48 Or: on account of. 
nìcasañgarato nityam rāhuṇā samyuto ravịh $\|$

ketunā yutadrșto 'rkah sthānabhramśam avāpnuyāt |

bandhumitrakrtā pịdā tv audāsyam śocanìatā \|

hānir nīcajanāt krșṇamanujenārdito bhavet |

sarvāśubhaphalam datte ketunā saṃyuto ravih \|

iti sūryaphalam ||

atha candraphalam varșatantre |

vīryānvite śaśini vittakalatraputra-

mitrālayādivividham sukham āhur āryāḥ|

sraggandhamauktikadukūlasukhānubhütir

lābhạ kulocitapadasya nrpaih sakhitvam \|

varșādhipe śaśsini madhyabale phalāni

madhyāny amūni riputā sutamitravarge |

sthānāntare gatir atho kriśatā śarīre

śleșmodbhavaś ca yadi pāpakrtesarāphaḥ \|

naște 'bdape śaśini śítakaphādirogaś

caurādibhịh svajanavigraham apy uśanti $\mid$

dūre gatị̣ sutakalatrasukhātyayaś ca

syān mrtyutulyam atihinabale śaśāinke \|

tejaḥsiṃhena candraphalaṃ sūryavad uktam | tājikasāre 'pi |

varșādhipe himarucau paripūrnavīrye

vittāgamo nrpajanān nrpater dhanāptih |

saukhyāni cātra vividhāni kalatraputra-

śvetādivastuvaśatah prakaroti lābham \|

madhye vidhur nrpajanān nrpater virodham

vittakṣayam svajanatah prakarotivairam |

strīvargatah satatam alpasukham krśatvam

vairägyaduhkhajananam bhayam ugrakaṃ ca \|

3 tv audāsyaṃ] saudāsyaṃ K M; tyaudāsyam T 4 hānir] api B N G || kṛ̣ṇa] kṛșța G p.c. N 5 sarvāśubha] sarvaṃ śubha T 12 varșādhipe] varșādhipạ̣ K T \|| śaśini] rāśini K; saśini $T$ 18 sukhātyayaś] sukhāptayaś M 25 madhye] madhyo K T M

8-19 vīryānvite ... śaśāṅke] VT 1.19-21 21-49o.4 varṣā- ... pāke] TS 107-109 
of kinsmen, and diseases torment [him; he is] constantly addicted to low company [if] the sun is joined to Rāhu.

[If] the sun is joined to or aspected by Ketu, [the native] will lose his place; there is torment caused by kinsmen and friends, apathy, a lamentable condition and loss due to low people: he will be plagued by a black man. Joined by Ketu, the sun gives all evil results.

This concludes the results of the sun.

\subsubsection{The Moon as Ruler of the Year}

Next, the results of the moon [are described] in Varșatantra [1.19-21]:

If the moon is endowed with strength, noble [astrologers] declare manifold pleasures of wealth, wife, children, friends, houses and so on: there is enjoyment of garlands, perfumes, pearls and fine cloth, attainment of rank befitting one's family community, and friendship with princes. If the moon as ruler of the year has middling strength, these results are middling; there is enmity with one's children or circle of friends, leaving [home] for another place, gauntness of body and excess of phlegm if a malefic makes an isaräpha [with the moon]. If the moon as ruler of the year has lost [its strength], there is illness from cold, phlegm and so on, danger from robbers and so on, and [astrologers] declare discord with one's own people. There will be distant travel and an end to happiness from wife and children; if the moon is utterly bereft of strength, [a condition] equal to death.

Tejahsiṃha says that the results of the moon are like [those of] the sun. And in Täjikasāra [107-109 it is said]:

If the moon as ruler of the year is complete in strength, there is acquisition of wealth from princes, gain of riches from the king, and manifold pleasures; it makes profit on account of wife, children, and substances that are white and so on. If [its strength] is middling, the moon makes conflict with princes or the king, loss of wealth, enmity with one's own people, little pleasure from women at all times, gauntness, the arising of aversion and suffering, and terrible danger. If [its strength] is lost, 
naște bhayam bhavati vātakaphādipīdā

vairodayo nijakule nrpater virodhah |

sthānāntarād aribhayam tv asukham ca dagdhe

mrtyor bhayam tanubhṛtāị himagau ca pāke \|

viśeșaphalaṃ hāyanasundare |

varșapo yadi candraḥ syāt pūrṇam paśyati varșapam |

varșe vā strīprasaingena manujah sukham edhate \|

kanyāprasūtịh sitavastutah syāl lābhas tathālaṃkaraṇam ca kiṃcit |

svapne yuvatyā saha saingam eti lābhas tu vāyavyadiśo 'pi bhūyāt $\|$

bhunkte 'timadhuram vastrābharañaprāptir uttamā |

kimcit svapakșato vairam lābhah syād uttarādiśah ||

candrah sūryeṇa yuto dṛsto vā rājasamgamam kurute |

kṣāmojvarākșirogau gātre lūtādivisphoțah \|

kiṇcid api vahnitaḥ suranrpavargād bhītim eti sāśañkam |

krudhyaty anusamayam ayam yadi candrah sūryayutadrștah $\|$

bhaumena sahitaś candro drșțo vāgneś catuṣpadāt |

bhayam vidhatte yāmyāto hānị̣ kācijjvaravyathā $\mid$

bhayam ca skhalanād bhümau śastrād rudhiravikriyā |

kāso visphoțakādi syur bhayaṃ hānir athālpikā \|

kṣāmam vapur nrpād dandabhayam syād indraluptakam |

mañgalena yuto drșto 'mangalam kurute śaśî $\|$

budhena yutadrșțo vā rohinīramaṇas tadā

svarnāadidhātusambandhāl lābho vāhanavājinām ||

medhāvrddhir bhogayutah sadānandamayah sukhī|

samakșaripupakșah syāl likhane pațhane bhayam \|

syād uttaradiśo lābhah svajanāt sukham āpnuyāt |

sadā śubhaphalam datte budhena sahitah śaśi $\|$

2 nụpater] ṇ̣patir K T || virodhaḥ] virodham B N G; virodham K T 3 sthānāntarād ari] sthānāntarādi B N $\quad 4$ ca] sva G p.c. K T M $\quad 5$ hāyana] hāna B 6 varṣapam] varșayạ̣ G 8 vastutah] vastugạ̣ B N G \| karaṇaṃ] karaṇaś B N G K T \| kiṃcit] kaścit B N G K T 13 kṣāmo] kṣamo B || jvarākṣirogau] scripsi; jvarākșirogārtair B N G; jvarākṣirogārtau K; jvarākșirogārttau T; jvarāc chirārto M \|| lūtādi] śūlādi K T M 15 krudhyaty] scripsi; kruddhaty B N G K T M || ayam ] ca add. B N G 16 vāgneś] vāgneya B N; vāgne G p.c. 18 bhūmau] bhaume B N G || śastrād rudhira] śastrāt drudhira B N G || vikriyā] vikrayā B N G 19 kāso] kāsaṃ K T 20 vapur] vupur K \| luptakam] lumakaṃ N 21 mangalena] mańgalema $\mathrm{N}$ 23 vājinām] vānināṃ N 25 bhayam] bhayāt B N G 27 budhena] budhema N

6-492.30 varṣapo ... śaśī] HS 126-150

20 indraluptakam] G adds in the margin: vādi khorā. 
there is danger, afflictions of [the humour of] wind, phlegm and so on, the dawning of enmity in one's own family community, conflict with the king, danger from enemies from another place, and unhappiness; if [the moon] is burnt, danger of death for men in the period of the moon.

Detailed results [are described] in Hāyanasundara [126-150]:

If the moon should be ruler of the year or aspect the ruler of the year fully in [the revolution of] the year, a man prospers happily by connections with women. There will be the birth of a daughter, gain from white articles, and some decoration [of the body]; he unites with a woman in his dreams, and there will be gain from the northwestern quarter. He eats the sweetest [foods] and obtains excellent clothes and ornaments; there will be some enmity with his own people [but] gain from the northern quarter.

Joined to or aspected by the sun, the moon brings the company of princes, [but] there is a wasting [of the body], fever and eye disease, and outbreak of skin ailments and so on in his body. He also suffers some danger and anxiety from fire, from gods and princes, and is frequently angry, if the moon is joined to or aspected by the sun.

Joined to or aspected by Mars, the moon gives danger from fire and quadrupeds, loss in the south, and some affliction from fevers. There will be danger of slipping on the ground; corruption of the blood from [injury by] a weapon; cough, boils and so on; fear, and a little loss. The body will be gaunt; there will be danger of punishment by the king and baldness. Joined to or aspected by Mars, the moon makes such misfortunes. 49

[If] the moon is joined to or aspected by Mercury, then there is gain of vehicles and horses by dealings in gold and other metals. There is increase in comprehension, and [the native] enjoys pleasures, ever blissful and happy; [but] he will be brought face to face with his enemies, and there is danger in reading and writing. There will be gain from the northern quarter, and he will derive happiness from his own people. Joined to Mercury, the moon always gives good results.

49 A pun on the word margala 'fortunate, auspicious', used euphemistically as a name of Mars. 
yadi guruyutadrșțas tārakeśo dhanāptim

sukhavasanasutaśrīsadvilāsaṃ vidhatte |

bhavati viśadavidyālabdhir aindrìdiśātặ

kim api ca dhanadāśāto mahālābham eti $\|$

vāhanāptir bhaved bhoktā bhagavaty ativatsalaḥ|

loke mānayaśah svarṇalābhas tūttamasañgatah \|

śukreṇa yutadrșțaś cet tārakādhipatir yadā|

muktābharanabhūṣādilābhaḥ śvetakrayānakāt \|

jagadīsvarapadabhakto lābho jalajātavastutah satatam |

sukham eti strīsañgāt kanyāsūtiḥ striyo lābhah \|

syād āgneyadiśah saukhyam lābhah punyavivardhanam |

gìtād uttamavastrādiśayanāsanabhojanam \|

syād uttamagatiprāptiḥ savilāsaḥ sahoditaḥ|

sugandhadivyavastrādi labhate manujottamah $\|$

saurinā yutadrștendur udvegam kurute bhayam |

nrpaśatrubhayāc chokam hāniṃ vā vāruṇidiśah $\|$

kānāat pangor alpalābho dhananāśo bhayam bhavet |

gātre raktavikāreṇa dadrur nīcena saṃgatih \|

kuțumbamadhye kalaho durbuddher vyasanāgamaḥ |

krśatā gātrasaṃkocah śaniyuktah śaśíyadi $\|$

syāt tamoyutadrșțendus tadā śatrurujārditaḥ|

bhayodvegau śarīre ca raktavātasya vikriyā $\|$

mitrabandhujanaih kleśo hānir nairrtyabhāgatạ̣|

vātajvarajalädibhyo bhayam mūrchābhramārtayaḥ \|

sañgah pāpātmabhir dharmanāso vātārtiruddhatā |

sarvakāryakrtā cintāsaṃtoṣo rāhuyuk śaśi $\|$

ketunā yutadrșțaś ced anuṣnagur udāsakṛt |

pīdā ca mitrabandhūnāṃ raktavātasya vikriyā $\|$

mürchä jvarāmayah sarpajalabhịh kalaho 'sakrt |

syān nairrtīidiśo hānị̣ ketunā sahitạ̣ śaśī ||

2 śrī] strī K T M 9 pada] pade B N G \| vastutah]] vastunaḥ N G K T M 12 uttama] uma N \| śayanāsana] śayanāśana K T || bhojanam] bhojanaḥ B N G K T 13 prāptiḥ] prāmị̣ N 14 sugandha] sugandhan K T M $\|$ vastrādi] vastrāṇi B N G 15 dṛsțendur] dṛșțeṃdus B N G 15-21 dṛștendur ... yuta] om. B N 15 udvegaṃ] tadvegam G 17 kānaāt pañgor] kāṇāṃtyagor $\mathrm{G} \|$ bhavet] vadet $\mathrm{G} \quad 19$ durbuddher vyasanāgamaḥ] durbuddhe 'rthasamāgamah G 20 yuktah]] yukto K T M 22 bhayo-] bhaye B G; bhagre N \|v vikriyā] vikrayā B N G 23 nairṛtya] nairṛti B N G a.c.; nairṛta G p.c. 24 bhramārtayah] tramārtavaḥ B N G $\quad 25^{-29}$ sangah ... jvarāmayaḥ] om. K $\quad 25$ vātā] vāṃtā $G \quad 26$ saṃtoṣo] saṃtovo N 27 anuṣna $]$ anuṣka B N G 28-29 pị̣ā ... 'sakṛt] om. B N 30 syān] sān N G 
If the moon is joined to or aspected by Jupiter, it bestows gain of wealth, happiness, clothes, children, and the true delights of splendour. There is attainment of brilliant learning from the eastern quarter, and moreover [the native] enjoys great profit from the northern quarter. There is gain of vehicles; [the native] will enjoy and be greatly devoted to the Lord; [there is] honour and renown in the world and gain of gold from company with the great.

And when the moon is joined to or aspected by Venus, there is gain of pearls, ornaments, jewellery and so on from trade in white articles. [The native] is devoted to the feet of the Lord of the world; there is constant gain from articles derived from water; he derives happiness from associating with women; there is the birth of a daughter [or] gain of a woman. There will be happiness from the southeastern quarter, gain and increase of merit; from singing [he earns] enjoyment of the finest clothes and so on, beds and seats. He will attain the highest goal; playful, speaking together, ${ }^{50}$ the excellent man obtains perfumes, divine clothes and so on.

Joined to or aspected by Saturn, the moon produces agitation and fear, sorrow by dangers from princes and enemies, or loss from the western quarter. There will be little gain from the one-eyed or lame, destruction of wealth, and fear. In the body, there is skin disease from a corruption of the blood and low company; there is quarrel in the household, the appearance of vice from weak-mindedness, gauntness and withering of the limbs, if the moon is joined to Saturn.

Should the moon be joined to or aspected by Rāhu, then [the native] is plagued by enemies and illness; there is fear and agitation and, in the body, corruption of blood and [the humour of] wind. There is distress from friends and kinsmen; loss from the southwestern quarter; danger from [the humour of] wind, fever, water and so on; stupor, confusion, and pain. There is association with the evil-minded, loss of merit, crippling pain from [the humour of] wind, anxiety on account of every undertaking, and discontent, [if] the moon is joined by Rāhu.

If the moon is joined to or aspected by Ketu, it causes apathy; there is affliction to friends and kinsmen and corruption of blood and [the humour of] wind. There will be stupor, fever illness, danger from snakes and water, frequent quarrels, and loss from the southwestern quarter, [if] the moon is joined to Ketu. 
iti candraphalam \|

atha bhaumaphalaṃ varṣatantre |

bhaume 'bdape balini kīrtijayārināśaḥ senāpatitvarananāyakatāpratișțā| lābhah kulocitadhanasya namasyatāpi

lokeșu mitrasutavittakalatrasaukhyam \| madhye 'bdape 'vanisute rudhirasrutiś ca kopo 'dhiko jhakațaśastrahatikṣatāni| svāmitvam ātmaguṇato balagauravam ca madhyam sukham nikhilam uktaphalam vicintyam \|

hine 'bdape 'srji bhayam riputaskarāder lokāpavādabhayam ātmadhiyā vināśaḥ| kāryasya vișvag atirogabhayam videśayānaṃ kșayo 'panayato gurudrștyabhāve \|

kāryasya viṣvak sarvataḥ kāryasya nāśah | gurudṛștyabhāve sarvaṃ phalam syāt | taddṛ̣̦țisattve phalaṃ sarvaṃ śubhodarkaṃ syād iti | tejaḥsiṃhạ̣ |

vīryānvite 'vanisute 'vanipād ripor vā senāpateḥ sadhanatā janasevyatā ca| madhye tu madhyam abale tu videśayānam cauryāstrarugjvalanabhītyapakīrtighātāh ||

tājikasāre 'pi |

vīryānvite kṣitisute nrpater dhanāptih senāpate ripugaṇād vijayo raṇāc ca| sevā dhanaṃ bhavati mārgavaśāc ca saukhyam strīsangataś ca vividham sukham atra vindyāt ||

3 jayāri] jayori M 5 namasyatāpi] namasyatopi G; namasyatoṣi T $\quad 7$ srutiś] śrutiś $\mathrm{K} T$ 8 jhakața] bhakața M 9 ātma] āpta $\mathrm{G} \|$ guṇato] gaṇato K T M 13 vișvag] chik T 15 vișvak] chik KT 16 śubhodarkam] śubho G; śubhodayam K T M 19 madhye] madhyan K T M || madhyam] madhyeṃm N 22 vīryānvite] vīryānvito B N || dhanāptiḥ] dhanāptiṃ K T M

3-14 bhaume ... abhāve] VT 1.22-24 $\quad$ 17-20 vīryā- ... ghātāḥ] DA $15.5 \quad 22-496.8$ vīryā- ... vinașțe] TS 110-112 
This concludes the results of the moon.

\subsubsection{Mars as Ruler of the Year}

Next, the results of Mars [are described] in Varșatantra [1.22-24]:

If Mars as ruler of the year is strong, there is renown, victory, destruction of enemies, the eminence of commanding an army or leading it in battle, gain of wealth befitting one's family community, respect in society, and happiness from friends, children, wealth and wife. If Mars as ruler of the year is middling [in strength], there is flowing of blood, great anger, quarrels, blows from weapons, and wounds; authority by one's own merits and dignity from strength: happiness [and] all results described should be considered middling. If Mars as ruler of the year is poor [in strength], there is danger from enemies, robbers and so on, fear of censure from the world, failure of undertakings all round through [faults in] one's own thinking, danger of severe illness, travel abroad and loss from misconduct, in the absence of an aspect from Jupiter.

Failure of undertakings all round, [that is], of every undertaking. All [these] results will take place in the absence of an aspect from Jupiter; that is, when such an aspect is present, all [these] results will end well. [And] Tejạ̣siṃha [says in Daivajñālaṃkrti 15.5]:

If Mars is endowed with strength, [the native] becomes rich through the king, the enemy, or the commander of the army, and respected by the people; if [the strength is] middling, [the results are] middling; if [Mars] is weak, there is travel abroad, theft, [blows from] weapons, illness, fire, fear, infamy, and injury.

And in Tājikasāra [110-112 it is said]:

If Mars is endowed with strength, there is gain of wealth from the king, from the commander of the army, [or] from the enemy host, and victory in battle; there is service [performed for the native], wealth, and happiness on account of journeys, and he will find manifold pleasures from the company of women. If Mars is middling [in strength], there 
madhye kuje bhavati lohabhayam vivādam kuryāt krśatvam akhilāngam analparogam | vairodayaṃ nrpajaneșu dhanakșayaṃ ca caurād bhayam svajanato hy athavā narāṇām || caurāstrarugjvalanabhītyapakìrtilābhah

pittodayam bhavati pādamukhākșideśe | duștāa bhayam nijajanād dhanadhānyanāsah strīputramitrakalaham kșitije vinaște \|

viśeșaphalaṃ hāyanasundare |

varșapo yadi māheyo varșeṇa yutadrg yadi |

pittaraktaprakopo 'nyadāradurvyasane ratah $\|$ durnaye nirato mitrabāndhavair vigraho 'dhikah | taskarāgnibhayam dhatte yadi bhaumo 'sti varșapah \| ravina à yutadrșto 'tha vakro nrpakulād dhanam | satsanmānam avāpnoti kuryāt sāhasam uttamam || raṇe jayaḥ prāgdiśātah sukhalābho jvaras tanau| paścimasyām aläbho 'lpabhayam vittabhayaṃ kvacit \| candrena yutadrștaś ced bhaumo nānārthaläbhadaḥ| suhrdah sukham utsāham āpnoti maṇimauktikān \| putrabhrātrādivrddhị syāt sukham yuvatisaṃamāt | vastrābharanabhojyānām lābho vāyavyadigbhavah $\|$ cāndriṇa à dharanijo yutadrșto vairivargaparitāpam upaiti | rājavahninrpabhìr dhanahānị̣ pịdanam paśugaṇasya nitāntam \| raktapittaprakopah syāc cintā dhanadadigbhavā | bhaumena yutadrștaś ced budho 'śubhaphalapradah \| bhaumo guruyutadrștas tīrthaprāptih svadevagurubhaktah | punyamatih śubhasaṃgatim āsādya śubhārthasaṃcayam kurute \| vikhyātah sarvajane kulamadhye supratișthito bhavati | iśānadiśo läbhah svalpabhayam kim api sukham asau dhatte \| bhauma hitayutadrștah śatrukrodhād bhayam vapurduhkham | sopadravatā hānir gamanam durvyasanam agnidigbhìtih ||

2 krśsatvam] kṛāmatv N 7 dhana] dhara $\mathrm{K} \quad 9$ viśeșaphalaṃ] viśeșaṃ B N 12 durnaye] duryyane K T || nirato] tirato G 18 bhaumo] āro K T M 19 āpnoti] āmoti N 20 bhrātrādi] bhrātṛ K T M $\|$ vṛddhiḥ] pravṛddhis M 22 vairivarga] vai vivarga $G \quad 23$ dhana] hana T 26 yuta] yuto K T M \| svadeva] sadeva K T M 28 pratișțito] pratișțho K T 29 asau] adhau G 31-498.2 durvyasanam ... hānir] om. B N

10-498.12 varṣapo ... yutah] HS 151-167 
is danger from iron; it makes quarrels for men, gauntness in the whole body and no little illness, the arising of enmity with princes, loss of wealth, danger from robbers or from one's own people. He meets with robbers, [blows from] weapons, illness, fire, fear, and infamy; there is disturbance from [the humour of] bile in the regions of the feet, mouth, and eyes; danger from the wicked, loss of wealth and crops from one's own people, and quarrels with wife, children, and friends, if Mars is corrupt.

Detailed results [are described] in Hāyanasundara [151-167]:

If Mars is ruler of the year, [or] if it is joined to or aspecting the year, there is agitation of bile and blood. [The native] is given to evil passions with others' wives, devoted to misconduct; there is much conflict with friends and kinsmen. It gives danger from robbers and fire, if Mars is ruler of the year.

If Mars is joined to or aspected by the sun, [the native] obtains wealth from a princely family and the esteem of good men; he commits great violence; there is victory in battle, gain of happiness from the eastern quarter, and fever in the body. There is loss in the west, a little danger, and sometimes danger [of losing] money.

If joined to or aspected by the moon, Mars gives gain of manifold goods: [the native] wins friends, happiness, fortitude, pearls and jewels. There will be increase of children, brothers and so on, happiness from the company of women, and gain of clothes, ornaments and food from the northwestern quarter.

[If] Mars is joined to or aspected by Mercury, [the native] suffers torment from enemies; there is danger from the king, fire and princes, loss of wealth, and intense suffering for his cattle. There will be agitation of blood and bile and anxiety from the northern quarter: if joined to or aspected by Mars, Mercury gives evil results.

[If] Mars is joined to or aspected by Jupiter, [the native] visits a sacred place, is devoted to his own deity and preceptor, of pious inclination: he seeks out good company and accumulates a wealth of good [deeds]. Well-known to everyone, he is celebrated in his own family community. There is gain from the northeastern quarter: that [planet] gives a little danger, but more happiness.

[If] Mars is joined to or aspected by Venus, there is danger from the wrath of his enemies, suffering of the body, sudden calamity, loss, going away, vice, and danger from the southeast. 
śaniyutadrșțe bhaume duḥkham udāso vicintitā dauhsthyam |

hānir durvyasanatvam durbuddhir nicasaṃgamatặ $\|$

udvegaḥ syāt paścimāsāâbhayo hāniḥ sitetarāt |

manujād vā yaśohānir bhaumaś cec chanidrgyutah $\|$

rāhuṇā yutadrșțaś cel lohitāñgo bhayaṃkaraḥ|

caurāgniṇ̛rpaśatrūnām bhìtidah sukhahānikrt \|

śarīre vātakaștam syād bhayam nairrtyadigbhavam |

tathodvego hānir arthe nīcasañgād adharmakrt ||

syāt ketuyutadrștaś cet kujo vidyudbhayaṃkarah |

syān meghagarjanād bhìtiś codagagniripor api $\|$

śarìre 'pi rujātañkau kleśaś caurād aher bhayam |

śokacintāparo bhūyād bhaumah ketudṛśāyutah \|

iti bhaumaphalam $\|$

atha budhaphalam varṣatantre |

saumye 'bdape balavati prativädalekhya-

sacchāstrasadryavahrtau vijayo 'rthalābhah |

jñānaṃ kalāganitavaidyabhavaṃ gurutvaṃ

rājāśrayeña nrpatā nrpamantritā vā $\|$

adbādhipe śaśisute khalu madhyavirye

syān madhyamamn nikhilam etad athädhvayānam |

vānijyavartanam athātmajamitrasaukhyam

saumyetthaśālavaśato 'parathā na kimcit ||

nikhilaṃ padyoktam vānijiyena vartanam jīvanam | atra budhasaumyetthaśāle prāguktaṃ śubhaphalam avikalaṃ syād anyathā na | atra mārga-

5 bhayaṃ] bhavam N $\quad$ 7-10 śarīre ... api] om. B N G a.c. 8 tathodvego] tathābde go G 11 śarīre 'pi] śarīropa B N G a.c.; śarīrepa G p.c. \|| kleśaś] leśaś N 12 bhūyād] bhūpad T; bhūpād M || dŕ̛āā] vṛśā N || yutaḥ] punạ̣ B N G 21 vartanam] vartmanam T 23 nikhilaṃ] prāk add. K T M || budha] budhe K T M 24 prāguktaṃ] prāyuktaṃ K T

15-22 saumye ... kimcit] VT 1.25-26 
If Mars is joined to or aspected by Saturn, there is suffering, apathy, anxiety, uneasiness, loss, addiction to vice and weak-mindedness due to low company. There will be agitation, danger from the western quarter, loss due to a black man, or loss of reputation, if Mars is aspected by or joined to Saturn.

If Mars is joined to or aspected by Rāhu, it causes fear, gives dangers from robbers, fire, princes and enemies, and puts an end to happiness. There will be pain in the body from [the humour of] wind and danger from the southwestern quarter; likewise agitation and loss of wealth, [and the native] commits unlawful acts due to low company.

Should Mars be joined to or aspected by Ketu, it makes danger from lightning; there will be fear of thunder, of northern fire ${ }^{51}$ and enemies. There is illness and ache in the body, affliction from robbers and danger from snakes; [the native] will be given to grief and anxiety, if Mars is aspected by or joined to Ketu.

This concludes the results of Mars.

\subsubsection{Mercury as Ruler of the Year}

Next, the results of Mercury [are described] in Varșatantra [1.25-26]:

If Mercury as ruler of the year is strong, there is victory and gain of wealth by debate, writings, true teachings and honest dealings; knowledge; office as a teacher of arts, mathematics or medicine by royal patronage; and the status of a prince or of a prince's counsellor. Indeed, if Mercury as ruler of the year is of middling strength, all this will be middling; then there is going on a journey, occupation with trade, and happiness from children and friends, on account of a benefic itthaśäla; otherwise, nothing.

The 'all' mentioned in the verse is the occupation, [that is], livelihood, by means of trade. ${ }^{2}$ Here, if Mercury has a benefic itthaśâla, the good results described above will be unimpaired; otherwise, not. Concerning this, from Samarasimhha's statement [in the Tãjikaśāstra, beginning] 'On the road,

$5^{1}$ Or, possibly, 'upwards-moving fire'. Meaning uncertain. An independent witness of the Hāyanasundara reads 'robbers and fire', but this unmetrical reading is more likely to be a copyist's emendation of a difficult passage than the original version.

$5^{2}$ It is not clear why Balabhadra should feel the need for this forced interpretation. 'All this' more naturally refers to the results previously described: victory in debates, etc. 
gatā budhabhāvān iti samarasiṃhavākyena pūrṇabale budhe varșeśe adhvayānam api vācyam |

saumye 'bdape 'dhamabale balabuddhihānir

dharmakșayah paribhavo nijavākyadoșāt |

nikșepato vipad atīva mrșaiva sākșyam

hānih paravyavahṛteh sutavittamitre \|

tejaḥsiṃhah |

sevārthamānalikhanādiphalaṃ sutādi-

toșo budhe 'dhikabale vyavasāyalābhah |

madhye tu madhyam akhilam nijavākyadoșāt

sarvārthahānir adhame 'nrtasākșitā ca \|

tājikasāre 'pi

varșādhipe śaśisute sabale 'tisaukhyam

sevā dhanam likhanatah pațhanādiläbhaḥ|

strimitrasaukhyam atulam sutataś ca nūnam

vānijyato dhanasamāgamanaṃ vilāsaḥ $\|$

madhyaś ca somatanayo nijavākyadoșāt

sarvārthahānim aśubham prakaroty anartham |

strimitraputrakalaham sukham atra cālpam

vairodayam nrpajanāt svajanāc ca tadvat ||

naște budhe nrpabhayo 'nrtasākșitā ca

kleśodayah svajanato 'rthalayo vivādaḥ|

caurād bhayam hrdi galāmayakrt svanetra-

pìdā bhaven nikhilamadhyamakam ca dagdhe \|

viśeșaphalaṃ hāyanasundare |

\footnotetext{
1 bhāvān] scripsi; bhavān B N G; mavān K T M || iti] vākye add. K T M 3 'dhama] 'ma T 8 sevā] senā B N G a.c. \| likhanādi] khalinodi N 9 'dhika] kika G 20 svajanāc ca] svajanīcca G 21 sākṣitā] sākșitam B N 24 bhaven nikhila] bhavebhikihila N

3-6 saumye ... mitre] VT 1.27 8-11 sevā ... ca] DA 15.6 13-24 varṣā- ... dagdhe] TS 113-115

1 bhāvān] While the emendation is necessarily conjectural due to the lack of of context, some emendation is required by the metre, assuming this to be $\bar{a} r y \bar{a}$ as in virtually all quotations attributed to Samarasimpha.
} 
those of Mercury's nature, ${ }^{53}$ going on a journey should be predicted even when Mercury as ruler of the year has full strength. [Continuing from Varșatantra 1.27:]

If Mercury as ruler of the year is of poor strength, there is loss of strength and intellect, loss of merit, humiliation through the fault of one's own words, grave misfortune due to a pledge, false testimony, loss with regard to children, wealth and friends from dealings with others.

[And] Tejaḥsiṃha [says in Daivajñālaṃkrti 15.6]:

If Mercury has great strength, there are results like service, wealth, honour, and writing; contentment with children and so on; and gain through business. If [its strength] is middling, all is middling; if it is poor, there is loss in all things through the fault of one's own words, and false testimony.

[And] in Tājikasāra [113-115 it is said]:

If Mercury as ruler of the year is strong, there is great happiness, service, wealth from writing, gain from reading and so on, incomparable happiness from women and friends, and indeed from children, acquisition of wealth from trade, and delights. Middling [in strength], Mercury brings about loss in all things through the fault of one's own words; misfortune and reversals; quarrels with women, friends, and children, and little happiness; the arising of enmity with princes, and likewise with one's own people. If Mercury is corrupt, there is danger from princes, false testimony, onset of suffering, loss of wealth through one's own people, disputes, and danger from robbers; it makes illness of the heart and throat; there will be affliction to his eyes; and if [Mercury] is burnt, all [results are] middling. ${ }^{54}$

Detailed results [are described] in Hāyanasundara [168-188]:

53 Both the fragmentary Sanskrit phrase itself and its meaning are uncertain.

54 Although this last interpretation seems astrologically unlikely, and the Sanskrit is syntactically awkward, all text witnesses agree. 
varșalagnapatiś cāndrir yutadrșțo 'tha satphalam | datte divyānganābhogaṃ dhișaṇām atisundarìm \| svadharmaniratah putramitravargena saṃyutah | suhṛāạn sutakanyādivṛddhiḥ sānandamoditạ̣ \| kadācit syād vapuhpị̣̂ā lābhaḥ syād uttarādiśạ̣| sarvaśāstrapravinaś ca varșapaḥ syād budho yadi || rohininandanaḥ sūryayutadrșțo yadā bhavet $\mid$ vapuṣi jvarabādhā syāt kiṃcic chatrubhayaṃ bhavet \| tathā rājakulāt prītih strīputrasvajanotsavah | tīrthaprāptis tathā lābhaḥ pūrvāsáātah phalodgamạ̣ \| suvarnāsóvapravālādipaśuvargādisaṃcayạ̣| akasmād api labdhịh syād budhayukto ravir yadā $\|$ syāc candrayutadrștas tu saumyo 'saumyakarah smrtah | kāsadadrukrtāạn pị̂ā̄m karoti gajasādhvasam \| pāmā kharjūr añgabhañgah paśūnāṃ vadhapịdanam | śatror bhayạn vināśs vā cintā vāyavyadigbhavā| suhṛdo 'pi virodhaḥ syān mahișādiranāa d bhayam || syād bhaumayutadrștaś cec candrajo dìrgharogakrt | kule vā duḥkulam kopah sthānabhraṃśam avāpnuyāt \| $\bar{a}$ dhir vā dasyubhịh kleśạ sambhramah parasamgamāt | śiro'rtih svarnakāārād vā hāniryāmyadiśo bhavet || gurunā yutadṛk saumyo bhayavyādhinikrntanaḥ| śatrunāśo narendrādisanmāno mahanīyatā $\|$ satyavaktā punyatīrthe lābho dharmavrate dṛ̣hah | iśānadigbhavam saukhyaṃ prītiläbhaṃ prayacchati $\|$ bhārgaveña yuto drșțojño vijñānakalāpakrt | bahustrīsamgamād rāmāratiprītipramodadah $\|$ strīsamgamāt sukhaprāptir lābhah śvetakrayānakāat | svadevagurubhaktaḥ syād vadānyo nāțakapriyaḥ \| sukham māngalyam utsāham kurute mitrasaṃamam |

5 uttarā] uttaro B N G 10 prāptis] prāmis N 11 suvarṇāśva] suvarṇaśva G 15 kharjūr angga] kharjjūrāṃga $\mathrm{B} N$; khārjūragaṃ $\mathrm{M} \quad 17$ suhṛdo] suhṛdbhyo T 19 duḥkulaṃ] duhkalam K; duṣkalaṃ M || kopah]] kotha K T M 22 yuta] yukta K T \| saumyo] saumye B N G 23 sanmāno] sanmānā B N G 26 jño] go B N G 28 sukhaprāptir] sukhāt prāptiḥr B; sukhātmāptiḥ̂ N G \|| śveta] sveta B N G 29 syād] svad N G \| priyaḥ] miyaḥ N

1-504.12 varșa ... karaḥ] HS 168-188 
Mercury as ruler of the horoscope of the year, [or] joined to or aspected by [the ruler of the year], gives good results: enjoyment of divine women and the most beautiful discernment. [The native] is devoted to his own duties, accompanied by his circle of children and friends; there is increase of friends, sons and daughters and so on, [and he is] happy and delighted. Occasionally there will be pain in the body; there will be gain from the northern quarter; and [the native] is accomplished in all sciences if Mercury is ruler of the year.

When Mercury should be joined to or aspected by the sun, the body will be afflicted by fever, and there will be some danger from enemies; [but] there is also favour from a princely family, celebrations with wife, children and one's own people, visiting a sacred place, gain from the eastern quarter and the arising of [good] results. There is accumulation of gold, horses, coral, various cattle, and so on, and there will be sudden gain, when Mercury is joined to the sun.

But should Mercury be joined to or aspected by the moon, it is known to give evil results: it makes afflictions caused by cough and skin disease, and peril from elephants. There is scabies, itching, broken limbs, the suffering of cattle being killed, danger from or destruction by enemies, anxiety from the northwestern quarter, opposition from friends, and danger from buffaloes and battle.

If Mercury should be joined to or aspected by Mars, it makes long illnesses, or there is a low connection ${ }^{55}$ in the family, and anger; [the native] will lose his place. There will be anxiety or suffering from robbers, confusion by mixing with strangers, headache, loss through a goldsmith or from the southern quarter.

Joined to or aspected by Jupiter, Mercury puts an end to fear and illness: there is destruction of enemies, honours from princes and so on, and a position of respect. [The native] speaks the truth; there is gain in a sacred place; he is firm in his religious vows. [Mercury] gives happiness from the northteastern quarter and gain of affection.

Joined to or aspected by Venus, Mercury ties a garland of learning; it gives delight in the pleasures and affection of ladies by the company of many women; there is attainment of happiness from the company of women and gain from trade in white articles. [The native] will be devoted to his own deity and preceptor, generous, fond of theatre. [Mercury] brings happiness, auspiciousness, joy and the company of 
rājacihnapadaprāptih śatrunāsam karoti vā |

syād āgneyadiśạ̣ saukhyaṃ budhạ śukrena dṛstayuk \|

saurina āyutadrștas tu dharmabhraṃśakaro budhah |

sambhogasamaye kārśyam śitalatvam prajāyate ||

pramehädivikāro vā nīcasañgād dhanavyayaḥ|

klïbe prïtir gṛhe kleśo veśyādāsīṣu vā ratih ||

budhas tamodrștayutah sāhasam kurute 'dhikam |

sarvakāryakrtotsāhah kiṃcic cittabhramo 'pi ca \|

syān nairrtidiśo lābho vātodbhütarujārditaḥ |

kim ca nìcajanāt saukhyam labhate manujaḥ sadā ||

rohinītanayah ketuyutadrșto yadā bhavet |

śokahānikaro nīcasamgamād asukhaṃkarah \|

iti budhaphalam \|

atha guruphalam varșatantre |

jōve 'bdape balayute parivārasaukhyam

dharmo guṇagrahilatā dhanakīrtiputrāḥ|

viśvāsyatā jagati sanmativikramāptir

läbho nidher nrpatigauravam apy arighnam \|

guṇeșu śauryādișu āgrahavattā |

adbādhipe suragurau kila madhyavirye

syān madhyamam phalam idạ̣ nrpasamgamam ca|

vijñānaśāstraparatāpy aśubhesarāphe

dāridryam arthavilayaś ca kalatrapị̂ā $\|$

1 prāptiḥ] prātiḥ N $\quad 3$ karo] kare N $\quad 5$ vā] ca G 6 klībe] lībe N 10 kiṃ ca] kiṃcin K T; kiñcin M 16 grahilatā] grahitṛtā M 17 sanmati] sa K 19 guṇeșu] gusoṣu N G a.c.; guṇoșu G p.c. || ādiṣu] ādi B N G a.c. || āgrahavattā] āgrahaṃ vā M 20 vīrye] vīrdhye $\mathrm{G}$ 21 saṃgamaṃ] sangamaś K T M 22 paratāpy aśubhe] paratā na śubhe K T M

15-18 jīve ... arighnam] VT 1.28 20-506.4 adbādhipe ... ca] VT 1.29-30 
friends; there is attainment of rank [marked by] royal insignia, or it causes the destruction of enemies. There will be happiness from the southeastern quarter, [if] Mercury is aspected by or joined to Venus.

But joined to or aspected by Saturn, Mercury makes [the native] stray from piety. At the time of lovemaking, weakness and coldness is engendered [in the sexual organ], or there are urinary and other disorders; there is loss of wealth by low company, affection for an effeminate, ${ }^{56}$ domestic unhappiness, or intercourse with prostitutes and servant girls.

Aspected by or joined to Rāhu, Mercury does great violence; there is much exertion in all affairs, and some mental disturbance. There will be gain from the southwestern quarter; the man is plagued by illness produced by [the humour of] wind and always derives happiness from low people.

When Mercury should be joined to or aspected by Ketu, it makes sorrow and loss, and brings unhappiness from low company.

This concludes the results of Mercury.

\subsubsection{Jupiter as Ruler of the Year}

Next, the results of Jupiter [are described] in Varșatantra [1.28]:

If Jupiter as ruler of the year is endowed with strength, there is happiness from retinue, piety, virtuous inclination, wealth, renown, children, the confidence of the people, attainment of good opinion and valour, gain of treasure, and dignity from the king, destroying one's enemies.

[Virtuous inclination means] having a proclivity for virtues such as courage. [Continuing from Varșatantra 1.29-30:]

Indeed, if Jupiter as ruler of the year is of middling strength, these results will be middling, and [likewise] the company of princes. There is devotion to learning and sciences; but, if there is an isaräpha with a malefic, poverty, dissolution of wealth, and suffering to one's wife. If

$5^{6} \quad K l i ̄ b a$, a synonym of napumsaka; cf. Chapter 4, note 89 . 
jīve 'bdape 'dhamabale nrpato 'rthasaukhya-

hānis tyajanti sutamitrajanāh sabhāryāh |

lokāpavādabhayam ākulatāpi kașta-

vrttis tanau kapharujo ripubhịh kaliś ca \|

tejahssiṃhah |

dharmārthakīrtidhanabuddhyarisampdhiloka-

viśvāsyatāsutasukhāni saviryajīve|

madhye ca madhyam idam eva phalam ca nindye

dharmārthahānyaśubhabandhuvirodhabādhā $\|$

tājikasāre 'pi |

devārcito balayutah pramadāvilāsam

kuryāt samitrasutato vividham ca saukhyam |

vittāgamo nrpatito vijayo ripūṇām

viśvāsyatā sakalalokajaneșu śaśvat ||

nākeśvarasya sacivaḥ khalu madhyaviryo

lokair virodham aśubham prakaroti bhūpāt |

vairodayam svajanataś ca parair vivādam

kuryāt krśatvam api caurabhayaṃ sadāsau \|

nindye gurau khalu bhaven nrpato 'rthanāso

dharmārthahānyasukhabandhwvirodhapị̄̂a |

pādākșigulphajațhare jaghaneșu nịṇām

vātärtikrt tv aribhayam tanusaṃkșayah syāt \|

viśeșaphalaṃ hāyanasundare |

varșapo yadi gurur yutadrșțo dīptikrd diśati dhānyadhanāptim |

rājamānyasutasaṃtatikartā kāñncanādimaṇimauktikalābhah $\|$

1 saukhya] saukhyam M 3 kaștạ] kașțam K T; kașțam M $\quad 6$ loka] loke B $\quad 7$ viśvāsyatā] viśvāsatā B N G 8 nindye] nindyaṃ K T M 11 devārcito] devārcako M 13 vijayo] scripsi; vijayaṃ B N G; vilayaṃ K T M 14 viśvāsyatā] viśvāsatā B N G $\quad 15$ vīryo] vīrye B N 16 lokair] loka K; loke T M 17 vairodayaṃ] vairodayaḥ M 19 nụpato 'rthanāśo] nụpater vināśo B N $\quad 21$ gulpha] gulma $G \|$ jaghaneșu] janagheșu B N a.c.; janadyeșu N p.c. $\quad 22$ -kṛt tv] kratv G || saṃkșayaḥ] saṃkșayaṃ G 24 dṛșțo] dṛșțe N 25 rāja] rājya B N

6-9 dharmārtha ... bādhā] DA 15.7 11-22 devā ... syāt] TS 116-118 24-510.11 varṣapo ... yadi] HS $189-207$ 
Jupiter as ruler of the year is of poor strength, there is loss of wealth and happiness through princes; children and friends leave [the native], along with his wife; there is danger of slander by people [in general], distress, evil occupation, illnesses of phlegm in the body, danger from enemies, and quarrels.

[And] Tejạ̣siṃha [says in Daivajñālaṃkrti 15.7]:

If Jupiter is strong, there is piety, goods, renown, wealth, comprehension, reconciliation with enemies, the confidence of the people, children, and happiness. If [the strength] is middling, these same results are middling; if poor, there is the affliction of loss of merit and goods, misfortune, and conflict with kinsmen.

[And] in Täjikasāra [116-118 it is said]:

Endowed with strength, Jupiter will make delights with women and manifold happiness with friends and children; there is acquisition of wealth from princes, victory over enemies, and the constant confidence of all the people. Indeed, Jupiter being of middling strength brings about conflict with people [in general] and evils from the king, the arising of enmity with one's own people and quarrels with others; it will always make gauntness and danger from robbers. Indeed, if Jupiter is poor [in strength], there will be loss of wealth through princes ${ }^{57}$ and the affliction of loss of merit and goods, unhappiness, and conflict with kinsmen; it makes men suffer from [the humour of] wind in the feet, eyes, ankles, stomach and hinder parts; there will be danger from enemies and a wasting away of the body.

Detailed results [are described] in Hāyanasundara [189-207]:

If Jupiter is ruler of the year [or] illuminates [the ruler of the year, being] joined to or aspected [by it],,$^{58}$ it indicates gain of crops and wealth; it makes him honoured by the king and provides him with children; there is gain of of gold and other [precious metals], gems and

57 Text witnesses B N read 'destruction of/from the king'.

$5^{8}$ This terse phrasing probably refers to Jupiter aspecting or conjoining another planet within its orb of light; cf. section 3.1. 
punyatìrthādigamanaṃ lābhas tūttaradigbhavaḥ|

vastraratnavibhūṣādilabdhir uttamamānușāt \|

ravinā yutadrștaś cej jivvah śatrunikrntanah |

khyāto rājakule tejovrddhir bādhā jvarāditah \|

śiro'vartir vātapịdà kiṃcid rājabhayam bhavet |

svalpah pūrvadiśo lābhaḥ sahajāt kalahapriyah \|

vidhuyutadrșto jivvo lalanäbhogam karoti sukhavrddhim |

śubhaśayanāsanabhojanasutasuhṛdām prāptim adhipasanmānam ||

sitavastutas tu läbhah striyo 'pi varabhogasaukhyam adhikataram |

vāyaryadiśo lābhah kāsādivyasanam api kvacit \|

bhaumena yutadrștaś ced dhanasaukhyapadapradaḥ|

rane jayo raktavasturyāpārāl labdhir uttamā $\|$

yaśo nīrogatā saukhyam syād dakșinadiśas tathā |

nrpād bhayam jvaram kiṃcid bhaumadrșțe yute gurau \|

budhena yutadrștaś ced ratisaukhyapadapradaḥ|

vittaläbhạ sukhe duḥkhe sāmyam vā śatrumitrayoḥ \|

läbhavyayasamo devagurupādaratậ sadā|

labdhir uttaratah kiṃcic chiro'rtir buddhivaibhavam ||

sitayutadrșțe jōve dhanahānị̣ kleśatā ripoḥ kācit |

buddhibhramśso yuvatīiviyojito hānir api ca rudradiśạ̣ \|

śaniyutadṛsțe dhișaṇe mlecchabhayam sthānahānih syāt |

dyūtakrị̈amadhupānakelirataś cādhamaị sañgaḥ \|

visphoțakādivikrtir vātādhikyam jalād bhayam karabhāt |

hānir manujāt krṣnāat krșāṇakād api ca mahișabhayam \|

cintā vārunadigbhūtā dhanahānir api dhruvam |

2 uttama] uttara B N 3 nikṛntanaḥ] nikraṃtanaḥ G 4 āditaḥ] ārdditaḥ BN 5 śiro’vartir] śirovārtir B N K; śirovārti T; śirortir vā M \| rāja] rājya G 6 sahajāt] sahasāt B N K; sāhasāt G T || kalaha] kalahaḥ T 7 vidhu] guru G \| jīvo] caṃdro G \| vṛddhim] vṛddhih G 8 -āsana] -āśana K M $\|$ prāptim] prāptir G 9 vara] vața $\mathrm{G} \mathrm{\|} \mathrm{bhoga]} \mathrm{bhogya} \mathrm{B} \mathrm{N} 10$ kvacit] kiṃcit G KTM 13 dakșiṇa] dakșiṇa add. B 15 rati] ati K T M 16 sukhe] scripsi; sukham B N G K T M \|| duhkhe] scripsi; duḥkham B N G K T M 17 vyaya] vyayau K T M \| samo] samau B N K T M 19 kācit] kvacit B N 21 mleccha] mlekșa K \| sthāna] māna add. KT M 22 krị̄a] scripsi; krị̄ā B N G K T M \| pāna] scripsi; pāne B N G K T M \| rataś] rātaś K T; ratiś M 23 vātā] vā N 24 kṛ̣āṇakād] krayāṇakād B N K T 25 dhana] dhanaṃ B N

22 dyūta ... pāna] The emendations, required by the metre, do not affect the meaning. 
pearls. There are journeys to sacred places and so on, gain from the northern quarter, and acquisition of clothes, jewels, ornaments and so on from an exalted person.

If Jupiter is joined to or aspected by the sun, [the native] strikes down his enemies and is famed in a princely family; there is increase of vigour [but] affliction from fever and so on, headache and suffering from [the humour of] wind; there will be some danger from the king, little gain from the eastern quarter; he is quarrelsome by nature.

Joined to or aspected by the moon, Jupiter brings enjoyment of women, increase of happiness, gain of good beds, seats, food, children and friends, and the respect of the king. There is gain from white articles, very great happiness from exquisite enjoyment of a woman, gain from the northwestern quarter but occasional suffering from cough and so on.

If joined to or aspected by Mars, [Jupiter] bestows wealth, happiness and rank; there is victory in battle and excellent gains from dealing in red articles. There will be renown, health, and happiness in the southern quarter, [but] some danger from the king and fever, if Jupiter is aspected by or joined to Mars.

If joined to or aspected by Mercury, [Jupiter] bestows [sexual] delight, ${ }^{59}$ happiness and rank; there is gain of wealth, equanimity in happiness and sorrow, or towards friends and enemies; [the native] is the same in gain and loss, constantly devoted to the feet of his deity and preceptor; there is gain from the northern quarter, some headache, and extraordinary intelligence.

If Jupiter is joined to or aspected by Venus, there is loss of wealth, some suffering from an enemy, and mental deterioration; [the native] is separated from a woman; and there is loss from the northeastern quarter.

If Jupiter is joined to or aspected by Saturn, there will be danger from foreigners and loss of position; ${ }^{60}$ [the native] is given to gambling, amusements, and drinking wine; there is low company, disorders such as boils, an excess of [the humour of] wind, danger from water [or] a camel, loss through a black man or a ploughman, ${ }^{61}$ and danger from buffaloes. There is anxiety from the western quarter, and certainly

59 Text witnesses K T M read 'great' (sc. happiness).

6o Text witnesses K T M add 'and honour'.

61 Text witnesses B N K T read '[a black] article of trade'. 
mahișāt karabhāt prāptị̣ kācic chaniyute gurau \| saimhikeyena yutadrg gurur bandhanakaștadah | bandhupịdā vapurvātapịditam jvarayakșmaṇā $\|$ suhrdviyogād udvego manastāpo mrter bhayam | kule śokaḥ padabhraṃśo jalasarpabhayam bhavet || syād āgneyadiśo bhītir bhaved asitamānușāt | hānir vā yutadrșțaś ced gurū rāhugraheña ca \| syāt ketuyutadrștaś cet surarājapurohitah | putrabhrātrādisambandhāt sthānabhraṃśam avāpnuyāt \| deśabhramaṇaśla h syāe cintā vai nīcasaṃamāt | aśubhaṃ kurute ketuyutadrșțo gurur yadi \|

iti guruphalaṃ \|

atha śukraphalaṃ varșatantre |

śukre 'bdape balini nīrujatā vilāsaḥ sadvastraratnamadhurāśanabhogatoṣāḥ |

kșemapratāpavijayā vanitāvilāso

hāsyaṃ nrpāśrayavaśena dhanam sukham ca \| abdādhipe bhrgusute khalu madhyavīrye syān madhyamam nikhilam etad athālpavrttị | guptam ca duhkham akhilam sunibaddhavrttih pāpārivīkșitayute vipado 'rthanāśą $\|$

alpavṛttir niyatavṛttị̣ sunibaddhā sarvato niṿ̛ttā vṛttiḥ |

śukre 'bdape 'dhamabale manaso 'titāpo lokopahāsavipado nijavrttināśạ |

\footnotetext{
1 mahișāt] mahișī B N G 2 gurur] guru B N 3 vapurvāta] ca yuvati B N K 4 viyogād] viyoga $\mathrm{G} \quad 5$ bhramsśo] bhraṃśe B N 6 bhaved] nīcād G $\quad 7$ ced] ca B N \| gurū] guru B N 10 cintā vai nīca] citte nīcasya $G \quad 15$ āśana] āsana K M $\quad 20$ vṛttiḥ] vṛ̣ddhị̣ G $\quad 22$ alpa ... vṛttiḥ̣ $]$ om. K T M

14-21 śukre ... nāśah] VT 1.31-32 23-512.2 śukre ... saukhyam] VT 1.33
} 
loss of wealth, [but] some gain from buffaloes and camels, if Jupiter is joined to Saturn.

Joined to or aspected by Rāhu, Jupiter gives the evils of imprisonment, affliction to ${ }^{62}$ kinsmen, and being afflicted by [the humour of] wind in the body ${ }^{63}$ through consumption with fever. There will be agitation due to separation from friends, mental suffering and fear of death, sorrow in the family, loss of position, and danger from water and snakes. There will be danger from the southeastern quarter, or there will be loss due to a black man, if Jupiter is joined to or aspected by the planet Rāhu.

If Jupiter is joined to or aspected by Ketu, [the native] will lose his place on account of his children, brothers, and so on. He will be inclined to roam the country and there is anxiety due to low company: if joined to or aspected by Ketu, Jupiter produces [such] evils.

This concludes the results of Jupiter.

\subsubsection{Venus as Ruler of the Year}

Next, the results of Venus [are described] in Varșatantra [1.31-32]:

If Venus as ruler of the year is strong, there is health, delight and the satisfaction of fine clothes, jewels, sweet foods, and pleasures; well-being, prowess and victory; delight from women; laughter, wealth and happiness on account of royal patronage. Indeed, if Venus as ruler of the year is of middling strength, all this will be middling, and there is little occupation, all secret suffering, occupation most hindered; if [Venus] is aspected by or joined to malefics or inimical [planets], misfortunes and loss of wealth.

'Little occupation' [means] restricted occupation; 'most hindered' [means] occupation obstructed on every side. [Continuing from Varșatantra 1.33:]

If Venus as ruler of the year is of poor strength, there is great mental torment, misfortunes [making the native] the laughing-stock of the world,

62 Or, possibly, from.

63 Text witnesses B N K read 'afflicted by a young woman'. 
dveșah kalatrasutamitrajaneșu kaștād

annāśanaṃ ca viphalakriyatā na saukhyam \|

tejaḥsiṃhena |

śukre kalatravaravastravarānnapāna-

nīrogatākhilavilāsasukham savirye |

madhye ca madhyam akhilam khalu guptaduhkham

nindye 'khilāsukhapadam janahāsyatā ca \|

tājikasāre 'pi |

daityeśvarasya sacivah paripūrnavīryo

dadyād varānnavanitāsuvilāsahāsyam |

ārogyatākhilavilāsasukham ca lābham kṣemapratāpavijayam sumatim ca dadyāt || madhyo nrpāt svajanatas tv arito virodham śleșmārtikrc ca sutadārabhayam ca kașțam | kāryārthahānim api moharujodayam ca kuryān na saukhyam iha svīyadaśāpraveśe \| nindye 'site 'khilajanāt kalaho nitāntam syād vairito nrpajanād asukhatvam atra | saukhyārthahānir atiśokabhayam vivādo dagdhe svapākavișaye matisaṃkșayam ca \|

viśeșaphalaṃ hāyanasundare 'pi |

varșādhipo yadi bhrgos tanayo 'tha drșțo

yukto 'śvavāhanavibhūṣanatādilābhaḥ|

kanyāprasūtir atha dharmapadārthasārtha-

buddhiprakāśakuśalatvam upaitijantuh \|

\footnotetext{
1 janeșu] jane B a.c. N 2 ca] om. B N || kriyatā] vikriyatā B 3 tejaḥsiṃhena] tejaḥsiṃhah G K T M 6 ca] sva B N G 18 asukhatvam atra] asukham camatra B N; asukhañ ca tatra KTM 19 vivādo] vivāde N 2o dagdhe] ragdhe N 21 'pi] om. GKTM 23 yukto] yuto B N; yuktaś K T M || 'śva] ca K T M 25 kuśalatvam] latvam N

4-7 śukre ... ca] DA 15.8 9-20 daitye- ... ca] TS 119-121 22-516.6 varșādhipo ... phalam] HS 208-223
}

16 svìya] The unmetrical reading is supported by all witnesses. 
the loss of one's own occupation, enmity with one's wife, children, and friends, difficulty finding food to eat, useless endeavours and no happiness.

[And it is said] by Tejahsiṃha [in Daivajñālaṃkrti 15.8]:

If Venus is strong, there is happiness from wife, fine clothes, good food and drink, health and all [manner of] delights; if it is middling, indeed, all is middling, and there is secret suffering; if it is poor, [the native] is the abode of every unhappiness and [suffers] the ridicule of people [in general].

And in Tãjikasāra [119-121 it is said]:

Being complete in strength, Venus will give good food, much delight from women, and laughter; and it will give the happiness of health and all delights, gain, well-being, prowess, victory, and a good mind. Middling [in strength, Venus gives] opposition from the king, one's own people, and enemies; it will make suffering from phlegm, danger to wife and children, evils, failure in enterprises, the arising of confusion and illness, and no happiness, at its period commences. If Venus is poor [in strength], there will certainly be quarrels with everyone, unhappiness from enemies and princes, loss of happiness and wealth, great sorrow and fear, and disputes; if burnt, disintegration of [the native's] mind during its period.

And detailed results [are described] in Hāyanasundara [208-233]:

If Venus is ruler of the year or aspected by or joined to [that ruler], there is gain of horses, vehicles, ornaments and so on, the birth of a daughter, and the native meets with prosperity in the form of merit, a wealth of objects, and illumination of intellect. 
bhrgutanayo ravināa yutadrșțah kaștạn vai jațharaṃ kurute| jvarabādhā ca śiro'rtir netre vā dusyato ripor bhītih $\|$ vapuși durbalatā nrpater bhayam dahanabhïtir amitrakṛtaḥ kalị̣| kim api kāsam upaiti dhanavyayam bhavati hāyanake raviyuk kavih \| candreṇa yutadrștaś ced bhārgavah paśunāśakrt | nakhadantaśirobādhām yāti kāmalapittatām | striyāh saukhyam avāpnoti kācid vātodbhavā vyathā $\|$ bhaumena yutadrștaś ced uśanā dhanaläbhakrt | pittaprakopatah pị̣̂ā nrpāal lābho 'tha yāmyatah | catușpadād bhayam kiṃcid anutsāho vicittatā $\|$ sitas tu jñena drșto vā yuto 'tha dhanalābhakrt | buddhiprakāso mitrādiputrotsāho 'dhimānyatā | cāturī caturo lābhạ syād udīcīdiśo dhruvam \| gurau śukreṇa yukte syāt suśíladrḍhadharmabhāk| punyatīrthapadaprāptir jñātibandhujanāt sukham || kuțumbibhih prakupito raudrídigjanitam sukham | labhate dhanasanmānam läbhạ syāt sitavastutậ $\|$ sitas tu śaniyukto 'tha vīkșito lābhadāyakah | puragrāmādhipatyam ca mitraprïtivivardhanam || vāruṇidigbhavo läbhạ krṣnavastukrto bhavet | jñātisambandhataḥ saukhyam daurbalyam vātavikriyā $\|$ śitajvaro jalād bhïtir mahișād aśvato bhayam | striyā jaratyā sambhogah sitaś cec chanidrștayuk \| sitas tamoyuto dhatte nakhadantaśirovyathām | pittakāmalatah kṣiṇah śarīre kleśam aśnute \| nairrtyān nīcato hānir jalasarpabhayam bhavet | śîtajvaropadravaḥ syān nīcasañgād dhanakșayaḥ \|

\footnotetext{
1 jațharaṃ] scripsi; jāțharam B N G K T M $\quad 2$ 'rtir] vartir G || dușyato] dușțato K T M 3 vapuṣi] vapușir $\mathrm{N} \|$ bhītir amitra] bhītimitra $\mathrm{T} \quad 5$ bhārgavaḥ] dhārgavaḥ $\mathrm{K} \quad 7$ avāpnoti] avāmoti N 9 pitta] pittaḥ B; pitaḥ N 10 vicittatā] scripsi; vicitratā B N K T M; viciṃtatā G 12 'dhimānyatā] dhimānitā B N K T M 14 dharma] karma G 16 prakupito] prakupite B N 17 sita] pīta G 18 śani] śaninā K T M \|| 'tha] om. B N K T M 19 prīti] prītir B N \| vivardhanam] vivardhanaḥ B N G K T 22 jalād] talād N 24 śirovyathām] virācyathāṃ $G$ 25 kāmalatah] kamalatah $\mathrm{N}$
}

17-18 vastutah ... yukto] In G, these words have been partly effaced using yellow paste. 
Joined to or aspected by the sun, Venus makes grave evils; ${ }^{64}$ there is affliction from fever and headache, or the eyes fail, and there is danger from enemies. There is weakness in the body, danger from the king, danger of fire and strife caused by enemies; moreover, [the native] suffers from cough and there is loss of wealth in [that] year, [if] Venus is joined to the sun.

If Venus is joined to or aspected by the moon, it destroys cattle; [the native] suffers afflictions of the nails, teeth, and head, and jaundice from [the humour of] bile. He receives happiness from a woman, [but] there is some pain caused by [the humour of] wind.

If Venus is joined to or aspected by Mars, it makes gain of wealth; there is suffering from agitation of bile but gain from the king and from the south; some danger from quadrupeds, listlessness, and mental confusion.

If Venus is aspected by or joined to Mercury, it makes gain of wealth; there is illumination of intellect, celebrations with friends, children and so on, great respect, and cleverness; there will certainly be swift gains from the northern quarter.

If Jupiter is joined to Venus, [the native] will possess good morals and firm [devotion to] religion; there is attainment of rank and [journeys to] sacred places, and happiness from family members and kinsmen. [He is] angry with members of his household, [but] there is happiness arising from the northeastern quarter; he gains wealth and respect, and there will be gain from white articles.

Joined to Saturn or aspected [by it], Venus gives gains; there is authority over a town or village, and increase of affection between friends. There will be gain from black articles in the western quarter, happiness on account of family members, [but] weakness and disorders of [the humour of] wind. There is fever with chills, danger from water, danger from buffaloes and horses, and intercourse with an old woman, if Venus is aspected by or joined to Saturn.

Joined to Rāhu, Venus gives afflictions of the nails, teeth, and head; [the native] wastes away through jaundice from [the humour of] bile, and suffers pain in the body. There will be loss in the southwest [or] from low people, danger from water and snakes, attacks of fever with chills, and loss of wealth from low company.

64 All text witnesses read jātharam 'of the stomach', but the metre requires jațaram 'grave'. 
sitas tu ketuyugdrșțah suhṛdbhir bāndhavaih kaliḥ| putrādikaștạn śatrubhyo vigraho nīcasamgamāt || hānir bhayam nairrteh syād rūkșavātaprakopatah | visphoțakā jalabhayam phaṇibhīr bhramamūrchatā $\|$ krșnavastumanușyād vā hāniḥ śvadaśanād bhayam | sitah ketuyuto drșțo 'śubham datte sadā phalam \|

iti śukraphalam \|

atha śaniphalaṃ varșatantre |

mande 'bdape balini nūtanabhūmiveśmakșetrāptir arthanicayo yavanāvanissát | ārāmanirmitajalāśrayasaukhyam añgapuștịh kulocitapadāptigaṇāgraṇitve \| abdādhipe ravisute khalu madhyavirye madhyam phalam nikhilam annabhujis tu kaștāt | dāsoștramāhișakudhānyarates tu läbhạ pāpaṃ phalam bhavati pāpayugīkșaṇena $\|$ mande balena rahite 'bdapatau kriyānām vandhyatvam arthavilayo vipado 'ribhïtih | striputramitrajanavairakadannabhuktih saumyetthaśálayuji saukhyam apișad āhuh \|

tejaḥsimhena |

mande jalāśrayamahīruharopakarmavānijyakrssyavatilabdhidhiyo 'dhivīrye | madhye tu madhyam adhame tu suhrdvipattih kaștạ̣ kriyāviphalatānilarugvikārāḥ \|

1 yugdṛșțah] yutdṛk G 3 rūkșa] scripsi; rakșa B N; rakta G M; rukșa K T 4 visphoțakā] visphoțakāj B N G K T \| mūrchatā] mūrddanāḥ G; mūrchanāḥ T 5 hāniḥ śva] hāniś ca B N KTM 9 balini nūtana] bali niruttama KT 10 āptir] āmir N 12 tve] tva K; tvaṃ T; tvam M 20 yuji] yuti N || apīṣad] așișad N || āhuh] āhạ̣ K T 21 tejaḥsiṃhena] tejaḥsiṃhaḥ G a.c. M; tejasiṃhah G p.c. KT 22 mande] mando B N KT M $\|$ mahī] maha B N 23 vati] vani G K T M \| dhiyo] yo K; payo T M 24 tu $^{2}$ ] su B; om N 25 kaștạ̣] kașța B K T M

9-20 mande ... āhuḥ] VT 1.34-36 22-25 mande ... vikārāḥ] DA 15.9 
[If] Venus is joined to or aspected by Ketu, there is quarrel with friends and relatives, evils to children and so on, and conflict with enemies through low company. There will be loss and danger from the southwest, boils from dryness and agitation of [the humour of] wind, danger from water, danger from snakes, confusion and stupor; loss from black articles or [a black] man, and danger of dog bites: joined to Ketu or aspected [by it], Venus always gives evil results.

This concludes the results of Venus.

\subsubsection{Saturn as Ruler of the Year}

Next, the results of Saturn [are described] in Varșatantra [1.34-36]:

If Saturn as ruler of the year is strong, there is acquisition of new lands, houses, and fields, accumulation of riches from a Yavana king, happiness from pleasure gardens and artificial ponds, bodily well-being, attainment of rank befitting one's family community, and leadership of an assembly. Indeed, if Saturn as ruler of the year is of middling strength, all results are middling, but [the native] has difficulty finding food to eat; there is gain from a fondness for servants, camels, buffaloes, and low-class grains; by the joining or aspect of a malefic, there are evil results. If Saturn as ruler of the year is bereft of strength, actions are futile; there is dissipation of wealth, misfortunes, danger from enemies, enmity with wife, children, and friends, and eating of bad food; if it forms an itthaśa $a$ a with a benefic, [astrologers] say there is a little happiness, too.

[And it is said] by Tejahsiṃha [in Daivajñälaṃkrti 15.9]:

If Saturn has great strength, there are thoughts of gain from ponds, planting trees, trade, farm land, and begging; if middling, [results are] middling; if poor, adversities to friends, evils, futility of actions, and disorders from illnesses of [the humour of] wind. 
tājikasāre 'pi |

mande 'bdape 'dhikabale vanaparvatāc ca

lābho mahān bhavati bhūruharopaṇāc ca|

vānijyakrsyapatito 'rthasamāgamaś ca

mlecchät khalān nijajanāt sukham atra nūnam \|

madhyah śanih svajanarājajanād virodham

vātārtikrjjațharaprșțagale ca netre |

dāridryaduhkhaparipīdanam atra kuryād

vairāgyam arthaparihānisuhrdvirodham \|

nindye 'tra sarvam adhamam tu suhrdvipattih

kaștạ̣ kriyāviphalatānilarugvikārāḥ|

kāryārthahānir atha putrasuhrrdvipattir

dagdhe 'rkaje bhavati damșțibhayam ca mrtyuh \|

viśeșaphalaṃ hāyanasundare |

varșapo yadi śanir bhayam ārtịh pị̣anam vapuși vātavikārāt |

putradārakalaho matihānir grāmayānam atibhīr jaladeśāt $\|$

nìcaprasamgatiś cintā hānị̣ paścimadeśatah |

krṣnakrayānakāa saurir datte varșe śubham phalam ||

raviyutadrșțah saurị̣ sutayuvatīkleśadas tanau kaștam |

mitravirodhodvegah pravāsitā vapuṣi durbalatā $\|$

jvarabādhā ca śiro'rtir nrpavahnibhayam tathā ca dhanahānị̂ |

syād udvego manujair mahadbhir api raviyute mande \|

śaśiyutadrșțah sauriryuvatìmaraṇāntakaștado bhavati |

kukșivyathām vidhatte dhananāśạn kiṃcid āpnoti $\|$

bandhuviyogaḥ kleśo mitraị kaphavātasambhavavikāraḥ|

2 bale] le N 3 mahān] mahā G 5 mlecchāt] śleșmāt B N; śleṣmā K T M || khalān] valān B N K T; balān M $\quad 7$-kṛj jațhara] -kṛttathara N 8 dāridrya] dāridra G 10 nindye] nindyaṃ N 12 vipattir] vipatti G 16 hānir] hīnir N \| yānam] ponam B N; om. K 17 prasaṃgatiś] prasangatā K 18 kṛ̣ṇa] kṛșțaṃ M \| krayāṇakāt] kṛāṇakāt G K M || saurir] saurī $\mathrm{K} \|$ varșe śubhaṃ] vaśubheṃ $\mathrm{N} \quad 25$ bandhu] vadhu T \| kleśo] leśo $\mathrm{N}$

2-13 mande ... mrrtyuh] TS 122-124 15-520.23 varșapo ... bhavet] HS 224-240 
[And] in Täjikasāra [122-124 it is said]:

If Saturn as ruler of the year has great strength, there is much gain from forests and mountains, and from the planting of trees; there is acquisition of riches from trade, farm lands and rulers, ${ }^{65}$ and happiness, indeed, from foreigners, scoundrels, and one's own kin. Middling [in strength], Saturn will make opposition from one's own people and princes, afflictions from [the humour of] wind in the stomach, back, throat, and eyes, torments of poverty and suffering, aversion, loss of wealth, and opposition from friends. If [the strength of Saturn is] poor, everything is bad: adversities to friends, evils, futility of actions, disorders from illnesses of [the humour of] wind, loss in undertakings and wealth, and adversities to children and friends. If Saturn is burnt, there is danger from a wild boar and death.

Detailed results [are described] in Hāyanasundara [224-240]:

If Saturn is ruler of the year, there is fear, suffering, pain in the body from disorders of [the humour of] wind, quarrels with wife and children, loss of reason, travel to a village, ${ }^{66}$ and great fear from a watery place. There is low company, anxiety, and loss from the western quarter; [but] Saturn in [its] year gives good results from trade in black articles.

Joined to or aspected by the sun, Saturn gives suffering from wife and children; there are evils of the body, agitation from the opposition of friends, living abroad, and weakness in the body. There will be suffering from fever and headache, danger from princes and fire, and also loss of wealth and agitation caused by great men, if Saturn is joined to the sun.

Joined to or aspected by the moon, Saturn gives evils even unto the death of [the native's] wife; it produces stomach pains, and [the native] suffers some loss of wealth. There is separation from kinsmen, distress

65 All text witnesses of the Hāyanaratna, and some independent witnesses of the Täjikasāra, read patito 'from rulers', while other independent witnesses read vanitā '[from] women'. Very likely the original reading was the more unusual vatito 'from begging', to harmonize both with Tejaḥsiṃha's text (and/or its source, presumably Samarasiṃha) and with the astrological symbolism of Saturn.

66 Or, possibly but less likely, from a village. Either meaning seems incongruous, and some text witnesses give variant readings, but none that suggests a useful emendation. 
hānir vāyavyadiśạ svalpasukham vaiśyato 'lpabhayam ||

bhaumayutadrștasaurịh sthānabhraṃso 'gnitaskarādibhayam |

saha bāndhavair virodho dhanahānir dakșinadiśātaḥ $\|$

na viśvāsyau svarnakārakșatriyau dhanahānidau|

raktavātavikārah syāt saurinā mañgale yute \|

budhayutadrșto mandaḥ karoti saubhāgyasaukhyadhanalābham |

hemādilābhasutajanmamānyatāthottarādiśo lābhạ̣ \|

guruyutadrsțtas tu śanir gurudevaratạ suvarnadhanalabdhị̣|

saukhyam tìrthaprāptir mahāpadāptiś ca raudrītạ $\|$

strīsañgāt sukhavrddhị̣ syād grāmabhümyarthalābhakrt |

lābhah pūrvadiśo bhūyāt saurir guruyutekșitah \||

sitayutadrșțah krodah suhrtprasangah sahodarair maitrī |

lābhah sutādisammatir āgneyadiśo bhavel lābhạ̣ ||

prìtir añganayātyantam mānañyah kule bhavet |

kaphādivikriyā saurị śukrena yutavīkșitậ \|

rāhuṇā yutadrșto 'rkih samnipātarujākarah |

mürchā ca śîtalārogah pittakopo 'ngapịdanam \|

jalasarpāribhïr nīcasambandhād dhanasaṃkșayah |

nairrtyāṃ dhanahāniḥ syād atīsārabhramāov api $\|$

syāt ketuyutadrșțas tu śanir vātaprakopakrt |

vigrahaḥ sutamitrādyaịn kleśạ punyaparikṣayaḥ \|

pāpavrddhir athodvego nīcād duḥkham avāpnuyāt |

ägneyinairrtìdeśäd dhanahānị̣ kvacid bhavet \|

iti śaniphalam | tājikasāre sthānaviśeșeṇāpi varṣeśaphalam uktam |

sadmoccageșu paripūrnaphalaṃ khageșu

haddātribhāgakanavāmśagateșu madhyam |

2 bhauma] bhaumena K T M $\|$ dṛșța] dṛsțahạ B N K T M 4 viśvāsyau] viśvāsau B N; viṃdyāt saukhyaṃ K T 6 saubhāgya] om. G || lābham] lābhāḥ B N; lābhaḥ K T 7 mānyatā] scripsi; amātyato B N G M; āmātyato K; āṃmātyato T 11 bhūyāt] bhūyān G K T M 14 aṅganayā-] agatayā- B; agatathā- N \| mānanīyaḥ] mānīyah B N 15 śukreṇa] śukreyā $G$ 18 bhīr nīca] bhìtī ca G 19 nairṛtyāṃ] nairṛtyād M || bhramāv] bhramād B N K T M 21 punya] purā $G$ p.c. 22 athodvego] athodvegī $G \quad 24$ varșeśa] vargeśa $G$

25-522.2 sadmocca ... samantāt] TS 125

7 hemādi ... lābhah] The emendation, required by both sense and metre, is supported by MS HS1. The caesura following the initial short syllable of the 4th foot (gana) conforms to the 'old $\bar{a} r y \bar{a}$ ' identified by Jacobi. 
regarding friends, disorders arising from [the humours of] phlegm and wind, loss from the northwestern quarter, little happiness, and a little danger from commoners.

[If] Saturn [is] joined to or aspected by Mars, there is loss of place, danger from fire, robbers and so on, opposition from relatives, and loss of wealth from the southern quarter. Goldsmiths and nobles are not to be trusted, [but] cause loss of wealth. There will be disorders of blood and [the humour of] wind, if Mars is joined by Saturn.

Joined to or aspected by Mercury, Saturn makes good fortune, happiness and gain of wealth. There is gain of gold and so on, the birth of a son, respect, and gain from the northern quarter.

[If] Saturn is joined to or aspected by Jupiter, [the native] is devoted to teachers and gods; there is gain of gold and wealth, happiness, a visit to a sacred place, and attainment of great rank from the northeast. There will be increase of happiness from the company of women; [Jupiter] makes gain of a village, land, and wealth; there will be gain from the eastern quarter, [if] Saturn is joined to or aspected by Jupiter.

[If] Saturn is joined to or aspected by Venus, there is interaction with friends, friendship with siblings, gain, and harmony with children and so on; there will be gain from the southeastern quarter. There is abundant affection from a woman; [the native] will be honoured in his family community, [but there are] disorders from [the humour of] phlegm and so on, [if] Saturn is joined to or aspected by Venus.

Joined to or aspected by Rāhu, Saturn makes compounded illness, fainting, small-pox, agitation of bile, and pain in the body. There is danger from water, snakes, and enemies, and loss of wealth due to low company; there will be loss of wealth in the southwest, dysentery and confusion.

Should Saturn be joined to or aspected by Ketu, it makes agitation of [the humour of] wind, discord with children, friends and so on, suffering, and loss of merit. There is an increase of evil, agitation, and [the native] meets with suffering from low persons; sometimes there is loss of wealth from the southeastern or southwestern quarter.

This concludes the results of Saturn. In Tãjikasāra [125], moreover, the results of the ruler of the year are described according to its particular position:

When planets occupy their domiciles or exaltations, the [good] results are complete; when they occupy their haddās, thirds, or ninth-parts, 
nīcāriveśmasahiteșu ca dagdhavīryam

astārigeșu khalu nașțaphalaṃ samantāt \|

atrāyam viśeșạ̣ | yadi varṣeśena krūragraha itthaśālaṃ karoti tadā varṣeśasya śubhaphalaṃ pūrṇam aśubhaphalaṃ nyūnaṃ jñeyam | yadi varșeśena krūragraha īsarāphaṃ karoti tadā aśubhaṃ pūrṇaṃ phalạ̣ śubhaphalạ̣ nyūnam jñeyam iti | iti varșeśaphalaṃ samāptam ||

athāriștavicārah | tatroktaṃ vakṣyamāṇaṃ vā varșaphalaṃ saty ariște vṛthā mariṣyamāṇatvāt tasyety āha maṇitthạ |

vrthā phalaṃ hāyanajaṃ ca yasmān na jīvanam hāyanariștayogāt |

rișțāni tasmāt prathamam pravakșye pūrvair vidhijñaị̆ kathitāni yāni $\|$

muktāvalyām api |

riștāni ced varșaphale bhavanti tadā vṛthā varșavicāraṇā syāt | sabhañgariștasya vinirnayo 'tah śișyāvabodhāya nirūpyate 'tra \|

maṇitthạ |

2 astārigeșu] astādigeșu K T M \| phalaṃ] valaṃ $\mathrm{G} \|$ samantāt] sama tat $\mathrm{N} \quad 3$ varșeśena] saha add. G 5 graha īsarāphaṃ] grahesarāphaṃ $\mathrm{G} \|$ pūrṇaṃ phalaṃ] phalaṃ pūrṇaṃ $\mathrm{G}$ 10 pūrvair] pūrṇair $\mathrm{B} \mathrm{N}$

9-10 vṛthā ... yāni] VPh 19; HS 42 12-13 rișțāni ... 'tra] TM 70 
middling; when they are joined to their fall or enemy houses, their strength is consumed; indeed, when they are [heliacally] set [and also] in inimical [signs] ${ }^{67}$ the [good] results are entirely lost.

Concerning this, there is the following distinction: if a malefic planet makes an itthaśäla with the ruler of the year, then the good results of the ruler of the year should be understood to be full, and the evil results, slight; [but] if a malefic planet makes an isarāpha with the ruler of the year, then the evil results of the ruler of the year should be understood to be full, and the good results, slight. This concludes the results of the ruler of the year.

\subsection{Unfortunate Configurations}

Next, the consideration of misfortune. ${ }^{68}$ On that matter, Manittha states [in Varșaphala 19] that when [an indication of] fatality is present, the results of the year - whether [those already] described or described below - are to no avail, as that [native] is going to die [before they manifest]:

Because [there will be] no life due to a fatal configuration in a [revolution of the] year, the results arising from [that] year are to no avail. Therefore I shall first explain the fatal [configurations] described by the astrologers of old.

And in [Täjika]muktāvali [7o it is said]:

If there are fatal [configurations] in the revolution of the year, then judging [other results of] the year is to no avail. Therefore, the judgement of fatal [configurations] along with [their] cancellations is described here for the instruction of students.

[And] Manittha [says in Varșaphala 2o]:

67 Text witnesses K T M read '[heliacally] set and so forth'.

68 Although rișta or arișta can refer to misfortune in a broad sense, it often has the sense of life-threatening danger or fatality. See the Introduction. 
lagnādhināthe mṛtibhāvasamsthe bhaumekșite tasya ca bhāvasaṃsthe | astamgate vā bhrguje budhe vā śastrābhighāto bahudhāpadaś ca \|

tasya bhāvasamsthe lagnādhīśe bhaume cāșțamasaṃsthe ity arthạ̣|

rātrišsvare bhäskaramaṇ̂lalasthe șașthe vyaye vā mrtibhāvasamsthe | tridoșato 'sau bahubhị̣ prakāraị karoti kaștam vividham daśāyām || varșalagnaparandhreśau caturthanidhanāntyagau | muthahāsamyutau yatra tadvarșe maraṇapradau || cej janmanātho vibalo mrtīso lagnam gato bhāskaradṛ̦țamūrtị̣ | śastrābhighāto bahudhā ca kaștam kaștam śarīre maraṇena tulyam \| muthahālagnanāthau cet sūryamaṇdalam àgatau| drșțau tau sūryaputreṇa sarvanāśakarau matau \| yogo yadā müsaripho grahendrair duștaiḥ kṛtah saumyakrtạ̣ kabülaḥ| janmādhipaḥ krūrayutas tadānīm mahārthanāśam maraṇena tulyam \| balotkațāh krūrakhagā balena hīnāyadā saumyakhagās tadānīm | duḥkham mahāryādhikrtam ca vairam parasparaṃ śatruvimardanam ca \| daityendrapüjyo yadi nīcasamsthạ

sureśapūjyo ripubhāgavartī| svapne 'pi saukhyam na hi varșamadhye vrthā phalam hāyanajam tadānīm || astaṃgatau bhārgavasomaputrau nīcasthito rātripatir yadā syāt | tadā viyogam maranam ca kaștạn śarīrapịdām atulām karoti \| janmalagnād varșalagnam aștamaṃ yadi jāyate | tasmin varșe bhavet pị̣̂a mrtyuḥ pāpayutekșaṇāt ||

4 rātrīívare] rātrīśvaro N $\|$ maṇḍala] maṃla N $\quad 5$ 'sau] 'ptau G 8 dṛșța] dṛsți K T M 9

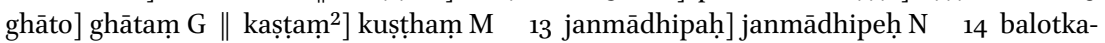
țāḥ] balotkarāḥ K T M \|| khagās] raveṇas K; raves M 15 vyādhi] trādhi K T || parasparaṃ] parasyo K 16 nīca] jīva K 17 sureśa] surejya K T M \| pūjyo] pūjye K T 19 hāyanajạ̣] hāyanajāt K T 21 viyogam] ] yovigaṃ $\mathrm{T}$

1-2 lagnā ... ca] VPh 20; HS 43; cf. HS 285 4-5 rātrîśvare ... daśāyām] VPh 21; HS $44 \quad 6-7$ varșa ... pradau] VPh 22; HS 45, 242, 246 8-9 cej ... tulyam] VPh 24; HS 47 10-11 muthahā ... matau] VPh 26; HS 49, 243 12-13 yogo ... tulyam] VPh 30; HS 53 14-19 balotkațāh ... tadānīm] VPh 38-39; HS 6o-61 20-21 astam ... karoti] VPh 40; HS 62 
The ruler of the ascendant occupying the eighth house, aspected by Mars and occupying its house, with either Venus or Mercury being [heliacally] set, there is injury from weapons and misfortunes of many kinds.

'Occupying its house' means that the ruler of the ascendant and Mars are [both] in the eighth. [Continuing from Varșaphala 21-22, 24, 26, 30, 38-39, 40:]

If the moon is placed within the orb of the sun, occupying the sixth, twelfth, or eighth house, it makes manifold misfortunes from [all] three humours in many ways in its period. In that year in which the ruler of the ascendant of the year and the ruler of the eighth house occupy the fourth, eighth or twelfth house, joined to the munthaha, they cause death.

If the ruler of the nativity is weak and the ruler of the eighth house is in the ascendant, its body aspected by the sun, there is injury from weapons and evils of many kinds; evils ${ }^{69}$ in the body equal to death.

If the rulers of the munthaha and the ascendant have come within the orb of the sun and are aspected by Saturn, they are considered to destroy all things.

When evil planets form the müsarihpha configuration, benefics form a kambüla, and the ruler of the nativity is joined to malefics, then there is great loss of wealth, equal to death.

When the malefic planets abound in strength and the benefic planets are bereft of strength, there is suffering caused by severe illness, hostility, and enemies destroying each other. If Venus occupies its fall and Jupiter traverses the [zodiacal] division of an enemy, in that year there is no happiness even in dreams, and the [expected] results of the year come to nothing.

When Venus and Mercury are [heliacally] set, and the moon occupies its fall, then [that configuration] makes separation, an evil death, and unequalled pain in the body.

If the eighth [sign] from the ascendant of the nativity becomes the ascendant of the year, there will be suffering in that year: death, if malefics join or aspect. ${ }^{70}$

$69 \quad$ Text witness $M$ reads 'leprosy'.

70 This last verse is not attested by available independent witnesses of the Varșaphala. 
așțamalagne muthaheśvarayogo niṣiddha iti tājikasāre |

śukrejyauyadi cāstagau himarucir nīcānugaś cet tadā kuryād vyādhibhayaṃ viyogam aśivam kaștam mahad dāruṇam | chidreśo yadi lagnagas tanupatiś chidrānugaś cet tadā drștau tau khalakhecarair nidhanadau śastrād bhayam syāt tatah \|

haddeśvaro hāyanalagnanāthạ̣ saptāntyagạ̣ krürayutạ̣ karoti | mrtim daśāyām śubhayuktadrștah phalam tadardhapramitam karoti $\|$ nīce trirāsyädhipatih parasya gehe 'tha pāpena vilokitaś ca| kāryasya nāśam kurute hy akasmād vairam ca kaștam paratạ sadaiva \| purenthiheśo ravimaṇdalastho yadā tadaivam pravadanti santạ̣ | șașthāștamasthe nanu varșanāthe mahābhayaṃ bhüpakṛtaṃ ca kaștam \| yadāṃśubhāge śaśije kabūle mandena sārdham na sukham kadācit | kalatrahānim maranam ca duḥkhạ̣ karoti vairam bahudhā narānām || krürah khago yo 'stamito 'tha vakrī krūrasya varge yadi lagnanāthah | krūras tadā bhañgam uśanti tajjñāh purasya vairaị purato vināśam ||

2-5 śukrejyau ... tatah] om. G KT M 4 patiś] pati B 7 dṛșțah] dṛsțị̣ KT M || tad] stad B N || ardha] arddham B N; ardham K T M || pramitam] pratimaṃ G K T M 10 pure-] pareK T M || maṇḍalastho] maṇḍalasya K M $\|$ tadaivam] tad evam K T M 11 -sthe] -stho N || bhayaṃ] bhayaḥ $\mathrm{G} \|$ bhūpa] bhūta M 12 yadā-] tadā- K T M || sārdhaṃ] sārdhe K T \| na] ma K 13 hāniṃ] hābhi N; hānir K T 14 varge] garve K T M 15 bhangam] bhagnam K T M \|| purasya] puraṃ ca K T M \| vairaiḥ] vairaṃ B N G T M \| vināśam] vināśah B N; vinās̄ạḥ G; vināśa T

2-5 śukrejyau ... tatah] TS $146 \quad 6-7$ haddeśvaro ... karoti] VPh 23; HS $46 \quad 8-9$ nīce ... sadaiva] VPh 68-69 10-11 pure- ... kaștạm] VPh 45; HS 67 12-13 yadā ... narāṇām] VPh 43; HS 65 14-15 krūrah ... vināśam] VPh 46; HS 68

${ }^{2-5}$ śukrejyau ... tatah] B N, the only witnesses to include this stanza from the TS, insert it in the middle of the foregoing quotation from the VPh.

71 A tentative translation of a syntactically problematic phrase. The actual quotation from the Tajikasāra is present only in the two earliest text witnesses (B N), where it is misplaced, and does not mention the munthaha (though it does occur in a section of that work dealing with results of the munthaha $)$. There is thus reason to suspect some textual corruption.

72 The Varșaphala does not specify which are the relevant terms (haddā) in this context. Most likely, the underlying original concept is that of directions ( $\ddot{\alpha} \varphi \varepsilon \sigma \iota \varsigma$, Arabic tasyir $r$ ) through the terms, not generally understood by Täjika authors. Depending on the extension of the terms in question and the latitude of birth, a significator such as the ascendant will take a number of years to pass through them, during which time 
According to Tajikasāra [146], the ruler of the munthahā joining the eighth [house and] the ascendant ${ }^{71}$ is forbidden:

If Venus and Jupiter are [heliacally] set, and if the moon occupies its fall, then [that configuration] makes dangerous illness, unhappy separation, great and cruel evils. If the ruler of the eighth house is placed in the ascendant, and if the ruler of the ascendant occupies the eighth house, both aspected by malefic planets, then they cause death: there will be danger from weapons from that [configuration].

[Continuing from Varșaphala 23, 68-69, 45, 43, 46:]

The ruler of the hadd $\bar{a}^{72}$ [or] the ruler of the ascendant of the year placed in the seventh or twelfth house joined to malefics causes death in its period. Joined to or aspected by benefics, it limits the result to half of that. ${ }^{73}$

The ruler of the triplicity in its fall or in another's domicile, aspected by a malefic, makes the sudden failure of an undertaking, and constant, severe enmity with others.

When the ruler of the inthiha $\bar{a}$ is about to enter ${ }^{74}$ the orb of the sun, then the wise [astrologers] declare the same. Indeed, when the ruler of the year is placed in the sixth or eighth [house], there is grave danger and evils caused by the king.

When Mercury is in a kambüla with Saturn within its orb of light, there is never any happiness: it makes men lose their wives [and causes] death, suffering, and enmity of many kinds.

If a malefic planet that is [heliacally] set or retrograde, in the division of a malefic, is the malefic ${ }^{75}$ ruler of the ascendant, then experts declare defeat and destruction by enemies before the town.

the ruler of the terms (known as the divisor, translating al-qāsim, or as algebuthar, a Latinization of the Perso-Arabic al-jär bakhtār which in turn translates xpovoxpó $\tau \omega \rho$ 'ruler of the time') is considered a major influence on the native's life. Cf. Chapter 4 , notes 37 and 90.

73 What would constitute 'half the result' of dying is not altogether clear.

74 Or: 'When the ruler of the inthihā of the town occupies'. Although such a meaning may seem far-fetched, the word pura 'town' recurs a few verses below.

75 This superfluous 'malefic' (krūras) is attested by all text witnesses. Possibly it should read krüram, to agree instead with bhangam: 'cruel defeat'. 
varșatantre |

lagneśe 'ștamage 'șteśe tanusthe vā kujekșite |

jñajivayor astagayoḥ śastraghāto vipan mrtị \|

krūramūsaripho 'bdeśojanmeśậ krūritạ̣ śubhaị| |

kambūle 'pi vipan mrtyur ittham anyādhikāritah \|

lagneśe 'ștamage 'șteśe tanau ca mrtim ādiśet |

inthiheśe 'bdape vāribhe 'stamyāte rujā vipat ||

janmany aștamagaḥ pāpo varșalagne rugādhidaḥ|

candrābdalagnapau naștabalau cet syāt tadā mrtiḥ \|

vyayāmbunidhanāristhā janmeśābdapamunthahāh|

ekarkṣagās tadā mrtyuḥ pāpakṣutadṛśā dhruvaḥ \|

janmābdalagnapau pāpayuktau patitabhasthitau|

rogādhidau mrtyukarāo astagau nekșitau śubhaih \|

abdalagnād rijvanrjūu vyayārthasthau rujau khalau|

evaị varsābdalagneśajanmeśair api bandhanam \|

lagnam pāpakhagāntare yadi gatạ̣ dyūnaṃ tathā mṛtyukṛt iti tājikasāre saptame 'pi kartarī nișiddhoktā | hāyanasundare |

1 varșatantre] om. N 2 kujekșite] kuje kșitau K M 3 jivvayor] śukrayor N; jivavayor K \| vipan] vibhapaṃ N; pivan $\mathrm{K} \quad 4$ mūsaripho] mūsariphe $\mathrm{N} \quad 5$ mṛtyur] mṛttir K 6 'șteśe] șteśo B N a.c.; śe G 7 inthiheśe] ị̣thiheśo B N; inthiheśo K; itthiheśo T \| vāri] vāpi $\mathrm{KT}$ \| bhe 'staṃ] masta K; bhastaṃ M \|| yāte] jāte K || rujā] hajā K \| vipat] viyat T 9 candrā] janmā KM $\|$ mṛtiḥ] tiḥT 10 janmeśā] janmeśo N; tanośā K 11 kṣuta] mukta KT \| dṛsáa daśā K T M || dhruvaḥ] dhruvaṃ K T M 12 pāpa] māpa K || yuktau] yukto KT || bha] ma KT 13 ādhidau] ādhipo N || karāv] varāv N || nekșitau] nekșatau B N; nekșitai K; nekșitaih T M 14 vyayā-] riṣphā- K T; riḥphā- M \| rujau] scripsi; rujā B N K T M; rujaḥ G \| khalau] khilau B N; tadā KT M 15 lagneśa] lagneśe KT \| janmeśair] janmeśor K; janmeśaur T ${ }_{16}$ lagnaṃ] lagne K T M || pāpakhagāntare] pāyasvanāntare K || dyūnaṃ] puta K; puṃje M || tājikasāre] jātakamāre K; jātakasāre M 17 'pi] mi K \| nișiddhoktā] ticiddhoktā K; ticidbhoktā T

2-3 lagneśe ... mṛtiḥ] VT 3.1 $\quad 4-5$ krūra ... kāritạ̣] VT 3.5 $\quad 6-7$ lagneśe ... vipat] VT 3.18 8-9 janmany ... mṛtị̣] VT 3.11 10-11 vyayāmbu ... dhruvaḥ] VT 3.13 12-13 janmābda ... śubhaih] VT 3.12 14-15 abda ... bandhanam] VT 3.17 16 lagnaṃ ... mṛtyukṛt] TS 149

76 Text witness $\mathrm{N}$ reads 'Venus'.

77 That is, the other planets with a claim to rulership in the year: the domicile and triplicity rulers of the ascendant and the ruler of the sect light (the sun by day, the moon by night) in the annual revolution. 
[And] in Varșatantra $[3.1,5,18,11,13,12,17$ it is said]:

If the ruler of the ascendant occupies the eighth, or the ruler of the eighth occupies the ascendant, aspected by Mars, while Mercury and Jupiter $^{76}$ are [heliacally] set, there is wound from a weapon, misfortune, and death.

[If] the ruler of the year has a müsarihpha with a malefic and the ruler of the nativity is afflicted, even if there is a kambüla with benefics, there is misfortune and death. It is thus [even] with the other [planets] in authority. ${ }^{77}$

If the ruler of the ascendant occupies the eighth, and the ruler of the eighth, the ascendant, one should predict death. If the ruler of the inthiha or the ruler of the year is [heliacally] set in an enemy sign, there is illness and misfortune.

A malefic occupying the eighth of the nativity [being placed] in the ascendant of the year gives illness and anxiety. If the moon and the ruler of the ascendant of the year ${ }^{78}$ have lost their strength, then death will occur.

[If] the ruler of the nativity, the ruler of the year, and the munthaha occupy a single sign in the twelfth, fourth, eighth or sixth house, then, by a kșuta aspect from a malefic, death is certain.

The ascendant rulers of the nativity and the year, joined to malefics and occupying ruinous signs, give illness and anxiety; they cause death [if also heliacally] set and not aspected by malefics.

Two malefics, direct and retrograde, placed in the twelfth and second house from the ascendant of the year, [respectively], afflict [the native with illness]; with the rulers of the year, of the ascendant of the year, and of the nativity being thus, there is imprisonment.

Besiegement ${ }^{79}$ even of the seventh [house] is declared in Täjikasāra [149] to be forbidden, with the words: 'If the ascendant, or likewise the descendant, is placed between malefics, it causes death.' [And] in Hāyanasundara [291 it is said]:

78 Text witnesses $\mathrm{K}$ M read 'the ascendant rulers of the nativity and the year'.

79 Kartarī, lit. 'scissors'. Kartarī-yoga is the standard Sanskrit term for the configuration known in western nomenclature as besiegement, where a horoscopic point is found between two planets of the same nature. 
syāt krūrakartariyuto lagneśo rājarogabhayakārī | iti |

tājikabhūṣaṇe |

kṣmāsutekșitayutas tanubhartā syān mrtisthitikaro mritikartā | sūryaluptakiraṇau dhiṣanajñau śastrapịdanakarau ca narānām \| cen munthahā pāpayutā șadaștaryayopagā hetihutāśabhītim | karoti varșe ravinandanena yutekșitā vā pavanaprakopam \| madananidhanabandhuprāntaśatrusthitā cej jananasamayalagnād inthihābde 'ștamasthā | khalagaganacaraiś ced yuktadrșțātiriștam janayati śubhadrștotpannariștālpatā syāt \| 10 kāminībhavanagas tuhināṃśur lagnapo mrtipatir yadi samsthah | dvādaśe dviși tathāyuși riștam syān mṛtau ca tanupo muthaheśạ \| janmarkṣanātho nidhane 'bdalagnāt syān mrtyukṛt krūrayutekșitaś ca \|

hillājadīpikāyām |

krūrasya hadde sitaguh sapāpaḥ kendre na drșțaś ca śubhair mṛtị̣ syāt | samandalagne dyunage mahïje varșe naro 'sau yamasadma yāti $\|$ kșapādhave krūrayute dyunasthe samastadṛturyalavena drsțte | vinaștapāpena ca niścayena varșe naro 'sau yamasadma yāti $\|$

\footnotetext{
1 yuto] patī K T || lagneśo] lagneśa B N || rājaroga] rājayoga B; rājayo roga N; rājyaroga M || kārī| iti] karoti K T M 2 tājika] jātaka K T M 3 yutas] yuta K T M || tanu] lagna K T M \| karo] karau G 4 lupta] lama K; lagna T \|| dhiṣaṇa] maṇa K || ca] hi K T M \|n narāṇām] marānāạ K 5 cen munthahā] ced ithihā K T; ced inthihā M \| pāpa] yā K; yāpa T || vyayopagā] vyayopayoge K T \| heti] yeti B N || hutāśa] jatāśā K || bhītim] bhītīh K T; bhītị̣ M 6 yutekṣitā] yujekșite K T \| pavana] pacana K T \| prakopam] prakopah K T 7 prānta] scripsi; prāpti B N; prāṃtya G T M; māṃtya K 9 gaganacaraiś] svagatavasthaur K \| ced] om. K 10 dṛștotpanna] dṛsțotyaṃta B N || rișțā] rișțo K T 11 bhavanagas] bhavanagatas B N || tuhināṃśur] tu himāṃśu K T M 12 āyuṣi] āyubi N; ātryuṣi M 13 nātho] nāthau G || ca] cet K T M 15 hadde] scripsi; haddā B N G T M; ruddā K \| sapāpạ̣] sa yo yaḥ KT \| kendre na] kendreṇa K T M \| dṛștaś ca] dṛșțona M \| śubhair] śubhe K T 16 dyunage] dyumage N || sadma yāti] gnathāmi K 17 kṣapādhave] lagnādhipe K T M || dyunasthe] dyūnākhye K; dyunākhye T M \| dṛkturya] dṛkrūrya B; dakrūrya N || lavena] balena M 18 pāpena ca niścayena] pāpaṃ navatiś ca yena K T M
}

1 syāt ... kārī] HS $291 \quad$ 3-4 kṣmā ... narānāām] TBh $6.4 \quad 5^{-12}$ cen ... muthaheśaḥ] TBh 6.6-8 15-532.2 krūrasya ... mṛtiḥ] HD 7.12-14 
Besieged by malefics, the ruler of the ascendant will make danger of consumption.

[And] in Tãjikabhūṣaṇa [6.4, 6-8 it is said]:

Aspected by or joined to Mars, the ruler of the ascendant taking its place in the eighth house causes death; and Jupiter and Mercury, deprived of their rays by the sun, make suffering from weapons for men.

If the munthahā, occupying the sixth, eighth or twelfth house, is joined to malefics, it makes danger from weapons and fire in [that] year; or, if it is joined to or aspected by Saturn, agitation of [the humour of] wind. If the inthiha, occupying the eighth [house of the revolution] of the year, [simultaneously] occupies the seventh, eighth, fourth, twelfth or sixth house from the ascendant at the time of the nativity, and if it is joined to or aspected by malefic planets, it gives rise to grave misfortune; [but if] aspected by benefics, the misfortune engendered will be slight. If the moon is placed in the seventh house, the ruler of the ascendant [and] the ruler of the eighth house occupying the twelfth, sixth or eighth house, there will be misfortune, and [likewise if] the ruler of the ascendant [and] the ruler of the muthaha are in the eighth house.

The ruler of the sign [occupied by the moon] in the nativity in the eighth house from the ascendant of the year will cause death if joined to or aspected by malefics. ${ }^{80}$

[And] in Hillājadīpikā [7.12-14 it is said]:

[If] the moon is in the hadd $\bar{a}$ of a malefic, with a malefic, and in an angle, not aspected by benefics, death will occur. If Saturn is in the ascendant and Mars is placed in the descendant, in that year the man goes to the abode of Yama. ${ }^{81}$ If the moon, joined to a malefic, is placed in the descendant, aspected by a corrupt malefic with a full [or] quarter aspect, ${ }^{82}$ in that year certainly the man goes to the abode of Yama.

8o This last sentence is not attested in available independent witnesses of the Tãjikabhūṣaña.

81 The god of death and ruler of the netherworld.

82 This probably means an opposition (considered to have full strength) or a square aspect. 
kujatamo'rkasutāh sukham āśritā yamapuram sa naraḥ parigacchati | mrtigatas tv aśubho 'śubhadrșțiyug vigata ijyadrśābdagatā mrtị̣ \|

tājikasāre |

lagnāstāntyașaḍaștago himarucir drșțaḥ khalaih saṃyutặ syād riștam prakaroty asau ca guruṇa no vīkșitah saddrśā | kașțạn syāc chaninā kujena dahanāc chasträd bhayaṃ vā viduḥ saṃdrștah prakaroti saumyakhacaraih saukhyapradah śobhanaḥ \| randhreśo 'tha vilagnapo yadi vidhor lagnād vyayāșțārigo no saumyair avalokito nidhanakrn munthädhipo vā tathā

daivajñālaṃkṛtau |

candreśalagneśamrtîśvarāś ced vyayārimrtyūpagatā vilagnāt | mrrtyupradā janmapamunthaheśau mrtyusthitau krūranirīkșitau tathā ||

ity arișțavicārah ||

athārișțabhangah | varșatantre |

\footnotetext{
1 puraṃ] karaṃ B N G K T 4 lagnāstāntya] lagnāstyaṃtya B; lagnostyaṃtya N || șaḍașțago] șạ̣ago T 5 rișțaṃ] ișțaṃ T M 8 lagnād vyayāșțārigo] lagnād vyayārișțago $\mathrm{K}$ T M 9 no] tau K T M \| avalokito] avanākitau M $\quad$ 10 daivajñā-] daivā- B N K T M 12 janmapa] nanmapa $\mathrm{N} \|$ munthaheśau] thamuṃheśau $\mathrm{N}$

4-7 lagnā ... śobhanaḥ] TS $148 \quad 8-9$ randhreśo ... tathā] TS $15^{2}$
} 
[If] Mars, Rāhu and Saturn have resorted to the fourth house, that man reaches the city of Yama. And [if] a malefic occupies the eighth house, with the aspect or conjunction of [another] malefic, turned away from the aspect of Jupiter, death takes place in that year.

[And] in Täjikasāra [148, $15^{2}$ it is said]:

Should the moon occupy the ascendant, descendant, twelfth, sixth or eighth house, aspected by or joined to malefics, it brings about misfortune, unless aspected by Jupiter with a good aspect. Should it be aspected by Saturn, it is known to bring hardship; by Mars, danger from fire or weapons; [but aspected] by benefic planets, it is auspicious and bestows happiness.

If the ruler of the eighth house or the ruler of the ascendant is placed in the twelfth, eighth or sixth house from the moon or the ascendant, not aspected by benefics, it causes death, and so, too, the ruler of the munthahā.

[And] in the Daivajñālaṃkrti [it is said]:

If the ruler of the moon, the ruler of the ascendant, and the ruler of the eighth house occupy the twelfth, sixth or eighth house from the ascendant, they bestow death; so, too, the ruler of the nativity and the ruler of the munthahā occupying the eighth house and aspected by malefics. ${ }^{83}$

This concludes the consideration of misfortune.

\subsection{Cancellation of Misfortune}

Next, the cancellation of misfortune; [and it is said] in Varșatantra [4.2, 1, $4-5,7,6,8]$ :

83 This verse is not attested in available independent witnesses of the Daivajñālaṃkrti. 
guruḥ kendre trikone vā pāpādrșțah śubhekșitaḥ| candralagnenthihāriștạn vinaśyārthasukhe diśet $\|$ lagnādhipo balayutah śubhekșitayuto yadā | kendratrikonago 'riștam nāśayet sukhavittadaḥ \| lagne dyuneśas tanugah surejyah krürair adrștah śubhamitradrștah | riștam nihatyārthayaśaḩsukhāptị̣ diśet svapāke nrpatiprasādam \| balānvitau dharmadhanādhināthau krūrair adrșțau tanugau tadā syāt | rājyam gajāśvāmbararatnapūrnam riștasya nāśo 'py atulam yaśaś ca \| yadā savīryo muthahādhinātho lagnādhipo janmavilagnapo vā | kendratrikonāyadhanasthitās te sukhārthahemāmbaralābhadāḥ syuḥ \| trișașthalābhopagatair asaumyaih kendratrikonopagataiś ca saumyaih | ratnāmbarasvarnayaśahsukhāptir nāso 'py ariștasya tanoś ca pușțih \| tunge śanir vā bhrgujo gurur vā śubhetthaśālì yavanād dhanāptim | balī kujo vittagato yaśo'rthatejāmnsy a kasmāc ca sukhāni dadyāt \|

maṇitthah |

sukhādhipah saukhyagato balișthaḥ saumyejyaśukraih sahito 'tha dṛsțaḥ| dadāti saukhyạ̣ vipulaṃ manojñām jāyām susaundaryaguñānvitām ca || muthahāyā upacaye sūryo vā dharan̄isutah | tasmin varșe śubham sarvam saphalam bhadradāyakam ||

2 vinaśyā] vināśyā B N G || sukhe] sukhaṃ K T M 4 vittadạ]] vittagaḥ G $\quad 5^{-14}$ lagne ... dadyāt] om. B N G 8 gajāśvā] gajāsvā K; gajākhā T 9 yadā] yayadā T 12 sukhāptir] scripsi; sukhāptiṃ K T M 14 akasmāc] akasyāc T 17 manojñāṃ] scripsi; manojñaṃ B N G K T M

1-2 guruh ... diśet] VT 4.2 $\quad 3^{-4}$ lagnādhipo ... vittadạ]] VT 4.1 $\quad 5^{-8}$ lagne ... ca] VT 4.45 9-10 yadā ... syuh] VT 4.7 11-12 tri ... puștịh] VT 4.6 13-14 tunge ... dadyāt] VT 4.8 16-17 sukhādhipah ... ca] VPh 29; HS 52, 100

3-4 lagnādhipo ... vittadah] G gives this stanza twice, the first time substituting nāśyārthasukhe diśet for the last $p \bar{a} d a$, with a subsequent correction of nāśy $\bar{a}$ - to vināsyā-; the second time reading -vittagah for -vittadah. 
[If] Jupiter is in an angle or a trine, unaspected by malefics and aspected by benefics, the misfortune [indicated by] the moon, the ascendant and the inthih $\bar{a}$ vanishes, and one should predict wealth and happiness.

When the ruler of the ascendant, endowed with strength, is aspected by or joined to benefics [while] occupying an angle or a trine, it will destroy misfortune and give happiness and wealth.

[If] the ruler of the descendant is in the ascendant and Jupiter occupies the ascendant unaspected by malefics and aspected by friendly benefics, it destroys misfortune, and one should predict the attainment of wealth, renown and happiness in its own period, and the favour of the king. [If] the rulers of the ninth and second houses are endowed with strength, unaspected by malefics and occupying the ascendant, then there will be dominion complete with elephants, horses, garments and ornaments, annihilation of misfortune, and incomparable renown.

When the ruler of the munthaha, the ruler of the ascendant [of the year], or the ruler of the ascendant of the nativity is strong, and they occupy angles, trines, the eleventh or the second house, they will give gain of happiness, wealth, gold and garments.

By malefics occupying the third, sixth, and eleventh houses, and benefics occupying angles and trines, there is attainment of ornaments, garments, gold, renown and happiness, annihilation of misfortune, and bodily well-being.

Saturn or Venus or Jupiter in its exaltation, forming an itthaśāla with a benefic, will give gain of wealth from a Yavana; and Mars, strong and placed in the second house, sudden renown, wealth, vigour and pleasures.

[And] Maṇittha [says in Varșaphala 29]:

The ruler of the fourth house placed in the fourth house in great strength, joined to or aspected by Mercury, Jupiter and Venus, gives abundant happiness and a charming wife endowed with great beauty and virtue. [If] the sun or Mars is in an increasing place from the muthaha $\bar{a}$, in that year everything is good, fruitful and fortunate. ${ }^{84}$

84 The increasing places (upacaya), a concept from pre-Islamic Indian astrology, are houses $3,6,10$ and 11 . 
așțamalagnāpavādaḥ saṃhitāyām |

jhașakulīravrșālimrgāanganā jananarāśivilagnagṛāșțagāḥ| subhaphalā bhṛuṇā kathitās tayor adhipatī suhṛdau hi parasparam ||

yādavah |

yadi śubhā bhavakanțakakonagā yad athavāngapatir balikendragaḥ|

harati rișțagaṇam gaṇapārcanam tanubhṛtāṃ namatām iva vighnajam || yadi khalo 'bdatanoḥ śaśino 'thavā triripuläbhagatah sabalah śubhaih| balibhir ìkșitayuk ca tathā hared aśubham āmayam ämayajam malam \| tanupatir yadi vābdapatih śubhạ śubhavilokitayug yadi kendragaḥ $\mid$ bhrgusuto 'tha hared aśubham bahu kulam aśilam ivāryajanaị stutam | balini saumyakhage 'py abale 'śubhe bhavati sarvaśubham tanudhārinām \| vilasadamalatejāś candramāh kendravartī sphuradamalakaraughaih saumyakhețaiś ca yugdrk| mrtisahamam avīryam virryayuktaś ca jivo harati maraṇakälam yogivat siddhabandhah $\|$

2 -ānganā] -āngavā $\mathrm{K} \|$ janana] janama N || āșțagāḥ] āșțamāḥ G 5 śubhā bhava] śubhabhāva G; śubhāśubha M 6 gaṇapārcanaṃ] gaṇayārcana N \| vighnajam] vidhūjaṃ G 7 gataḥ] gavaḥ K T 8 yuk ca tathā] yutkathavā B N K \| āmayam āmayajaṃ malam] äbhayamanggalam K \| malam] mam M 9 śubhah śubha] śubhāśubha K T M 10 ivāryajanaiḥ stutam] aśīlam ivārjitam B N; ivārjajanaistutam G 11 dhārinām] dhāriṇaṃ G 13 karaughaih] kasaṃghaih K T 14 sahamam] saham K M \| yuktaś] scripsi; yuktaṃ B N G; yuktañ K T M || jīvo] scripsi; jīvaṃ B N G K T M 15 kālaṃ] pālaṃ M \| yogivat] yogavit G || bandhah] vaṃdyah N K T M

$5^{-15}$ yadi ... bandhah] TYS 9.14-17

2-3 jhașa ... parasparam] VāP (s.v. upayama) cites the same stanza without attribution. 
An exception to [the rule of] the eighth [house becoming the] ascendant [is stated] in the Samhitā: $: 55$

Pisces, Cancer, Taurus, Scorpio, Capricorn and Virgo occupying the eighth [place] from the domicile on the ascendant [or] the sign [of the moon] in the nativity are declared by Bhrgu to give good results, for the rulers of those two [domiciles] are mutual friends. ${ }^{86}$

[And] Yādava [says in Tājikayogasudhānidhi 9.14-17]:

If benefics occupy the eleventh house, angles and trines, or if the ruler of the ascendant is strong and occupying an angle, it removes a host of misfortunes, just as the worship of Ganeśa [removes misfortunes] arising from hindrances for those men who bow down to him. ${ }^{87}$

If a strong malefic occupies the third, sixth or eleventh house from the ascendant of the year or from the moon, aspected by or joined to strong benefics, it will remove evil just as crêpe ginger [removes] impurities caused by disease. ${ }^{88}$

If the benefic ruler of the ascendant or ruler of the year is aspected by or joined to benefics and Venus occupies an angle, it will remove much evil, just as an uncultured family [improves its standing] when praised by noble men. When a benefic planet is strong while a malefic is weak, all happiness befalls men.

The moon dwelling in an angle, resplendent with pure light and joined to or aspected by benefic planets shining forth with a flood of pure rays, the sahama of death without strength and Jupiter ${ }^{89}$ endowed with strength, dispel the [imminent] time of death like a yogin who has mastered the locks. ${ }^{90}$

85 Although it is not clear which saṃhitā Balabhadra is referring to (the Kaśyapa-, Nārada-, and Vasișțasaṃhitās referenced earlier do not seem to contain this stanza, nor does Varāhamihira's Bṛhatsaṃhitā), it is unlikely to be a Tājika work. Most likely the rule cited occurs in the context of catarchic (muhürta) astrology.

86 The rulers of the following pairs of signs are meant: Leo and Pisces; Sagittarius and Cancer; Libra and Taurus; Aries and Scorpio; Gemini and Capricorn; Aquarius and Virgo.

87 The word gana 'host' recurs in the name Ganapa or Ganeśa 'Lord of the hosts'.

88 A pun on the word amaya, which can mean 'illness' but is also a name for the medicinal plant referred to.

89 Or, possibly, '[the sahama of] life'.

9o Although the reading is syntactically awkward, this is the most likely intended meaning. The 'locks' (bandha) are physical techniques that form part of the hațayoga tradition. 
hillāje |

jīve vilagne tanupa ha sa eva trairāśikeśo na bhavaty ariștam | mandas tanoh kendragatạ̣ sa eva musallaheśas tv aśubham vinaśyet \|| trairāsíipo 'stakhalavakraviyug balạ̈̂hyạ̣ satsthānagah khalaviyuk sitaguś ca jivvet

sukras tu kendrarahito yadi paśyatījyam

kendrānugam sakalam eti layam tv ariștam \|

candrarāŝsiśvaro lagnarāśipaś ca khalair viyuk|

riștam tadā layam yāti yathā vyādhiḥ sadaușadhaih $\|$

atra viśeșa uktas tājikamuktāvalyām |

șașthāṣtamadvādaśaturyasaṃsthā pāpānvitā krūranirīkṣitenthā| tadīsvaras tadvad athärkalupto varșeśvaro randhraripuvyayasthah $\|$ astamgato lagnapatiś ca tadvat sāmānyato 'nye 'pi vināśasamsthāh | tathābdalagnāt tripatākacakre viddhah śaśí janmapatiś ca randhre \| parājitā varșapajanmalagnavarșāngamunthāpatayas tathaiva | astamgatā jōvitapunyadehanāthā ime riștakarā hi yogāh $\|$ ato 'nyathā riștaharāh khacarā munibhị̣ smṛtāḥ| riștakartrgrahānāịn ca vīryam ekatra kārayet $\|$ tadvac ca riștaharț̣nām sthāpayec ca prthag balam | tatra riștabale yojye mintirogabale punah $\|$ dehānigapuṇyajī ānām balaṃ tadbhañgakrdbalam | iștakaștabalam kṣepyam rișțārișțabale tathā $\|$

1 hillāje] hillājah K T M 4 trairāśipo] trairāśiko M || 'sta] 'staḥ G || khalavakraviyug] khalevayug B N $\|$ balāḍhyaḥ] valādyaḥ $\mathrm{N} 5$ viyuk] viyuka $\mathrm{G} \|$ sitaguś] śitaguruś B N; -taguś G || jivet] jìve N p.c. 11 -enthā] -eṃtthihā B N; -enthihā K T M 12 lupto] luso N 18 grahāṇāṃ] grahāsyam K $\quad 19$ tadvac ca] tadūcca T 20 tatra] tatrā K $\|$ ṃrti] smṛti B 21 bhanga] bhaga M || balam] vate G; valaḥ K T; balah M

11-12 șașțhā- ... vyayasthah] TM $72 \quad$ 13-14 astaṃgato ... randhre] TM 71 $\quad 15^{-540.4}$ parājitā ... hi] TM $73-78$

17-542.17 rișta ... lābhah] The digitized images of $\mathrm{N}$ corresponding to this part of the text are illegible. 
[And] in the Hillāja[tājika it is said]:91

If Jupiter is in the ascendant and is itself the ruler of the ascendant [or] the ruler of the triplicity, no misfortune occurs. [If] Saturn occupies an angle from the ascendant [but] is itself the ruler of the musallaha, the evil will perish. [If] the ruler of the triplicity is free of [heliacal] setting, malefics, and retrogression, and endowed with strength, and the moon occupies a good place free from the malefics, [the native] will live. And if Venus, deprived of [a position in] an angle, aspects Jupiter found in an angle, all misfortune vanishes. If the ruler of the sign of the moon and the ruler of the sign on the ascendant are free from the malefics, then misfortune vanishes, as an illness [vanishes] by [the use of] good medicines.

Concerning this, a special rule is stated in Tãjikamuktāvali [72, 71, 73-78]:

The inthiha occupying the sixth, eighth, twelfth or fourth [house] joined to malefics [or] aspected by malefics; its ruler likewise, or robbed [of its light] by the sun; the ruler of the year placed in the eighth, sixth or twelfth house;

- the ruler of the ascendant [heliacally] set, or likewise other [planets] in general, occupying the eighth house; similarly, the moon intersected in the Three-flag diagram [calculated] from the ascendant of the year, and the ruler of the nativity in the eighth house;

- similarly too, the ruler of the year and the rulers of the ascendant of the nativity, the ascendant of the year, and the munthaha vanquished; and the rulers of the [sahamas of] life, fortune and the body [heliacally] set: these are configurations causing misfortune. [Configurations] contrary to these are considered by sages to remove misfortune. One should set down the power of the planets causing misfortune in one place, and likewise draw up the strength of those removing misfortune separately. The strength of [the sahamas of] death and illness should be added to that strength of misfortune, and then the strength of [the sahamas of] body, limbs, fortune and life [and] the strength of [the planets] counteracting them [should likewise be added]. Similarly, the strength for good and evil should be added to the strength

91 Text witnesses K T M read hilläjah in the nominative, implying the name of an author, rather than hilläje in the locative, implying the (partial) title of a work. 
tayor antarato dhìmān rișțam tadbhañgam ādiśet |

sāmye rișțasamam kleśam dharmād riștam layam vrajet ||

rișțakrdgrahadaśāntare yadāntardaśādhiripupāpino bhavet |

tatra mrtyum api niścayam vadej jātakāyuravasāna eva hi $\|$

ity arișṭabhangavicāraḥ ||

atha rājayogavicāraḥ | uktaṃ ca sudhānidhau |

nrpāspadam sarvajanābhimrgyam

labhyam ca tad bhāgyavaśena pumbhị̣ |

tal labhyate khețakrtais tu yogais

tān atra yogān kathayāmi kāmśsit \|

turyeśo 'mbugato balī baliśubhair yuktekșito rājyadah

kendrāptitrisutānkagah suragurur janmāñgapo veśmagah |

yoge 'smin dvitaye 'pi väjivilasatkumbhindrasenam nrrpam

tam kuryāt samadadvișaḍajagaṇe śārdūlavikrịditam ||

yuvatidhāmapatis tanugo balī guruyutekșitamūrtir ihodbhavām |

vividhabhogayutāṃ nrpasampadạ̣ paridadāti dadāti manorathān $\|$

meșūraṇe svoccagatah patanga h karkodaye vākpatir indur arthe | sūryetthaśálas tu bhaven nrpālah samudramudrāinkitabhümipālah \|

\footnotetext{
1 antarato] aṃtar adhah B; aṃtarajo K T M 2 sāmye] saumye G; saumyai K T M || rișța] riștam K M || dharmād rișțaṃ] dharmārișțam B; dharmād ișțam K M; dharmādișțham T 3 daśādhiripu] ddaśādhipa B; ddaśāvidhiripu G \|| pāpino] yāyino G 4 avasāna] avaśātu K T 5 arișta] ari K T 6 ca] om. G 12 āpti] āptiḥ G T 13 dvitaye] dvitīye B \| kumbhīndra] kuṃbheṃdra M 14 taṃ] tat B K T M \|| kuryāt] kuryātat kuryāt B \| gaṇe] -ṇo G; gaṇo T 15 -bhavām] -bhavam B K T M 16 yutāṃ] yutaṃ B K T M \| sampadaṃ] saṃpadā K T M || manorathān] manorathaṃ K T M 18 nụpālaḥ] navālaḥ B
}

7-542.14 ṇ̣pāspadaṃ ... jālaih] TYS 10.1-10 
of misfortune or lack of misfortune. From the difference between the two, a wise [astrologer] should predict misfortune or its cancellation. If [the indications for both are] equal, [he should predict] suffering equal to [fatal] misfortune, [or that] the misfortune will vanish by [acts of] piety. When the subperiod of a great enemy [that is also a] malefic should occur within the period of a planet causing misfortune, then one should predict certain death [if the time falls] at the end of the life-span [indicated by] the nativity. ${ }^{92}$

This concludes the consideration of cancellation of misfortune.

\subsection{Configurations for Dominion}

Next, the consideration of configurations for dominion; and it is said in [Tājikayoga]sudhānidhi [10.1-10]:

The royal throne is sought after by all men, and men may attain it by the force of destiny. It is attained by the configurations formed by the planets: here I describe some of those configurations.

The ruler of the fourth [house] strong in the fourth house, joined to or aspected by strong benefics, gives kingship. Jupiter placed in an angle, the third, fifth, or ninth house, [and] the ruler of the ascendant of the nativity placed in the fourth house: in this double configuration, it makes that [native] a king with an army of mighty elephants and shining with horses, playing like a tiger amid a dozen rutting elephants. ${ }^{93}$

The ruler of the seventh house placed in the ascendant, strong and with its body joined to or beheld by Jupiter, bestows the royal splendour born of this [world] along with numerous pleasures: it fulfils one's desires.

The sun occupying its exaltation in the midheaven, Jupiter in a Cancer ascendant, the moon in the second house in an itthaśâla with the sun: [with this configuration the native] will become a king ruling the land [to where it is] sealed by the ocean..$^{94}$

92 Or, possibly, '[indicated by the science of] genethlialogy' or even '[indicated by the Brhaj]jātaka'.

93 The subject of this sentence ('it') is not clear. The image alludes to the name of the metre employed: śärdūlavikrīdita 'tiger's play'.

94 Or oceans. The idea may be that of a king ruling (part of) the Indian subcontinent from its eastern to its western coast. 
karkodaye vākpatir indur āro 'je müthaślì nrpatị̣ svabhe 'rkaḥ| yasya prasādād arisundarịnām samudrasaṃdarśanakautukam syāt \| niśeśasūryau sitavākpatī ca krtetthaśālau patitānyabhasthau| vīryānvitau sto yadi bhūpa urvīm praśāsti sacchattrayaśo'vatamsah \| varșeśvaro lābhagato 'rkajo 'rko meșūrane candrakrtetthaśálaḥ| samudrasīmānam ilām purìvat sampālayet pālitaśatrubālah \| vīryaśālibhrgujetthaśālini sādhikārapadalābham arkaje | mlecchamaṇ dalavimardanakșamo bhüpatir gajarathoddhato raṇe \| sarve subhāḥ kendragatās trilābhāristhāh khalā vīryayutā nrpah syāt | vātocchaladgāngataramgaśobhāharasphuraccāmaravījyamānạ̣ \| pañcādhikāripatibhir mitha itthaśälaih kendrasthitair balayutair nrpatih pidhatte | yah svapratāpatulitam hi rușeva sūryam prenkhatturamgamarathotthitarenujālaị $\|$

lagne 'mbareśạ śubhakhecaraś cec chaśānikalagnādhipatī nabhaḥsthau | svavīryayuktau śubhavīkșitau sto varșe tadā syāt khalu rājyaläbhạ̣ \| lagnādhināthena himāṃśunā vā yadītthaśālaṃ kurute 'mbareśạ | śubhah svatungādigato 'mbaram ca paśyet tadā syāt khalu räjyaläbhah \|

1 indur āro 'je] indurāje B; indurājye sa K T M 4 vīryānvitau sto] vīryānvitāste M || sto] stau B; ste K T \| urvīṃ] ūrvyā K T; ūrvyāṃ M || sacchattra] nakṣatra B K M 6 sīmānam ilāṃ] sāmānam ilāṃ G; sīmāmam ilāṃ K T; sīmāṃ mahilāṃ M 7 lābham arkaje] lābhakarmaje B K T M 10 vātocchalad] vātocchalād B; vātoddalād G 12 nụpatị pidhatte] nụpatir vidhatte B K T M 13 yaḥ sva] yaḥ B; yasya K T M 14 preńkhat] premṣa G; premuvat $\mathrm{K}$ \| turaṃgama] turaṃga $\mathrm{G} \quad 16$ lagne 'mbareśạ] lagneśvareśaś K M; lagneśvaresaś $\mathrm{T} \quad 17$ khalu] khanu G 19 sva] sa B || 'mbaraṃ] ṃvare B \|| paśyet] taśye $\mathrm{K}$ \| syāt] syā G

18-19 lagnādhi ... lābhaḥ] B accidentally gives this stanza twice. The second occurrence has been bracketed, seemingly in the same hand.

95 Presumably with a view to actually crossing the ocean and enjoying the king's 'favours'. The fact that the enemy is pictured as living across the ocean agrees with the assumption that Yādavasūri was a resident of Gujarat; cf. the Introduction.

96 Ruinous signs are presumably those falling in the evil houses (6, 8 and 12).

97 The parasol, especially if white, is a classical emblem of royal power in India. Text witnesses B K M read 'asterism' for 'parasol'.

98 Again, this is the most likely intended meaning of a syntactically awkward construction. In Indian cosmology, Ilā is the central and highest part of the central continent Jambudvīpa.

99 Or, possibly, 'the children of his enemies'. The implication in either case is that the (adult male) enemies have been killed. 
Jupiter [and] the moon in a Cancer ascendant, Mars in Aries in a mutthaśila [with the moon], the sun in its domicile: [with this configuration the native becomes] a king on account of whose favour the women of the enemy will eagerly wish to behold the ocean. ${ }^{95}$ If the moon and the sun, and Venus and Jupiter, [respectively], form an itthaśa $a$ la, occupying signs that are not ruinous, ${ }^{96}$ and are endowed with strength, [the native becomes] a king [who] rules the earth, adorned with the spendour of [royal] parasols. ${ }^{97}$

[If] the ruler of the year is Saturn placed in the eleventh house and the sun is in the midheaven forming an itthaśa la with the moon, [the native] will govern [the land up to] the ocean boundary like the city of Ilā, ${ }^{98}$ guarding the women of his enemies. ${ }^{99}$

If Saturn has an itthaśāla with Venus endowed with strength, along with attaining a position of authority, [the native becomes] capable of vanquishing foreign troops, a king raised up on an elephant chariot in battle. ${ }^{100}$

[If] all the benefics occupy angles and the malefics are placed in the third, eleventh and sixth houses, endowed with strength, [the native] will become a king fanned with sparkling yak-tail whisks evoking the brilliance of Ganges waves stirred up by the wind. ${ }^{101}$

By itthaśa las between the five rulers in authority, occupying angles and endowed with strength, [the native becomes] a king who darkens the sun - equal in fury, as it were, to his own prowess - by the clouds of dust thrown up by the jolting of his horse-[drawn war] chariots. ${ }^{102}$

[And] in the Uttaratantra [it is said]:

If the ruler of the tenth house is a benefic planet in the ascendant, and the moon and the ruler of the ascendant are placed in the midheaven, endowed with their respective strengths and aspected by benefics, in that year [the native] will surely gain dominion.

If the benefic ruler of the tenth house, occupying its exaltation and so on, makes an itthaśāla with the ruler of the ascendant or with the moon and aspects the tenth house, then [the native] will surely gain dominion.

100 Another allusion to the name of the metre employed: rathoddhata ' 'raised up in a chariot'.

101 The (white) yak-tail fan is another emblem of royal power.

102 Presumably the sun's 'fury' refers to its reddish glow when darkened by dust, sand, etc. 
himāṃśukarmādhipalagnanāthā meșūranasthāh śubhavīkṣitāś ca| svoccādigāhn syuḥ śubhakhecarāś cet tadā prakuryur dhruvarājyalābham \|| harșasthite karmapatau subhagrahe svatungarāsyyadigate tathodite | śubhekșite kendradhanatrikonage räjyasya lābho 'sti śubhair vilagnagaih \|| lagneśvarah svarkșagato vilagne svatunganāthena nijoccagena |

drșțas tadā tatra abhișțarājyalābho bhaved bhümipate h krameṇa \| svoccasthito lagnagatah śubhagrahah śeșais trikonāyagatair balānvitaịn| acintitā rājapadāptir unnatị̣ syād alpikā svarkșagṛādisamsthitaị ॥ minodaye bhārgavajīvasamyute lābhe kuje rājyapadāptim ādiśet | vrșodaye saumyahimāṃśubhārgavaị kendre gurau syuh khalu räjyasampadah $\|$ śubhetthaśälo 'mbarapo vilagne räjyapradah svoccagrhādisamsthaḥ| lagneśvare svarkșagate vilagne svocce kuje syāt khalu räjyalābhah \|| kendre himāṃśuh svagrhe svatunge vāpītthaśâlam kurute khapena | lagnādhipenātha catuștayastho varșe tadā syāt khalu räjyalābhậ $\|$ kendrasthite śitakare balạ̈̂hye śubhair yute krūravivarjite ca | suddhe 'pi vā syāt khalu räjyaläbhaś candre 'bale nīcagate na räjyam \|

maṇitthah |

2 gāḥ syuḥ] gasthāḥ B N; bhasthāś K T M $\quad 5$ vilagne] vilagnage G 8 saṃsthitaih] saṃsthaih B N KTM 15 vāpī-] vīrye- B N KTM || khapena] svapena M 16 lagnādhipenātha] lagnādhipo nātha M 17 balāḍhye] valādye B N

103 The astrological configuration described here may be understood in two ways. If the 'exaltation ruler' is the planet whose exaltation falls in the rising sign itself, then the configuration can only be a conjunction and not an aspect proper: for instance, Cancer rising with the moon in it, and with Jupiter, whose exaltation is Cancer, present in the same sign. But the phrasing seems rather to suggest that the 'exaltation ruler' should be understood as the domicile ruler of the sign where the first planet would be exalted: for instance, Cancer rising with the moon in it, and with Venus, ruler of Taurus (where the moon would be exalted), placed in its own exaltation Pisces, from where it would aspect the moon by a trine. 
If the moon, the ruler of the tenth house and the ruler of the ascendant occupy the midheaven, aspected by benefics and occupying their exaltations and so on, and are [themselves] benefic planets, then they will being about certain gain of dominion.

If the ruler of the tenth house is a benefic planet in its place of joy, occupying its sign of exaltation and so on, and likewise [heliacally] risen, aspected by benefics, and placed in an angle, the second house, or a trine, while benefics occupy the ascendant, there is gain of dominion.

[If] the ruler of the ascendant occupies its domicile in the ascendant, aspected by its exaltation ruler placed in its own exaltation, then [the native] will gradually obtain the desired dominion from the king. ${ }^{103}$

[If] a benefic planet occupies the ascendant in its exaltation, with the others occupying trines or the eleventh house, endowed with strength, there will be unexpected attainment of royal dignity; a lesser elevation with [the other planets] occupying the signs of their domiciles and so on.

If a Pisces ascendant is joined by Venus and Jupiter, with Mars in the eleventh house, one should predict attainment of royal dignity. Indeed, by Mercury, the moon and Venus [being placed] in a Taurus ascendant while Jupiter is in an angle, there will be the blessings of dominion.

The ruler of the tenth house occupying its exaltation, domicile and so on in the ascendant, in itthaśäla with a benefic, bestows dominion. If the ruler of the ascendant occupies its domicile in the ascendant while Mars is in its exaltation, [the native] will surely gain dominion.

[If] the moon in an angle in its domicile or its exaltation makes an itthaśăla with the ruler of the tenth house, ${ }^{104}$ or with the ruler of the ascendant [while] occupying an angle, ${ }^{105}$ in that year [the native] will surely gain dominion.

If the moon endowed with strength occupies an angle, joined to benefics and free of malefics, or waxing, [the native] will surely gain dominion; [but] if the moon is weak [or] placed in its fall, there is no dominion.

[And] Manittha [says in Varșaphala 28, 33, 48, 34, 36, 49, 47, 37, 35, 42, 41]:

104 Text witness M reads 'with its own ruler'.

105 Text witness $\mathrm{M}$ reads '[if] the ruler of the ascendant occupies an angle from its ruler'. 
vācaspatir lagnagatas tritīyo janmādhināthah sukhago 'tra yasya | sa vairivrnndam parijitya bhunkte balam gajāntam vipulām ca lakșmìm \| jāmitranāthe tanubhāvayāte lagne gurau mitraśubhaiś ca drșțe | krürair adrșțe dhanadhānyayukto bhaven narah śakrasamo balena \| dharmādhināthe sabale 'rthanāthe yute śubhair lagnagatair adrșțe | krūrair gajāntām vipulām ca lakșmīm bhunakti jantuh śubhakarmayuktah $\|$ saumyagrahaih kanțakagair asaumyais trișașthaläbhopagatair vilagnāt | kìrtiprabhāputradhanāni ratnapravālavastrādisamastaläbham \| nijāmśakasthe tridaśejyapüjye daityādhipe svoccam upāgate ca | nijāmśakasthe rajaniśaputre bhaven manusyo manujādhināthaḥ $\|$ yadītthaśālo guruśukrasaumyaị krtas tadā rājyabhavo hi lābhah | svoccasthitais tai racito yadāsau balena śakrapratimo manusyạ̣ \| dharme ratih kāmcanaläbhayuktā prītih svavarge dhanadhānyayuktā | balī ca bhaumo dhanabhāvasaṃstho bhaved akasmād atulam ca tejah $\|$ niśädhināthena krte kabüle devādhipejye tanukanțakasthe | ratnāśvalābham kurute tadānīm yaśaś ca lakṣmīm atulām karoti $\|$ yadītthaśālo ravito 'sti saumyaị̣ krūrais trișașthāyagataị sahaiva | vïitya sarvān api vairivrndān bhunakti räjyam vipulaiś ca bhogaih \|

1 sukhago] sutago K M $\quad 2$ parijitya] parihṛtya B N K T M $\quad 3$ jāmitra] yāmitra B G 4 adṛsțe] adṛsțo $\mathrm{G} \|$ śakra] śukra B N $\quad 5$ 'rtha] rkșa B || yute] yukte $G \quad 9$ sthe] sthū G 12 sthitais tai] sthitaisau $\mathrm{K} \|$ racito] racitau B N || śakra] śukra B N || pratimo] pramito B N G 13 yuktā̄] yuktāḥ B; yuktaḥ N K T M \| yuktā²] yuktaḥ B N K T M 15 tanu] scripsi; na tu B N K T M; nanu G 17 saumyaih] saumyah K T M

1-2 vācaspatir ... lakșmīm] $\mathrm{VPh} 28$; $\mathrm{HS}_{51}, 288 \quad 3-4$ jāmitra ... balena] $\mathrm{VPh} 33 \quad 7-8$ saumya ... lābham] VPh 48; HS 70 9-10 nijā- ... -nāthah] VPh 34; HS 56 11-12 yadī ... manuṣyah] ] $\mathrm{VPh} 36$; HS $5^{8} \quad$ 13-14 dharme ... tejạ. $]$ VPh 49; HS 71 15-16 niśā- ... karoti] VPh 47; HS 69 17-18 yadī ... bhogaih] $\mathrm{VPh}$ 37; HS 59

15 tanu] The emendation is supported by MS VPh. 
He who has Jupiter occupying the ascendant [or placed in] the third, and the ruler of the nativity placed in the fourth house, ${ }^{106}$ vanquishes a host of enemies and commands an army equipped with elephants, and abundant riches.

If the ruler of the seventh house occupies the first house and Jupiter is in the ascendant, aspected by friends and benefics and unaspected by malefics, a man will be endowed with wealth and grains and equal Indra in strength.

If the ruler of the ninth house is strong and the ruler of the second house is joined to benefics occupying the ascendant but unaspected by malefics, a man performs good deeds and enjoys abundant riches including elephants. ${ }^{107}$

By benefic planets placed in the angles and malefics occupying the third, sixth and eleventh houses from the ascendant, [he enjoys] renown, splendour, children and wealth, and the acquisition of all things such as jewels, coral and clothes.

If Jupiter is placed in its own division ${ }^{108}$ and Venus occupies its exaltation while Mercury is placed in its own division, a man becomes a ruler of men.

If an itthaśála is formed by Jupiter, Venus and Mercury, then there is gain produced by dominion. When that [configuration] is formed by those [planets] occupying their exaltations, a man equals Indra in strength.

Love of piety along with gain of gold, delight in one's own [family] circle along with wealth and grains, and unequalled vigour, will come about unexpectedly [if] a strong Mars occupies the second house.

If the moon forms a kambüla with Jupiter placed in an angle from the ascendant, then it makes gain of jewels and horses; it causes renown and unequalled riches.

If there is an itthaśäla of the sun with the benefics, [and] with the malefics occupying the third, sixth and eleventh houses, [the native] vanquishes all enemy hosts and enjoys dominion with abundant pleasures.

106 Text witnesses K M read 'fifth house'.

107 This verse is not attested in available independent witnesses of the Varșaphala.

108 The word used here is am śa $[k a]$, which may mean 'degree' but is also frequently used in Indian astrology as a shorthand for other divisions of a zodiacal sign, particularly the ninth-part. Similar expressions recur below, using the words bhäga (which likewise can mean 'degree'), varga (which refers to astrological divisions but not to degrees) and, once, hadd̄a 'terms'. 
saumyenduśukrā nijahaddasaṃsthāh

sūryāramandās trikhalābhasaṃsthāh |

tadā dhanam vā bahulaprabhāvān

bhunakti śakrapratimo balena \|

dvau mūsarihphau yadi śukrasaumyau gurus trtī̄opagato 'sti yasya |

muktāyaśorājyaphalam vidhatte hastyaśvanișiẹditavairivrndam \|

yadā mutheśo nijabhāgavartī svoccaṃ gato mitraśubhaiś ca dṛ̦țah | dadāti lakṣmīm gajaratnahemapravālakādyām satatam narebhyạ \| trirāsinātho yadi bhūmiputrah svatungabhāge nijabhāgago vā| lagnatrikonāyagato dadāti mahāsukham sarvabalopapannam || svoccam gate devapurohite ca trirāsināthe nijavargasamsthe | parasparālokanam atra yāte dadāti putrān vipulāṃ ca lakṣmìm || caturthasauriryadi somaputrakambūlavartīyadi pañcamāmśse | mahābalam prāpayate sa khețo mitrāgamaṃ kāryavilāsayuktam \| mitrasya gehe yadi bhümiputro grahaih sthitaih svoccagrhe kabülī| dadāti rājyam vipulaṃ manojñām nārị̣̄ dhanam vājigajādilābham || yadīndusaumyejyasurāripūjyāḥ svoccam gatāh svāṃśagatā yadi syuḥ| lagnāt trikendrāyagatāh svamitrair drșțāś ca yuktā nijavīryayuktāh || gajāśvaratnāmbaradeśalābham strīputralābham vividham ca saukhyam | yacchanti khețāh paramardanam ca kurvanti sarvam balino narānām \| bhāgyādhipaḥ svoccam upāgato balī ravīnduvācaspatibhir nirīkșitaḥ| bhāgyodayah syād dhanadhānyalābho nṛaprasādo niyatam narānām || yadārkaputro balavān svatungasamstho 'tha tunge bhrgujo balādhyah | yadā tadā mlecchajanaprasādād bhunakti rājyaṃ vipulām ca lakșmīm \|

1 śukrā] nakrā K M $\quad 2$ saṃsthāḥ] saṃsthaih N $\quad 3$ vā] yā N || prabhāvān] prabhāvād M 4 pratimo] pramito B NG 6 muktā] bhuktvā KT M 7 yadā mutheśo] yadāvanīso M 8 ādyāṃ] āḍhyāṃ G M; āḍhyaṃ K T 10 mahā] mahī G; mahīm T 13 putra] scripsi; putrah B N; putro G; putreș K T; putraiḥ M 14 prāpayate sa khețo] bhūridhanaṃ ca dhatte KT M \| khețo] khețe B N 18 yuktāḥ] muktāḥ G 19 gajā] rgegajā N 20 para] mara G \| kurvanti sarvaṃ] kurvam N; kurvanti sarve K T 22 bhāgyodayah] bhāgyodayam K T 23 'tha] pya K T M

1-4 saumye ... balena] VPh 35; HS 57; cf. HS $99 \quad 5^{-6}$ dvau ... vṛndam] VPh 42; HS $64 \quad 23^{-24}$ yadārka ... lakșmīm] VPh 41; HS 63

13 putra] Evidence from independent witnesses of the $\mathrm{VPh}$ is equally inconclusive. An alternative emendation with little difference in meaning would be putre.

109 The meaning of this term is not clear. As the kambüla is a configuration involving the five dignities, the fifth-part may conceivably refer to the terms or haddā, of which there are five to a zodiacal sign. 
[If] Mercury, the moon and Venus occupy their own haddās, and the sun, Mars and Saturn occupy the third, tenth and eleventh houses, then [the native] enjoys wealth or manifold powers, equalling Indra in strength.

If the two [planets] Venus and Mercury are in müsarihpha and Jupiter occupies the third [house] for someone, [that configuration] bestows pearls, renown and dominion as a result, and a host of enemies trampled by [the native's] horses and elephants.

When the ruler of the munthaha dwells in its own division, occupying its exaltation and aspected by friends and benefics, it always grants men riches such as elephants, jewels, gold and coral. If Mars as ruler of the triplicity is in its degree of exaltation or occupies its own division, occupying the ascendant, a trine, or the eleventh house, it grants great happiness accompanied by all [manner of] strength. If Jupiter occupies its exaltation and the ruler of the triplicity occupies its own division, having entered into mutual aspect, it gives children and abundant riches. If Saturn [occupying] the fourth [house] forms a kambüla with Mercury in the fifth-part, ${ }^{109}$ that planet makes [the native] attain great strength ${ }^{110}$ and acquire friends along with pleasure in his work. If Mars is in the sign of a friend, having a kambüla with planets occupying their signs of exaltation, it gives extensive dominion, a charming woman, wealth, and gain of horses, elephants and so on. If the moon, Mercury, Jupiter and Venus occupy their exaltations and their own divisions while occupying the third, angles, or the eleventh house from the ascendant, aspected by or joined to their friends and endowed with their own strengths, [those] planets bestow gain of elephants, horses, jewels, clothes and land, gain of wives and children, manifold happiness, and the destruction of enemies: [when] strong, they do everything for men. [If] the ruler of the ninth house occupies its exaltation, strong and aspected by the sun, the moon and Jupiter, there will surely be a dawning of good fortune for men, gain of wealth and grains, and royal favour. ${ }^{111}$

When Saturn is strong, occupying its exaltation, and when Venus is in its exaltation endowed with strength, then [the native] enjoys dominion and abundant riches by the favour of foreigners.

110 Text witnesses K T M read 'it gives copious wealth'.

111 The verses in this paragraph are not attested in available independent witnesses of the Varșaphala. 
varșatantre |

yadā savīryo muthahādhinātho lagnādhipo janmavilagnapo vā| kendratrikoṇāyadhanasthitās te sukhārthahemāmbaralābhadāḥ syuḥ \| tunge śanir vā bhrgujo gurur vā śubhetthaśālād yavanād dhanāptim|

tājikasarvasvasāre |

syād ikkavāle khalu rājayogaḥ syād induvāre nṛparājyavicyutị̣| nrpātmajānām iha rājyalābho 'nyeșām pratișthā vasulabdhayaḥ syuḥ ||

tājikālaṃkāre 'pi |

janane jananetragocarāḥ khacarāḥ svasvagrhoccasamsthitāḥ| aribham pravihāya hāyane yadi te syuḥ sakalārthasiddhidāḥ || iti |

iti rājayogavicāraḥ \|

atha rājayogabhanggạ̣ | mạ̣itthạ̣ |

vyaye śaśāinko yadi tatra saurị̣ șașthe bhṛur hānikaraḥ samantāt | dhanāśvaratnādimahādbhutānām svacittavaikalyakaro hy akasmāt \| dharmādhipe vā vibale ca vittanāthe vilagne śubhadrștihīne | krūrair yute nāśam upaiti lakṣmīh susaṃcitā śakrasurakṣitāpi ||

2 yadā] sadā G $\|$ janmavilagnapo] janmani lagnapo K T $\quad 5$ sarvasva] om. G $\quad 6$ ikkavāle] ișkavālo G 8 'pi] om. G 9 janane] om. N \| jana] śubha B \| sva ${ }^{1}$ ] om. K 10 hāyane] hīyane N 11 iti ... vicārah] om. B N K T M 12 rājayoga] rāyojega N 13 bhṛgur] rguṃbhṛ N || hāni] hīna B N 14 vaikalya] kaikalya N || akasmāt] akasmā B

2-4 yadā ... dhanāptim] VT 4.7-8 13-14 vyaye ... akasmāt] VPh 50; HS 72 
[And] in Varșatantra [4.7-8 it is said]:

When the ruler of the munthaha $\bar{a}$, the ruler of the ascendant [of the year] or the ruler of the ascendant of the nativity is strong, and they occupy angles, trines, the eleventh or the second houses, they will give gain of happiness, goods, gold and clothes. By a benefic itthaśāla, Saturn or Venus or Jupiter in its exaltation [will give] gain of wealth from a Yavana.

[And] in the Täjikasarvasvasāra [it is said]:

In an ikkavāla, there may be a configuration for kingship; in an indu$\nu \bar{a} r a$, there may be a fall from royal power. Here, the children of a king may attain a kingdom; others, eminence and gain of property.

And in the Täjikālaṃkāra [it is said]:

If the planets that come within range of men's sight occupy their respective domiciles and exaltations in the nativity and avoid an inimical sign in [the revolution of] the year, they will grant the accomplishment of all objects.

This concludes the consideration of configurations for dominion.

\subsection{Cancellation of Dominion}

Next, the cancellation of configurations for dominion; [and] Manittha [says in Varșaphala 50]:

If the moon is in the twelfth house, Saturn there [too, and] Venus in the sixth, [that configuration] causes complete loss of wonderful things such as wealth, horses and jewels, and causes unexpected disturbance in one's mind.

Or if the ruler of the ninth house is weak and the ruler of the second house is in the ascendant without benefic aspects, joined to malefics, one's riches perish, however well accumulated and guarded by Indra himself. ${ }^{112}$

112 This latter verse is not attested in available independent witnesses of the Varșaphala. 


\section{tājikabhūṣaṇe |}

nīcasthitāé cāstamitāś ca pāpā nrpālayogam dalayanty alam te | khalāḥ kuvarge vibalāś ca saumyāh krtārgalāh syur narapālayogāh \|

tājikasāre 'pi |

nīcopagà vairigrhopayātāh pāpair yutā vāstagatā grahendrāḥ|

haranti rājyam vipulam narāṇām tadā sukhaṃ nālpataram hi varșe ||

duștavargopagāḥ pāpāḥ saumyāś ced balavarjitāḥ|

apakurvanti te rājyam kaștạ̣ kurvanti dehinām \|

yādavaḥ|

astamgatau nīcam upāgatau vā krūrārisampīditamūrtikau vā |

devejyaśukrau manujādhipatyam sukhārthalābham harato narānāām \|

sūtau vyomapatir grahah sa yadi cet tadvat padädhișțito

nīcam cāstam upāgatah śubhaharaḥ prokto 'bdaveśe budhaị̣|

saumyāś cet patitāśritāḥ khalakhagāḥ kendrāśritā vakrịno

nirvīryāyadi vā tadābdasamaye lakșmịh parikșīyate \|

janau vyaye 'nthā daśame ca varșe svasvāmisaumyekșaṇayogahīna $\mid$

sveśāridușțekșiyutā śriyaṃ haret tṛ̦ṇeva dhairyaṃ purușasya pūjyam || abdeśah padapo 'thavāstamayago nīcārigo vā bhavel lagneśena krtesarāphayutikạ̣ kheśo 'tha rātrišsvarạ̣ | kșinono nīcagatah śubhojjhitayutih sūryo 'pi dușțāśraȳ

rājyam nìtibalena viśritam iva kṣinnoti deham rujā $\|$

pañcādhikārișv api naiva kendratrikonaläbhakramago balīyān|

pare 'pi duștâśrayagā vivīryās tadā bhaved bhūrisukhārthanāśah \|

5 -yātāḥ] scripsi; -jātā B N K T M; -yātā G || yutā] yutāś G \|| vāsta] cāsta G 6 hi varṣe] viharṣe K M 8 apakurvanti] apākurvaṃti K M \| te] om. N 9 yādavah] om. K T M 10 krūrāri] krūrā N 12 tadvat] tadvad M || padādhișțhito] yadādhișțhitā B N; yadādhișţhito K M 13 upāgatah] ubāgatah N 16 janau] janai G || vyaye 'nthā] vyayetho G K T M \| daśame] daśamī B N G || hīnā] hīnah K T M 17 duṣțekṣiyutā] duṣțarkṣayuta K M; dușțarkṣayutā T || tṛ̣ṇeva] tṛ̦̣̣aiva K T M \|| purușasya pūjyam] puruṣapūjyaṃ G a.c.; purușaprapūjyam G p.c. $\quad 20$ gatah] yutaś K T M \| śubhojjhita] śubhohita B N K; śubho hita M \| yutiḥ] yutaḥ G 21 viśritam] viśratim B; vișram G; vistṛtam K T M || kṣinnoti] kṣinneti G; kṣinno T M \|| dehaṃ] deha B N; dehe K; videhe T M \| rujā] scripsi; rujaṃ B N G; rujam K T M 22 lābha] lābhạ̣ B N

2-3 nīca ... yogāḥ] TBh 9.1 $\quad$ 5-8 vairigṛhopa ... dehinām] TS 162-163 $\quad$ 10-23 astaṃ ... nāśaḥ] TYS 10.11-15 
[And] in Tājikabhüṣaṇa [9.1 it is said]:

Malefics occupying their fall and [heliacally] set are enough to break a configuration for dominion. [If] the malefics are in evil divisions and the benefics are weak, configurations for dominion are impeded.

And in Täjikasāra [162-163 it is said]:

Planets occupying their fall or resorting to inimical signs, joined to malefics or [heliacally] set, rob men of extensive dominion; in that year there is not the least happiness. If malefics occupy evil divisions and benefics are weak, they drive dominion away and make evil for men.

[And] Yādava [says in Tājikayogasudhānidhi 10.11-15]:

[Heliacally] set or occupying their fall, or their bodies afflicted by malefics and enemies, Jupiter and Venus rob men of authority over [other] men and of gain of happiness and wealth.

If the planet that rules the tenth house in the nativity is appointed to the same office in the revolution, [but] occupying its fall or [heliacally] set, the learned say that it removes the good [it signifies in that year]. If benefics occupy ruinous [places] and malefic planets occupy angles, retrograde or weak, then in that year, riches waste away.

The inthih $\bar{a}$ in the twelfth in the nativity and the tenth in [the revolution of] the year, bereft of the aspect or company of its ruler and the benefics [but] joined to the aspects of malefics inimical to its ruler, will carry off [the native's] prosperity, just as thirst [carries off] a man's admirable fortitude.

Should the ruler of the year or the ruler of the tenth house be [heliacally] set or placed in its fall or [the sign of] an enemy; the ruler of the tenth house form an isaräpha configuration with the ruler of the ascendant; the moon be waning, occupying its fall, and bereft of the company of benefics; or the sun occupy an evil [house], the [native's] domain is sundered, as it were, by the force of politics, and illness corrupts his body.

[If] the strongest among the five [planets] in authority is not placed in an angle, a trine, or the eleventh house, in order [of preference], and the others, weak, resort to evil places, then there will be much destruction of happiness and wealth. 
lagneśvare nīcapatītthaśāle rājyacyutir hìnadhiyā nrpasya |

khape svanīcādhipatītthaśále syād rāștram asya kșitipasya śūnyam \|

varṣatantre |

abdenthiheśādikhagāḥ khalaiś ced yutekșitā astaganīcagā vā | saumyā balonā nrpayogabhañgam tadā vaded vittasukhakșayaṃ ca \| ittham janmani varșe ca yogakartur balābalam | vimrśya kathayed räjayogam tadbhañgam eva ca \|

iti śrīmaddaivajñavaryapaṇḍitadāmodarātmajabalabhadraviracite hāyanaratne varṣeśādivicārādhyāyaḥ pañcamạ̣ ||5||

1 lagneśvare] lagneśare $\mathrm{N} \quad 1-2$ rājya ... -śāle] om. B N K M 1 hīna] nīna G 3 varṣatantre] om. G 4 abdenthiheśā] abdeṃthihāśā B N 5 saumyā] saumyo N $\|$ balonā] balonī N || kṣayaṃ] kṣayāṃś B N G 8 paṇ̣ita ... balabhadra] ${ }^{\circ}$ B 9 pañcamah] om. B N K M; samāptoyam || atha hāyanaratnasyottarārdham prārabhyate add. K; atha hāyanaratnasyottarārdhaprārambhaḥ add. T; samāptoyam add. M

4-5 abde- ... ca] VT 4.14 6-7 ittham ... ca] VT 4.13 
If the ruler of the ascendant has an itthaśa la with the ruler of its fall, the king falls from kingship due to poor thinking. If the ruler of the tenth house has an itthaśăla with the ruler of its own fall, the realm of that king will be deserted. ${ }^{113}$

[And] in Varșatantra [4.14, 13, it is said]:

If the planets [in authority], beginning with the rulers of the year and of the inthih $\bar{a}$, are joined to or aspected by malefics, [heliacally] set, or occupying their fall, and the benefics are weak, then one should predict cancellation of configurations for dominion and the loss of wealth and happiness.

Considering thus the strength and weakness of [the planet] making a configuration, one should declare a configuration for dominion or its cancellation.

In the Hāyanaratna composed by Balabhadra, son of the learned Dāmodara, foremost of astrologers, this concludes the fifth chapter: the judgement of the ruler of the year and so on.

113 This verse is not attested in available independent witnesses of the Tajikayogasudhānidhi. 